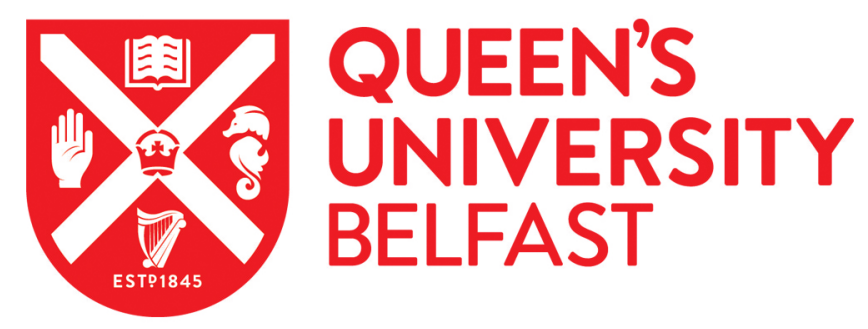

\title{
How Much Does Birth Weight Matter for Child Health in Developing Countries? Estimates from Siblings and Twins
}

McGovern, M. (2019). How Much Does Birth Weight Matter for Child Health in Developing Countries? Estimates from Siblings and Twins. Health Economics, 28(1), 3-22. https://doi.org/10.1002/hec.3823

\author{
Published in: \\ Health Economics
}

Document Version:

Peer reviewed version

Queen's University Belfast - Research Portal:

Link to publication record in Queen's University Belfast Research Portal

Publisher rights

(c) 2018 John Wiley \& Sons, Ltd. This work is made available online in accordance with the publisher's policies. Please refer to any applicable terms of use of the publisher.

\section{General rights}

Copyright for the publications made accessible via the Queen's University Belfast Research Portal is retained by the author(s) and / or other copyright owners and it is a condition of accessing these publications that users recognise and abide by the legal requirements associated with these rights.

Take down policy

The Research Portal is Queen's institutional repository that provides access to Queen's research output. Every effort has been made to ensure that content in the Research Portal does not infringe any person's rights, or applicable UK laws. If you discover content in the Research Portal that you believe breaches copyright or violates any law, please contact openaccess@qub.ac.uk. 


\title{
How Much Does Birth Weight Matter for Child Health in Developing Countries? Estimates from Siblings and Twins
}

\author{
Mark E. McGovern*1, 2 \\ ${ }^{1}$ CHaRMS - Centre for Health Research at the Management School, Queen's University Belfast \\ ${ }^{2}$ Centre of Excellence for Public Health (Northern Ireland)
}

September 2018

\begin{abstract}
200 million children globally are not meeting their growth potential, and as a result will suffer the consequences in terms of future outcomes. I examine the effects of birth weight on child health and growth using information from 66 countries. I account for missing data and measurement error using instrumental variables, and adopt an identification strategy based on siblings and twins. I find a consistent effect of birth weight on mortality risk, stunting, wasting, and coughing, with some evidence for fever, diarrhoea and anaemia. Bounds analysis indicates that coefficients may be substantially underestimated due to mortality selection. Improving the pre-natal environment is likely to be important for helping children reach their full potential.
\end{abstract}

JEL Classification: I12, O15, J13

Keywords: Birth Weight, Child Health, Mortality Selection

\footnotetext{
*Email: m.mcgovern@qub.ac.uk. I gratefully acknowledge support from the Program on the Global Demography of Aging, which is funded by the National Institute on Aging, grant no. P30 AG024409-11. I am also grateful to Marcella Alsan, Mary McEniry, Jocelyn Finlay, and seminar participants at Harvard University for helpful comments.
} 


\section{Introduction}

About 200 million children in developing countries are not reaching their potential, as defined by those who are adversely affected by growth restriction (Grantham-McGregor et al. 2007). In addition to the direct effect of child growth restriction on mortality itself (estimated at 2.2 million deaths in 2005), there are also substantial effects on morbidity; growth restriction was responsible for $21 \%$ of the overall global disease burden for children under 5 in 2008, as defined by Disability Adjusted Life Years (DALYs) lost (Black et al. 2008). The standard indicator used to measure growth restriction is stunting, typically defined as being below two standard deviations in terms of the WHO reference child's height for age (WHO 2011). Stunting represents the child's potential in the absence of nutritional constraints, in-utero growth restriction, and disease environment (Headey 2013). A third of all children in developing countries are affected by stunting, with prevalence highest in Africa, at 40\% (Black et al. 2008). The failure of children to reach their potential is likely to have a perpetuating effect on poverty, given that women of short stature are more likely to give birth to smaller babies (Victora et al. 2008). Unlike the relative success in tackling infant mortality (Hill et al. 2012; Rajaratnam et al. 2010), countries with a high prevalence of stunting have made less progress in addressing this issue (Bryce et al. 2008), and economic growth does not appear to greatly improve the situation for affected children (Vollmer et al. 2014). A closely related problem is anaemia, which refers to a reduced number of red blood cells or haemoglobin. Anaemia is often caused by iron deficiency and is associated with cognitive development and productivity. Globally, $50 \%$ of all children and $30 \%$ of all nonpregnant women are affected by this condition (Balarajan et al. 2011); moreover iron deficiency is increasing in some regions (Caulfield et al. 2006). The consequence of these conditions is that hundreds of millions of children are unable to take advantage of opportunities such as expansion in education, due to poor health (Walker et al. 2007).

As well as direct effects on health, labour supply is also likely to be affected by growth restriction (LópezCasasnovas et al. 2005). Specifically regarding the effects of stunting, there is credible evidence of large and significant effects on education (Glewwe and Miguel 2007). Glewwe et al. (2001) find that growth restriction affects education via both productivity and delayed enrollment by analysing a nutrition intervention programme in the Philippines, as do Alderman et al. (2001). The provision of nutritional supplements to families in Guatemala had a positive effect on grades completed for women who were affected as children, and on test scores for both men and women (Maluccio et al. 2009). A more long term follow-up of participants indicated that the intervention increased productivity in adults, which amounted to a $46 \%$ increase in 
average adult wages (Hoddinott et al. 2008). For recent summaries of the literature, see Dewey and Begum (2011) and Victora et al. (2008).

There is a body of research in economics on the causal impact of early life environment in higher income countries, including the effects of birth weight (Currie 2011). Therefore, we might expect these factors to be an important determinant of outcomes such as stunting and anaemia. For developing countries, recent studies have shown a strong correlation between measures of in utero environment and child health (Christian et al. 2013; Katz et al. 2013). However, we know comparatively little about the causal impact of these inputs in this context. Relatively worse early life conditions (compared to those previously studied in the literature) may imply even stronger long run effects in lower and middle income countries (Currie and Vogl 2013), where $27 \%$ (32 million) of total live births in 2010 were small for gestational age (Lee et al. 2013). ${ }^{1}$ Globally, babies of low birth weight $(<2,500 \mathrm{~g})$ account for $60-80 \%$ of neonatal mortality despite constituting only around a sixth of total births (Lawn et al. 2005).

There is also relatively little data on the optimal timing of intervention (Doyle et al. 2009). For example, it is important to know whether pregnant women should be targeted with nutritional supplements relatively more than targeting their children after birth. If it can be shown that there is no causal relationship between birth weight and child outcomes, then improving post-natal nutrition and disease environment are the relevant goals. However, if stunting can be causally attributed to birth weight, this implies that interventions which solely target child nutrition, and not maternal health and behaviour during pregnancy, will either not accomplish significant advances in helping children reach their full growth potential, or else will be an inefficient means of doing so. It may well be that there are no direct effects on certain outcomes, for example, Almond et al. (2005) find no impact of birth weight on mortality within twin pairs in the US. Early life health shocks may operate through pathways other than birth weight (Schulz 2010). The relevant question is then the magnitude of these effects relative to other pathways (particularly compared to the effects of malnutrition in childhood).

This paper adds to the literature by evaluating the effects of birth weight in a large sample of over a million children in 66 developing countries drawn from the nationally representative Demographic and Health Surveys (DHS). The few existing papers in this area tend to focus on specific countries or events. Bharadwaj et al. (2018) focus on educational outcomes in Chile. I also consider a set of health outcomes (such as stunting and anaemia), which are particularly relevant for this context. In addition, I make a number of

\footnotetext{
${ }^{1}$ Defined as being below the 10 th percentile for gestational age.
} 
methodological contributions. Specifically, I use data on siblings and twins to determine whether estimation of the relationship between birth weight and child health is affected by omitted variable bias. I account for measurement error and missing data using instrumental variables, an issue which is likely to be particularly important in estimates obtained from comparisons within families, as fixed effect models are known to exacerbate attenuation bias. Finally, using an approach previously adopted in the treatment effects literature, I consider the role of selection bias introduced by the absence of data on children who have died.

Overall, birth weight has a meaningful and consistent effect on child health. The observed relationships are non-linear, with the optimal weight typically lying above the usual low birth weight cut off of $2,500 \mathrm{~g}$. I find that these effects are likely to be underestimated by mortality selection, potentially substantially. Results therefore imply that a greater policy focus on improving infant health (of which birth weight is one potential marker) is warranted in less developed countries, as this is likely to raise the health capital and life chances of the affected children, in addition to potential productivity gains and intergenerational effects which arise as a consequence.

The rest of this paper is structured as follows. Section 2 reviews the existing literature which addresses the issue of causality, and motivates the focus on stunting and child health as important outcomes of interest to policy makers. Data are described in Section 3. Section 4 outlines the empirical strategy and Section 5 describes the results. Section 6 discusses mortality selection, while Section 7 concludes.

\section{What can we Learn from Twin Studies?}

A summary of the economics literature on the impact of initial environment is outlined in Almond and Currie (2011a) and Almond and Currie (2011b). A number of papers have used birth weight as a marker of early life conditions, and twin comparisons as a strategy to control for omitted variable bias (Almond et al. 2005; Behrman and Rosenzweig 2004; Black et al. 2007; Conley et al. 2003; Figlio et al. 2014; Oreopoulos et al. 2008; Royer 2009). In general, the literature finds lasting effects of early life conditions on health, education and earnings, although this is not always the case for twin studies. It is important to note that existing twin studies have almost exclusively relied on data from high income countries such as the US. Therefore, the analysis in this paper provides the opportunity to compare existing findings to estimates in a context where early life environments are potentially more adverse than those typically examined in the literature thus far. Some existing papers account for the endogeneity of early life health with birth weight differences in twin pairs. For example, Torche and Echevarria (2011) focus on the effects of birth weight on educational attain- 
ment in Chile using twin data, while Bharadwaj et al. (2018) examine how parental investments interact with initial endowments in the same data. Rosenzweig and Zhang (2009) address how birth weight and differential parental investment affects estimates of the effects of family size in China, and Rosenzweig and Zhang (2013) examine economic growth and gender differences, also using Chinese twins. Other papers have used natural experiments for identification. For example, Almond and Mazumder (2011) find that there are effects of being in utero during Ramadan, Linnemayr and Alderman (2011) exploit a series of early life interventions in Senegal, while Chen and Zhou (2007) and show that exposure to the Chinese famine resulted in stunting for those affected. Gørgens et al. (2012) demonstrate that selection effects are also present for Chinese famine survivors, while Blum et al. (2017) examine the same issue in the historical context of the Irish famine. Early life exposure to disease (Cutler et al. 2010; McEniry and Palloni 2010) and war (Blattman and Annan 2010) have also been shown to have important effects on later outcomes. For a full review, see (Currie and Vogl 2013) and (McEniry 2013). Although there are disadvantages associated with the twin approach, the benefit of the methodology used in this paper is that I am able to directly measure early life environment (with birth weight), and consider a set of health outcomes which are especially relevant for lower and middle income countries.

As outlined more formally in the following section, comparing the birth weight of twins (and to a lesser extent, siblings) provides a powerful means of accounting for unobserved factors which might otherwise bias estimates of the relationship between birth weight and later outcomes. For example, it is plausible that both are co-determined by some third factor which is difficult to measure, such as parental characteristics. However, there are potential drawbacks. Twins represent a relatively small fraction of total births (generally $1 \%$ ), and although it would ideally be possible to directly measure their foetal nutritional intake, this is unlikely to be feasible in practice. Recent research supports the hypothesis that differences in nutritional intake, specifically the structural arrangement of the foetuses, are a likely source of disparities in birth weight (Royer 2009). There is medical evidence which is consistent with this view, at least among children who share the same placenta (Bajoria et al. 2001). However, the validity of this approach depends on how birth weight discordances arise. For example, if within-twin discordance occurs due to differential caloric consumption, this is of interest to policy makers as this is a mechanism which is potentially susceptible to intervention, for example via programmes to improve maternal nutrition. However, as noted by Almond et al. (2005), if size disparities arise due to other factors such as blood supply, then the implications are less clear.

Under certain conditions, where birth weight was a function of say, chance placement in the womb, then 
within twin pair differences could be viewed as being as good as randomly assigned, approximating a natural experiment. Twins would then present the ideal opportunity to study the effects of birth weight. However, it is not clear whether these conditions are met. Factors which have been cited as determining the allocation of intra-uterine resources include implantation location of the placenta in the womb, nutritional sources at insertion point, and differential growth potential (for dizygotic twins). For identical twins who share the same placenta (monochorionic births, which occur in roughly $75 \%$ of monozygotic twins), the location of the insertion of the umbilical cord in the placenta is also likely to affect nutritional intake. It follows that there are two possible interpretations of estimates from twin studies. One is that within twin pair estimates of the effect of birth weight represent a causal parameter which is informative for policy intervention. The alternative is that there are numerous sources of birth weight differences, each of which has a differential effect on later outcomes (Almond et al. 2005). A conservative interpretation of the results in this paper is that birth weight represents a proxy for general in utero environment, in which case a comparison of full sample, sibling, and twin births is informative from the perspective of determining the extent to which estimates of the effects of early life conditions on later outcomes are affected by unobserved heterogeneity at both the family and child levels. Interpreting birth weight as more than a proxy for general in utero environment requires assumptions about the source of birth weight differences.

In addition to the possibility that different sources of variation in birth weight could have heterogeneous effects, there are a number of other concerns. Firstly, the extent to which it is possible to generalise from multiple births to singletons is not clear. For example, twins have higher rates of mortality, lower birth weight, shorter gestation, and shorter birth intervals. Nevertheless, recent research indicates that twins do not experience greater morbidity or mortality risk than singletons, conditional on survival past their first year (Öberg et al. 2012). There is also a loss of efficiency associated with both sibling and twin models, as siblings and twins represent a subset of the population of births, and information on singletons is ignored in family fixed effect models. This issue is exacerbated in the DHS because detailed information is only collected on births in the previous 5 years. Secondly, data on zygosity is rarely available. Therefore, it is difficult to rule out genetic differences as a potential explanation. For example, an individual child may be small, and yet not suffer any adverse long term effects due to having met their actual growth potential. In addition, even among identical twins, information on chorionicity (whether the placenta is shared) is difficult to obtain, and this may influence the magnitude of the effects of birth weight. A similar issue is the absence of data on gestational age in many surveys, which could potentially confound estimates of the impact of birth weight. Some cross-sectional studies have found that prematurity independently predicts child outcomes 
(Katz et al. 2013), while some twin studies have found that, conditional on birth weight, there is little effect of gestational age (Oreopoulos et al. 2008; Royer 2009). An attractive feature of twin studies is that they implicitly control for gestation without having to measure it directly because it is generally almost the same within twin pairs. This means that in sibling studies, the birth weight coefficient may incorporate the impact of gestational age, which we would expect to be positively correlated with birth weight and the outcome. If this is the case we would expect sibling estimates to be biased upwards when compared with twin estimates. However, even if gestational age is adjusted for in twin studies, this does not rule out the potential for the effects of birth weight to be more severe for premature births.

Finally, there may be differential investment behaviour by parents (Adhvaryu and Nyshadham 2014; Almond and Mazumder 2013; Oreopoulos et al. 2008; Royer 2009). For example, the less well-off twin (in terms of lower birth weight) may be provided with more health care. Alternatively, parents could conceivably direct more effort towards the better-off twin, depending on the cost of health inputs and the return to later health (Bharadwaj et al. 2018; Rosenzweig and Zhang 2009). Although these outcomes lie on the causal pathway, from a policy perspective it may be desirable to isolate the direct biological effect from the indirect effect due to differential parental investment, particularly if these effects are more amenable to intervention or heterogeneous by household type.

It is important to note that most of these concerns also apply to cross-sectional or sibling estimates of the effects of birth weight. However, twin models will provide results which are more biased (and inconsistent) than cross sectional estimates if endogenous variation accounts for a greater fraction of within twin differences in birth weight than of between family differences in birth weight (Bound and Solon 1999). Therefore, I return to address each of these issues in the empirical section of the paper.

\section{Data}

The Demographic and Health Surveys (DHS) are a series of cross sectional surveys that are generally nationally representative of women aged 15-49 in participating countries, of which there have been around 90 since 1984. As well as including a wide range of information on socio-demographic characteristics of families and households, detailed birth histories on all children born within the previous 5 years are generally collected. Anthropometric data (including height, weight, and, in some surveys, haemoglobin) are also taken from children who are alive at the time of interview. For a detailed description, see (Corsi et al. 2012). I include all surveys from rounds 2-6 which were available at the time of analysis, and which had information 
on household assets and birth weight. ${ }^{2}$ The analysis sample includes 161 country-years, 66 countries, and 1,151,556 children born between 1985 and 2011.

The main advantages of the data are the global and temporal coverage, the focus on developing countries, the sample size, the collection of anthropometric outcomes of specific policy importance, and the inclusion of siblings and twins. The disadvantages are the relatively short time frame for outcomes (up to 5 years of age), and the fact that birth weight is reported by the mother. Although previous research suggests that mother recall can be reliable (O'Sullivan et al. 2000; Tate et al. 2005; Walton et al. 2000), including in developing countries (Subramanyam et al. 2010), measurement error is likely to be an important problem, particularly if it is non-random. Figure A1 in the appendix demonstrates that there is evidence of heaping in the birth weight distribution. A related issue is that birth weight is missing for around $50 \%$ of children. Focusing on complete cases could provide a selected sample and biased results. For example, birth weight might only be consistently measured in medical facilities, and a substantial proportion of births occur at home (46\%). There is some evidence that ignoring missing data underestimates the extent of low birth weight (Moreno and Goldman 1990).

Descriptive statistics for other variables used in the analysis are presented in Table 1. Roughly $8 \%$ of children born in the five years prior to interview have died at the time of survey. There is a wide variety of data on the demographic characteristics of the mother and family, such as education, household assets, and a birth history calendar. More detailed information on recent pregnancies (within the past five years) is also collected, including ante-natal visits, whether the mother received a tetanus shot, and the mother's fertility goals. For children, there is further data on place of birth and anthropometrics. Height (or length, if the child is less than 2 years of age) and weight are measured by interviewers using digital scales and a measuring board. In some surveys, a capillary blood sample to measure haemoglobin content is taken using a finger or heel prick. Testing is then performed using a HemoCue photometer rapid test. Children were defined as anaemic if they had measured haemoglobin content of less than 10 grams per deciliter, adjusting for altitude. In addition to these objectively measured data, the mother is asked to report whether the child suffered from coughing, fever, or diarrhoea, the reference period for most surveys being the previous two weeks. Full details of the data collection procedure are available as part of the DHS manuals. ${ }^{3}$

For the base specification, I follow the existing literature, e.g. Finlay et al. (2011). However, despite the rich data available, there is the nevertheless still the potential for omitted variable bias. Therefore, it is important

\footnotetext{
${ }^{2}$ For an example of the questionnaire see: www.measuredhs.com/Publications/Publication-Search.cfm?type=35.

${ }^{3}$ measuredhs.com/pubs/pdf/DHSM7/DHS6_Biomarker_Manual_9Jan2012.pdf.
} 
to adopt an identification strategy to isolate the effect of interest. In addition to providing an identification strategy, another benefit of the method I outline is that when there are a large number of potential control variables, and many plausible interactions, matching siblings and twins is a powerful means of accounting for the bias that misspecification can induce. Finally, in some cases data on certain covariates is missing, and this approach is also useful for accounting for this.

\section{Empirical Strategy}

Consider a simple model for estimating the effects of birth weight on risk of death, where the mortality of child $i$ in family $j$ is a flexible function of birth weight (for example, a polynomial), a vector of control variables $X_{i j}$, a vector of family and parental characteristics $D_{j}$, with the subscript indicating that these characteristics do not vary within siblings or twin pairs, and an error term $u_{i j}$. We expect factors such as maternal and paternal ability, knowledge and pre-natal investments to be present in $D_{j}$. Because the characteristics (which include, for example, maternal age) present in $X_{i j}$ are considered common causes of pre-natal environment and post-natal outcomes, they are confounders which must be adjusted for (Bareinboim and Pearl 2016). The motivation for the specific factors to include in $X_{i j}$ is based on the previous DHS literature on child outcomes (Finlay et al. 2011). Similarly, characteristics such as maternal age which are not collinear with the fixed effects may affect reporting of size at birth (the instrument), and therefore must also be adjusted for in the IV analysis.

For simplicity I assume linearity of the other terms, however this assumption can be relaxed using matching on twins. This is the framework which is typically adopted in twin studies (Alderman et al. 2001; Ashenfelter and Krueger 1994; Behrman and Rosenzweig 2004; Behrman et al. 1994; Black et al. 2007 ; Conley et al. 2003; Figlio et al. 2014; Oreopoulos et al. 2008; Royer 2009).

As discussed above, there are two related issues which must be accounted for before the causal effects of in utero environment can be established. The first relates to missing data, as we only observe birth weight for a certain proportion of the sample. If measurement error is random, the addition of white noise will have the effect of biasing the estimated coefficient on birth weight towards zero (Hausman 2001). However, suppose instead that the presence of birth weight data also reflects some unmeasured attribute of the child or family which is related to both infant health and the outcome of interest, such as a component of neighbourhood or SES. For example, children without birth weight data may live in areas without access to health care 
Table 1 Descriptive Statistics

\begin{tabular}{|c|c|c|c|c|c|}
\hline & No. & $\%$ & & No. & $\%$ \\
\hline Place of Birth & & & Current Marital Status & & \\
\hline Own Home & 535,434 & 46.5 & Never Married & 30,722 & 2.7 \\
\hline Other Home & 55,407 & 4.8 & Married & 918,208 & 79.7 \\
\hline Government Hospital & 258,692 & 22.5 & Living Together & 138,945 & 12.1 \\
\hline Government Health Center & 168,594 & 14.6 & Widowed & 13,746 & 1.2 \\
\hline Private Hospital or Clinic & 115,959 & 10.1 & Divorced & 16,967 & 1.5 \\
\hline Other and Unknown & 9,982 & 0.9 & Not Living Together & 32,931 & 2.9 \\
\hline Missing & 7,488 & 0.7 & Total & $1,151,519$ & 100 \\
\hline \multirow[t]{2}{*}{ Total } & $1,151,556$ & 100 & & & \\
\hline & & & Religion & & \\
\hline Birth Interval & & & Christian & 416,227 & 43.2 \\
\hline First Birth & 285,408 & 24.8 & Muslim & 321,472 & 33.4 \\
\hline 1-11 months & 10,335 & 0.9 & Jewish & 2,481 & 0.3 \\
\hline $12-17$ & 65,926 & 5.7 & Buddhist & 26,149 & 2.7 \\
\hline $18-23$ & 116,642 & 10.1 & Hindu & 123,885 & 12.9 \\
\hline $24+$ & 673,245 & 58.5 & Sikh & 3,323 & 0.3 \\
\hline \multirow[t]{2}{*}{ Total } & $1,151,556$ & 100 & Traditional & 18,420 & 1.9 \\
\hline & & & Other & 21,023 & 2.2 \\
\hline Mother's Age & & & None & 28,542 & 3.0 \\
\hline $15-19$ & 71,611 & 6.2 & Unknown & 1,234 & 0.1 \\
\hline $20-24$ & 291,874 & 25.3 & Total & 962,756 & 100 \\
\hline $25-29$ & 326,686 & 28.4 & & & \\
\hline $30-34$ & 227,915 & 19.8 & Multiple Birth & & \\
\hline $35-39$ & 146,177 & 12.7 & Single Birth & $1,120,925$ & 97.3 \\
\hline $40-44$ & 66,573 & 5.8 & 1st of Multiple & 15,189 & 1.3 \\
\hline $45-49$ & 20,691 & 1.8 & 2nd of Multiple & 15,234 & 1.3 \\
\hline \multirow[t]{2}{*}{ Total } & $1,151,527$ & 100 & 3rd of Multiple & 201 & $<0.1$ \\
\hline & & & 4 th of Multiple & 7 & $<0.1$ \\
\hline Mother's Education & & & Total & $1,151,556$ & 100 \\
\hline No Education & 432,185 & 37.5 & & & \\
\hline Primary & 392,742 & 34.1 & Partner's Education & & \\
\hline Secondary & 270,511 & 23.5 & No Education & 312,748 & 27.2 \\
\hline Higher Education & 55,859 & 4.9 & Primary & 364,076 & 31.6 \\
\hline Don’t Know/Missing & 259 & $<0.1$ & Secondary & 327,543 & 28.4 \\
\hline \multirow[t]{2}{*}{ Total } & $1,151,556$ & 100 & Higher Education & 85,562 & 7.4 \\
\hline & & & Don’t Know/Missing & 61,627 & 5.4 \\
\hline Size of Child at Birth & & & Total & $1,151,556$ & 100 \\
\hline Very Large & 80,131 & 7.0 & & & \\
\hline Larger than Average & 248,706 & 21.6 & Region & & \\
\hline Average & 583,861 & 50.7 & India & 154,576 & 13.4 \\
\hline Smaller than Average & 159,558 & 13.9 & North Africa/Europe & 110,577 & 9.6 \\
\hline Very Small & 61,898 & 5.4 & South East Ásia & 152,055 & 13.2 \\
\hline Don't Know & 17,402 & 1.5 & Latin America & 157,491 & 13.7 \\
\hline \multirow[t]{2}{*}{ Total } & $1,151,556$ & 100 & Sub-Saharan Africa & 576,857 & 50.1 \\
\hline & & & Total & $1,151,556$ & 100 \\
\hline \multicolumn{6}{|l|}{ Wealth Index } \\
\hline Poorest & 281,323 & 24.4 & Wanted a Pregnancy & & \\
\hline Poorer & 242,378 & 21.0 & Then & 815,894 & 70.9 \\
\hline Middle & 227,922 & 19.8 & Later & 190,605 & 16.6 \\
\hline Richer & 211,130 & 18.3 & No More & 140,000 & 12.2 \\
\hline Richest & 188,803 & 16.4 & Don’t Know/Missing & 5,057 & 0.4 \\
\hline Total & $1,151,556$ & 100 & Total & $1,151,556$ & 100 \\
\hline
\end{tabular}




\begin{tabular}{lcccc}
\hline & Median & Mean & SD & $\mathrm{N}$ \\
\hline Survey Year & 2003 & 2001.93 & 5.83 & $1,151,556$ \\
Year of Birth & 2000 & 1999.58 & 5.93 & $1,151,556$ \\
Male & 1 & 0.51 & 0.50 & $1,151,556$ \\
Months Since Birth & 27 & 27.72 & 16.97 & $1,151,556$ \\
Child is Dead & 0 & 0.08 & 0.26 & $1,151,556$ \\
Birth Weight & 3100 & 3165.35 & 669.04 & 527,050 \\
Birth Weight (With Imputations) & 3000 & 3122.46 & 773.76 & $1,151,513$ \\
Birth Order (Birth History) & 1 & 1.33 & 0.56 & $1,151,556$ \\
Has Flush Toilet & 0 & 0.23 & 0.42 & $1,103,336$ \\
Has Piped Water in House & 0 & 0.38 & 0.48 & $1,116,302$ \\
Urban & 0 & 0.33 & 0.47 & $1,151,556$ \\
Mother Had Tetanus Shot & 1 & 0.70 & 0.46 & 904,880 \\
Mother Had Ante-Natal Visit & 1 & 0.79 & 0.41 & 912,190 \\
Height for Age Z Score & -1.55 & -1.49 & 1.78 & 746,694 \\
Height for Weight Z Score & -0.1 & -0.14 & 1.49 & 736,822 \\
Stunting & 0 & 0.39 & 0.49 & 746,694 \\
Wasting & 0 & 0.10 & 0.30 & 736,822 \\
Fever & 0 & 0.27 & 0.44 & $1,025,331$ \\
Cough & 0 & 0.29 & 0.45 & $1,034,954$ \\
Diarrhoea & 0 & 0.16 & 0.37 & $1,046,605$ \\
Anaemia & 1 & 0.60 & 0.49 & 221,489 \\
Haemoglobin & 106 & 104.44 & 20.35 & 214,162 \\
\hline
\end{tabular}

Source: Demographic and Household Surveys Waves 2-6

facilities. Imputation could potentially induce additional mis-measurement which could be systematically correlated with unobservables. The measurement error problem can be represented as the observed birth weight (either present in the data or imputed because of missingness) being some function of true birth weight $\left(B W_{i j}^{*}\right)$ and some aspect of family environment $\left(z_{j}\right) . z_{j}$ could potentially be a subset of $D_{j}$ or include additional variables.

In addition to the data which are missing, even if birth weight is observed in the data, it is possible that measurement error is systematically associated with some background characteristic of the mother. Suppose women with less education tend to under-estimate the birth weight of their children, and that mother's education also impacts positively on their children's weight and height. Results obtained under the assumption of missing at random would then be biased upwards in a similar manner to if there was omitted variable bias, due to correlation between the measure of birth weight and the error term, $u_{i j}$. Suppose instead that this reporting bias is a function of some indicator of parental characteristics which is not observed in the data. This model is shown in Equation 1:

$$
\text { Mortality }_{i j}=X_{i j}^{\prime} \gamma+\sum_{k=1}^{K} \beta_{k}\left(B W_{i j}^{*}+z_{j}\right)^{k}+D_{j}^{\prime} \theta+u_{i j}
$$

Where the superscript $k$ indexes the degree of the polynomial under consideration. The estimates of the 
effects of birth weight on mortality ( $\beta_{k}$, the parameter(s) of interest) will be biased even when birth weight is instrumented, except when the instrument is uncorrelated with the family fixed effect. An obvious solution to this problem is to use a sibling comparison model, given that we have data on multiple children per family. However, a fixed effects model will typically exacerbate the measurement error problem unless it is highly correlated within groups (either siblings or twins). In the case of classical measurement error and a linear specification, it can be shown, e.g. Deaton (1997); Griliches (1979); Kohler et al. (2011); that:

$$
\operatorname{plim}\left(\beta_{B W}^{F E}\right)=\beta\left(\frac{1-\sigma_{e_{i j}}^{2}}{\sigma_{B W_{i j}^{*}}^{2}\left(1-\rho_{B W}\right)}\right)
$$

Where $\rho_{B W}$ is the within group correlation in birth weight. If the within group measurement error is correlated, as implied by the inclusion of $z_{j}$ in Equation 1 above, then:

$$
\left.\operatorname{plim}\left(\beta_{B W}^{F E}\right)=\beta\left(1-\left[\left(1-\rho_{z}\right)\left(1-\rho_{B W}\right) \cdot \sigma_{e_{i j}}^{2} \cdot \sigma_{B W_{i j}^{*}}^{2}\right)\right]\right)
$$

So that $\operatorname{plim}\left(\beta_{B W}^{F E}\right)=\beta$ only where $\rho_{z}=1$ (the within twin pair measurement error is perfectly correlated), and in general the fixed effects estimate in Equation 1 will be more inconsistent than an OLS model as long as $\rho_{z}<\rho_{B W}$. For example, in the context of estimating the effects of education, plausible amounts of noise results in attenuation bias of $8 \%$ for OLS estimates, $16 \%$ for dizygotic twin models, and $32 \%$ for monozygotic twin models (Kohler et al. 2011).

However, when an alternative measure of the variable of interest is available, it is still possible to obtain consistent estimates when there is correlated measurement error by instrumenting for differences in the explanatory variable of interest with differences in the secondary measure. This approach has been previously applied to the case of estimating the returns to schooling in twins where twin reports of the other's education are used as an instrument for their own (Ashenfelter and Krueger 1994; Behrman et al. 1994). Applying the usual fixed effects transformation to the model above (where the family means are subtracted from the individual level variables), and instrumenting for birth weight, we obtain:

$$
\widetilde{M o r t a l i t y}_{i j}=\widetilde{X_{i j}^{\prime}} \gamma+\sum_{k=1}^{K} \beta_{k}\left(\widehat{B W}_{i j}\right)^{k}+e_{i j}
$$

Where $\sim$ donates the within family transformation such that $\widetilde{x_{i j}}=x_{i j}-1 T_{j} \sum_{t=1}^{T_{j}} x_{i j t}$ for all $T_{j}$ members of 
family $j$. The advantage of using twin data is that it accounts for unmeasured initial parental investment or other endowments, as each of $z_{j}-\widetilde{z_{j}}$ and $D_{j}-\widetilde{D_{j}}$ can more reasonably be assumed to be zero. $\widehat{B W}_{i j}$ is the predicted value from the equation:

$$
\widehat{B W}_{i j}=\widetilde{X_{i j}^{\prime}} \delta+\sum_{s=1}^{4} \phi_{s} \text { Size at } \widetilde{B_{i r t h}}{ }_{s i j}+\kappa_{i j}
$$

Where differences in birth weight are instrumented with differences in the reported Size at Birth $_{s i j}$ $s=1,2,3,4$, ranging from "very small" to "large". The two measures (birth weight and size) are highly correlated, as confirmed by first stage partial $F$ statistics and as illustrated in Figure A2 in the appendix. The approach of augmenting the DHS birth weight data with auxiliary information on size has been previously recommended (Blanc and Wardlaw 2005; Moreno and Goldman 1990), although not yet implemented in the framework of instrumental variables. This method does require an exclusion restriction for consistency, which is that the measurement error in birth weight and size at birth is uncorrelated (conditional on mother or twin pair fixed effects). As it seems plausible that there would be systematic reporting differences across siblings, even conditional on having the same mother (for example, due to recall), this highlights another advantage of using data on twins, where the coefficient(s) of interest is then identified from differences in relative size within twin pairs.

In summary, the estimation procedure is as follows. I first impute the missing values using predictive mean matching, which has the advantage of returning a distribution which matches the observed bounds on birth weight (Little 1988). The imputation model includes all covariates to be used in the regression model for the effects of birth weight, with the addition of the outcomes of interest and size at birth. Two models are run, one for mortality, and one for the other health outcomes combined. In addition, missing values are imputed separately by country. Although this approach is likely to induce measurement error, under the exclusion restriction the instrumental variables strategy should account for this problem. The existence of attenuation bias is indeed supported by the empirical results, however the resulting estimates for the effects of birth weight in the preferred IV fixed effects model do not appear to be sensitive to the implementation of the imputation model.

Although 2,500g is the typical cut-off for low birth weight, previous research has found that the presence of a discontinuity at this value is not necessarily supported by the data, in that the optimal birth weight 
is likely to be substantially higher (Royer 2009). ${ }^{4}$ Therefore, I begin by investigating the functional form for the effects of birth weight on the childhood outcomes using a restricted cubic spline approach. This model takes the form of a function with continuous first and second derivatives, specifically a cubic function between adjacent knots $K N_{1}<K N_{2}<\ldots<K N_{K}$, and a linear function for $K N_{K}<B W_{i j}<K N_{1}$ (Korn and Graubard 1999). For 3 knots and one independent variable, this can be defined as follows:

$$
\text { Mortality }_{i j}=\left(B W_{i j}-K N_{1}\right)_{+}^{3}-\frac{K N_{3}-K N_{1}}{K N_{3}-K N_{2}}\left(B W_{i j}-K N_{2}\right)_{+}^{3}+\frac{K N_{2}-K N_{1}}{K N_{3}-K N_{2}}\left(B W_{i j}-K N_{3}\right)_{+}^{3}
$$

Where $\left(B W_{i j}\right)_{+}=B W_{i j}$ if $B W_{i j}>0$, and 0 otherwise. The results of this preliminary analysis are shown in Figure $1 .^{5}$ In all cases, non-linearity is apparent, with optimal weight lying above the standard 2,500g low birth weight threshold. This is in line with the findings in Alderman et al. (2001) and Royer (2009), who also implement a similar analysis using linear spline functions. Figure A3 in the appendix illustrates the corresponding analysis for twins. Particularly for the twin sample, the addition of control variables increases the associated confidence intervals for heavier babies, but does not substantially alter the conclusions. Another pattern is apparent; increases in birth weight above 4,000g are generally associated with worsening outcomes (with the exception of stunting and anaemia). In the above I have assumed that the measurement error structure is not associated with true underlying birth weight (for example if reported birth weight was systematically greater, in a way not captured by the model specification, for those with higher real birth weight). It is difficult to assess the implications of this for the following analysis without imposing priors on both the structure of the measurement error and the potentially non-linear effect of birth weight itself (since the interaction of both will determine the extent of the bias). To the extent that splines can produce more accurate local estimates of treatment effects at parts of the distribution which are less affected by measurement error, adopting a flexible functional form may be beneficial. However, depending on the structure of the measurement error and the birth weight effect this may not necessarily be the case. Assuming the conditions required for the IV analysis hold and this approach successfully adjusts for any misreporting, a comparison between models with and without measurement error correction may indicate the extent to which non-linearities are likely to be present, although we must assume the absence of other types of unobserved confounding for this to be valid. Comparison of reported birth weight with registry data did not suggest greater measurement error at the extremes of the distribution (Tate et al. 2005), and

\footnotetext{
${ }^{4}$ Here 'optimal' birth weight can be thought of in terms of the birth weight which maximises child health outcomes, inclusive of any post-natal medical interventions or parental investments.

${ }^{5}$ This graph shows the analysis for 3 knots, using additional knots gives similar results.
} 
in regressions comparing the predictive power of reported birth weight and recorded birth weight in India for child outcomes (Subramanyam et al. 2010), the recall and card data gave almost identical results, which supports the hypothesis that the measurement error may not be systematically affecting estimates.

An alternative to the spline model is a log linear specification, however this imposes diminishing returns (i.e. monotonicity), and precludes adverse effects at high birth weights. This affects relatively few babies, as $4,000 \mathrm{~g}$ lies at the $90 \%$ percentile, but nevertheless, this spline analysis indicates that the effects are roughly quadratic. In Section 6 I show that using a single indicator for low birth weight also suggests substantial effects.

Although in theory semi-parametric and non-parametric IV models could be adopted to adjust for measurement error, in practice the number of endogenous parameters $\left(\beta_{k}\right)$ is limited to the number of suitable instruments. Given the functional form analysis in Figure 2, I therefore adopt a more parsimonious approach specifying a second order polynomial for birth weight. Diagnostic tests confirm that this model is identified using the four categories of size at birth as instruments, as shown by the Anderson LM (Anderson 1951) tests in Table A12 in the appendix. Therefore, the final model is given by:

$$
\text { Mortality } i j=\widetilde{X_{i j}^{\prime}} \gamma+\beta_{1}{\widehat{B W_{i j}}}+\beta_{2} B \widehat{W}_{i j}^{2}+\epsilon_{i j}
$$

I report the marginal effect of birth weight at 2,500g for comparability with previous literature, however improvements across the wider distribution are also likely to be of interest to policy makers based on the spline analysis.

$$
\frac{d M o r t a l i t y}{d B W}=\beta_{1}+2 \beta_{2} B W
$$

In the following section, I begin by presenting OLS results for the effects of birth weight where I control for the variables outlined in Table 1 using the model in Equation 5. Table A3 in the appendix presents a summary of the main outcomes for each of the samples (all births, births with birth weight data, siblings and twins). The most apparent feature of the data is that, as expected, twins are more disadvantaged on all measures. For example, mean birth weight is around 2,600g for multiple births compared to around $3,100 \mathrm{~g}$ in the other samples. Mortality is $26 \%$, compared to $8 \%$ in the full sample. Stunting is over $50 \%$, compared to around $40 \%$ for the full sample and siblings. 
I use OLS for all outcomes as this is generally the approach adopted when considering binary outcomes in the economics literature (Angrist and Pischke 2008). This allows direct estimation of the marginal effect, and avoids computational difficulties associated with implementing logit or probit models, which in this case are problematic because the full sample comprises over a million observations with a relatively large set of covariates (before considering the imputations). The linear probability model is often adopted in analysis of twin data in the economics data, including the mortality outcomes considered in Almond et al. (2005). In addition, the linear probability model more readily accommodates combined fixed effect and instrumental variables analysis.

I determine whether sample composition is likely to affect external validity of results by comparing results in different groups. I show estimates from models using complete data on birth weight for the OLS and IV models. For each of these cases, results are compared for all children, siblings and twins, with and without imputed values for missing birth weight data. Because there are trade-offs involved in using each of the different approaches (twin models can account for additional unobserved confounders over and above sibling comparisons, for instance gestational age, however the latter are less of a selected sample and potentially more efficient because they use more of the available data), I view cases where results are similar across models as being most informative. If the effect of birth weight is found to be robust across these specifications, this would provide reasonable evidence that the effect was likely to be consistent in different populations.

An important question when estimating fixed effects models is the extent of variation in the variables of interest. Figure 2 indicates that there appears to be satisfactory variation in birth weight. The distribution is similar to that reported in Black et al. (2007) for Norway. ${ }^{6}$ For example, their mean twin difference is $320 \mathrm{~g}$, compared to a mean difference of $318 \mathrm{~g}$ in the DHS sample. The standard deviation for DHS twins is also comparable to the full DHS sample. Discordance probabilities for size at birth and the main outcomes of interest (mortality, stunting, fever, coughing, diarrhoea, and anaemia) are shown in Table A2 in the appendix. For the former, the probability of twin 2 being the same size as twin 1 ranges from $64 \%$ to $79 \%$ depending on the category. Ranges are similar for mortality, stunting and anaemia, but discordance probabilities are lower for fever, coughing and diarrhoea.

\footnotetext{
${ }^{6}$ See Figure 2 on page 420 of Black et al. (2007).
} 
Figure 1 Restricted Cubic Spline Models for Birth Weight
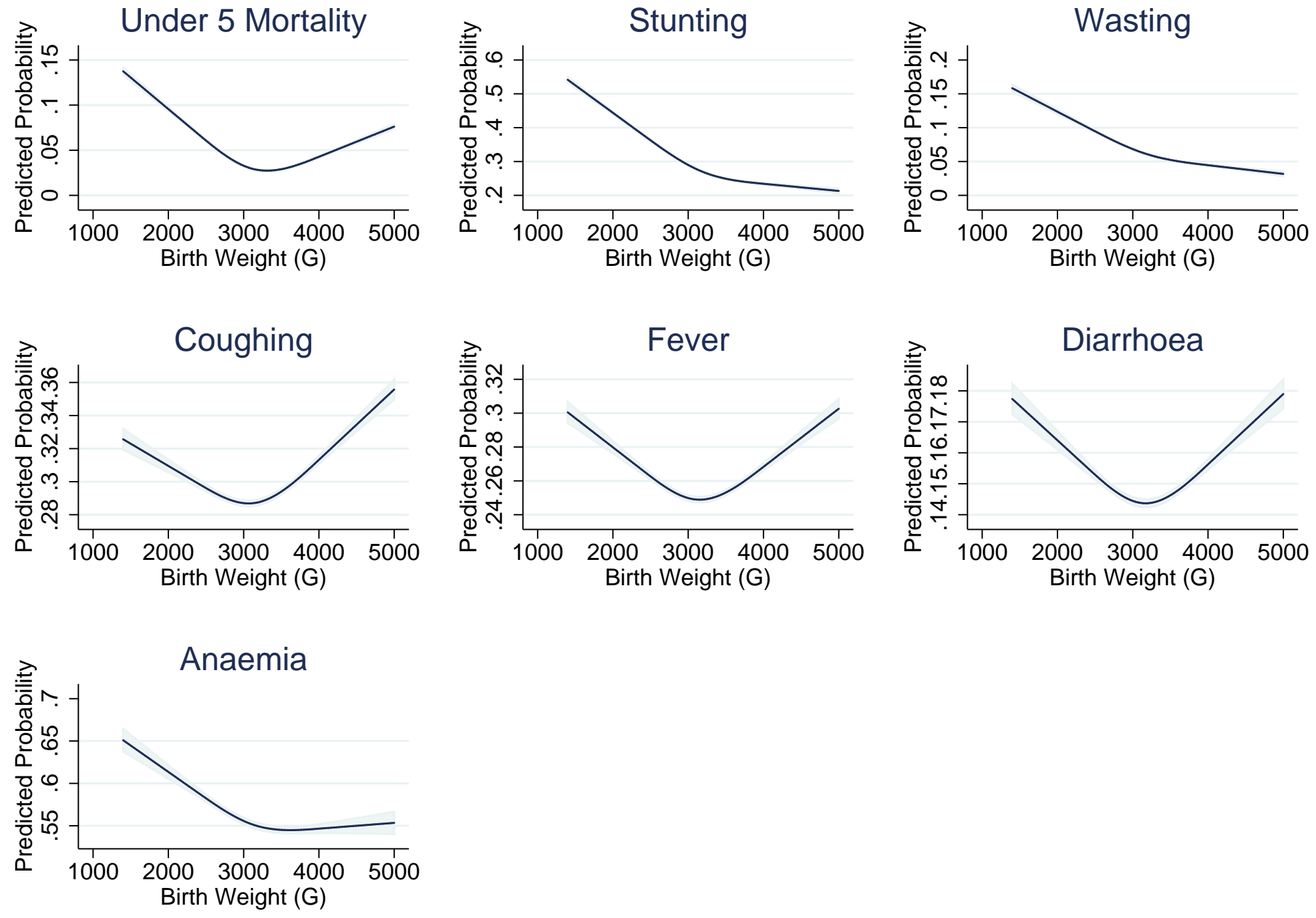

Note: Graph shows the predicted probability of each outcome by birth weight using a restricted cubic spline model with 3 knots. $95 \%$ confidence intervals are shown, and adjusted for clustering at the household level. The sample uses all children with complete birth weight data. 
Figure 2 Twin Differences in Birth Weight
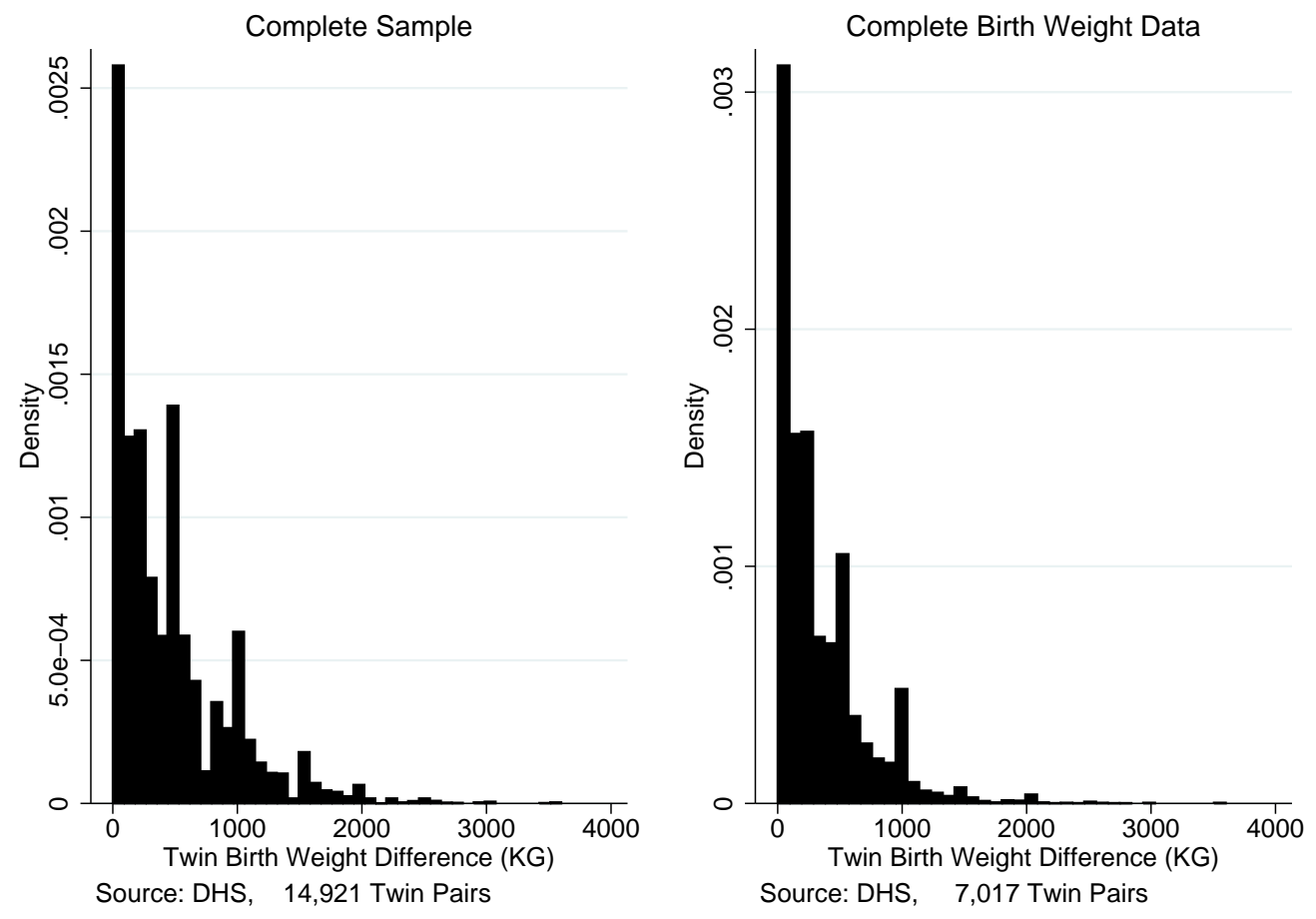

\section{Results}

\section{$5.1 \quad$ Mortality}

Table 2 presents results for under 5 mortality. The outcome is a binary variable indicating whether the child is alive at the time of interview. Children in the sample are up to 59 months of age. Birth weight is entered as a quadratic, and the coefficient reported is the marginal effect at 2,500g. Two panels are presented, the first includes the full sample of children, while the second is restricted to twins. The first two columns use observations with reported birth weight. For the first panel, this amounts to data on roughly 650,000 children. The third and fourth columns are based on the model where imputed birth weight (and birth weight squared) is used for missing observations. For all outcomes I use 5 imputations to account for uncertainty in the prediction of missing values, and the following tables report these results, however I have also verified that estimates are not sensitive to increasing the number of imputations. 
Table 2 200g Marginal Effect of Birth Weight on Under 5 Mortality (at 2,500g)

\begin{tabular}{|c|c|c|c|c|}
\hline Variables & OLS Full Sample & Mother IV FE & OLS Full Sample & Mother IV FE \\
\hline & \multicolumn{4}{|c|}{ All Children } \\
\hline Birth Weight & $\begin{array}{c}-0.010^{* * *} \\
(0.000)\end{array}$ & $\begin{array}{c}-0.017^{* * *} \\
(0.001)\end{array}$ & $\begin{array}{c}-0.006^{* * *} \\
(0.000)\end{array}$ & $\begin{array}{c}-0.017^{* * *} \\
(0.001)\end{array}$ \\
\hline Imputations & No & No & Yes & Yes \\
\hline \multirow[t]{2}{*}{ Observations } & 527,027 & 263,214 & $1,151,490$ & 644,047 \\
\hline & \multicolumn{4}{|c|}{ Twins } \\
\hline Birth Weight & $\begin{array}{c}-0.017^{* * *} \\
(0.001)\end{array}$ & $\begin{array}{c}-0.008^{* *} \\
(0.004)\end{array}$ & $\begin{array}{c}-0.011^{* * *} \\
(0.001)\end{array}$ & $\begin{array}{c}-0.008^{* * *} \\
(0.003)\end{array}$ \\
\hline Imputations & No & No & Yes & Yes \\
\hline Observations & 14,364 & 13,960 & 29,840 & 29,008 \\
\hline
\end{tabular}

Note: The model shows the marginal effect of a $200 \mathrm{~g}$ increase on the outcome at $2,500 \mathrm{~g}$ estimated using a quadratic specification for birth weight. Columns 1 and 3 include controls for month of birth, year of birth fixed effects, gender, birth order, order in birth history calendar, place of birth, birth interval, multiple birth, mothers age, urban/rural location, partner's education, toilet in house, water in house, marital status, survey year fixed effects, religion, maternal tetanus injection, fertility preference, ante-natal visits by the mother, country specific year of birth trends, country specific wealth index quintile, and country fixed effects. Columns 2 and 4 implement the mother fixed effects model, with controls for gender, months since birth, year of birth fixed effects, multiple birth, month of birth, place of birth, birth interval, birth history, maternal tetanus, antenatal visits, and wanted birth. The second panel uses the same specification, except restricting the sample to twins. The twin fixed effect models include controls for gender and birth order. The full table for columns 1 and 2 are presented in the appendix, as are tables showing first stage estimates. Standard errors are adjusted for clustering at the household level, as well as for 5 replications in the model which imputes missing data on birth weight and birth weight squared (Rubin 2009). 
Columns 1 and 3 are the basic linear probability model. The instrumental variables fixed effects model is implemented in columns 2 and 4, where the coefficients are generated by sibling comparisons in the first panel, and twin comparisons in the second. ${ }^{7}$ Birth weight and birth weight squared are instrumented with reported size at birth. First stage results are presented in the appendix in Table A12. Tables A13 to A16 in the appendix also show the complete tables with coefficients on the other covariates.

As birth weight is measured in grams in the data, resulting estimates are multiplied by 200 so that the coefficients in Table 2 indicate the effect of a 200g increase (at 2,500g). In the first column and panel, a 200g increase in birth weight is found to decrease the probability of mortality by 1 percentage point. However, it is more correct to think of the coefficient in terms of a $1 \mathrm{~g}$ increase in birth weight, seeing as the derivative for the marginal effect, $\frac{d y}{d x}=\left.\frac{d \text { Mortality }}{d B W}\right|_{B W=2,500 g}$ in Equation 6 , is theoretically only valid for a small change in $x$ (so for example, a coefficient of -0.01 in Table 2 more correctly indicates that a $1 \mathrm{~g}$ increase in birth weight reduces the probability of mortality by $\frac{1}{200}=.005$ percentage points). However, I present results for 200g as Royer (2009) gives this figure as being a plausible target for government intervention, and Almond et al. (2005) indicate that 200g is the improvement in birth weight for affected infants that could reasonably be expected from ending maternal smoking. $200 \mathrm{~g}$ is also close to the estimated effect of participation in the Special Supplemental Nutrition Program for Women, Infants, and Children (WIC) in the US (Kowaleski-Jones and Duncan 2002).

Given that overall mortality is $8 \%$ in the sample, the effect size in Table 2 appears to be substantial. There is a consistent and positive effect of birth weight on child mortality in all specifications, ranging from a .6 percentage point decrease in the risk of mortality per $200 \mathrm{~g}$ increase, to a 1.7 percentage point decrease. The preferred twin IV fixed effects model on the full sample indicates an effect size of .8 percentage points.

In order to evaluate the implementation of the IV model, I conduct a number of additional analyses. First, it is important to note that the first stage partial $F$ statistics and corresponding Anderson LM (Anderson 1951) tests indicate that the excluded instruments are relevant and that the model is identified. Second, given that there are four instruments (four categories of size at birth), and two endogenous regressors (birth weight and birth weight squared), it is feasible to conduct a test of overidentifying restrictions. For the preferred twin specification, we fail to reject the null that the instruments are valid. ${ }^{8}$ However, given the alternative instruments are different categories of the same underlying variable, this is best thought of as a specification test rather than a test of instrument exogeneity. Third, the reduced form relationship between

\footnotetext{
${ }^{7}$ There are a small number of triplets and quadruplets which are not included.

${ }^{8}$ Table A12 in the appendix.
} 
size at birth and mortality indicates a strong and negative association, including in the twin fixed effect models. ${ }^{9}$ Finally, when I restrict the sample to countries with relatively lower rates of missingness for birth weight $(<50 \%)$, I get very similar results. ${ }^{10}$

\subsection{Child Health Outcomes}

Table 3 200g Marginal Effect of Birth Weight on Stunting (at 2,500g)

\begin{tabular}{|c|c|c|c|c|}
\hline Variables & OLS Full Sample & Mother IV FE & OLS Full Sample & Mother IV FE \\
\hline & \multicolumn{4}{|c|}{ All Children } \\
\hline Birth Weight & $\begin{array}{c}-0.024^{* * *} \\
(0.000)\end{array}$ & $\begin{array}{c}-0.028^{* * *} \\
(0.002)\end{array}$ & $\begin{array}{c}-0.009^{* * *} \\
(0.000)\end{array}$ & $\begin{array}{c}-0.023^{* * *} \\
(0.001)\end{array}$ \\
\hline Imputations & No & No & Yes & Yes \\
\hline \multirow[t]{2}{*}{ Observations } & 338,540 & 160,804 & 746,662 & 388,988 \\
\hline & \multicolumn{4}{|c|}{ Twins } \\
\hline Birth Weight & $\begin{array}{c}-0.023^{* * *} \\
(0.002)\end{array}$ & $\begin{array}{c}-0.020^{* * *} \\
(0.006)\end{array}$ & $\begin{array}{c}-0.010^{* * *} \\
(0.001)\end{array}$ & $\begin{array}{c}-0.023^{* * *} \\
(0.005)\end{array}$ \\
\hline Imputations & No & No & Yes & Yes \\
\hline Observations & 7,448 & 7,398 & 13,504 & 13,326 \\
\hline
\end{tabular}

Table 3 presents a similar analysis for the effects of birth weight on stunting (more than 2 standard deviations below the WHO reference in terms of height for age). As with mortality, the outcome is a binary variable and I use a linear probability model. And as with mortality, the effect of birth weight is consistently negative. The cross sectional estimates for the full sample and twins are comparable. Overall, estimates in the preferred twin IV models indicate a reduction in the probability of stunting of between 2 and 2.3 percentage points per $200 \mathrm{~g}$ increase in birth weight at $2,500 \mathrm{~g}$, depending on whether imputations are included or not. Table

\footnotetext{
${ }^{9}$ Table A3 in the appendix.

${ }^{10}$ Table A4 in the appendix.
} 
A5 in the appendix illustrates that effects are similar for wasting, with the corresponding results implying a 1.1 to 1.2 percentage point reduction per 200g. ${ }^{11}$ Tables A7-A6 in the appendix present results for coughing, fever, diarrhoea and anaemia.

\subsection{Heterogeneity}

While the cubic spline approach is flexible, it is still an imposition of functional form on an unknown true birth weight effect, and therefore it is important to consider whether the results are robust to this assumption. This is particularly the case if there are concerns about measurement error affecting a certain part of the distribution (for example, babies of high birth weight). Table 4 presents results for the twin sample using an indicator for low birth weight, and results remain statistically significant and large in magnitude. For example, being low birth weight is associated with a 6 percentage point increase in the risk of mortality. From a policy perspective, it is difficult to assess whether this coefficient or the one presented in Table 2 is most relevant without imposing a prior on the functional form of the birth weight effect. However, in each of the analyses the magnitude of the birth weight impact appears large enough to be meaningful in terms of its effect on later outcomes.

In order to address some of the potential limitations of twin studies raised in Section 2, I also consider a series of robustness checks for gender, birth order, family wealth category, and birth weight differences in Tables A9-A10, and find little clear evidence of heterogeneous effects. Although, the reduced sample size in stratified models means it is difficult to be conclusive without additional data. I have also estimated models which include an age interaction with birth weight. Infants may be more vulnerable to low birth weight, it may be possible to compensate for early disadvantage, and catch-up growth may be possible. Figure 3 implements a model for age-specific mortality. The first model is for neonatal infant mortality (within one month since birth), and the second is for infant mortality (within the first year). The fourth is for deaths under 5 years of age (replicating the results in table 1). The third column is for infant mortality excluding neonatal deaths (i.e. deaths between 1 month and 1 year), and the fifth column is for mortality between 1 year and 5 years of age. The marginal effect is largest for the neonatal period, which accounts for roughly a third of all deaths under 5. This finding has particular relevance for the relatively lesser progress in reducing neonatal mortality (Lawn et al. 2006) compared to the infant death rate. These results suggest that improvements in infant health may be a means of achieving the sustainable development goal target of reducing child mortality. For stunting, birth weight effects decline with age but remain statistically significant even at 59 months.

\footnotetext{
${ }^{11}$ Compared to stunting, height for weight (wasting) captures more immediate nutritional deprivation (Headey 2013).
} 
Table 4 Results for Low Birth Weight (Twin Sample)

\begin{tabular}{ccc} 
& Mortality & Stunting \\
\hline Low Birth Weight $(<2500 \mathrm{~g})$ & $0.06^{* * *}$ & $0.11^{* * *}$ \\
& $(0.01)$ & $(0.01)$ \\
\hline
\end{tabular}

Clustered standard errors in parentheses

*** $\mathrm{p}<0.01,{ }^{* *} \mathrm{p}<0.05,{ }^{*} \mathrm{p}<0.1$

Control variables are included, see note to Table 2 .

Figure 3 Effects of Birth Weight on Mortality by Age at Death

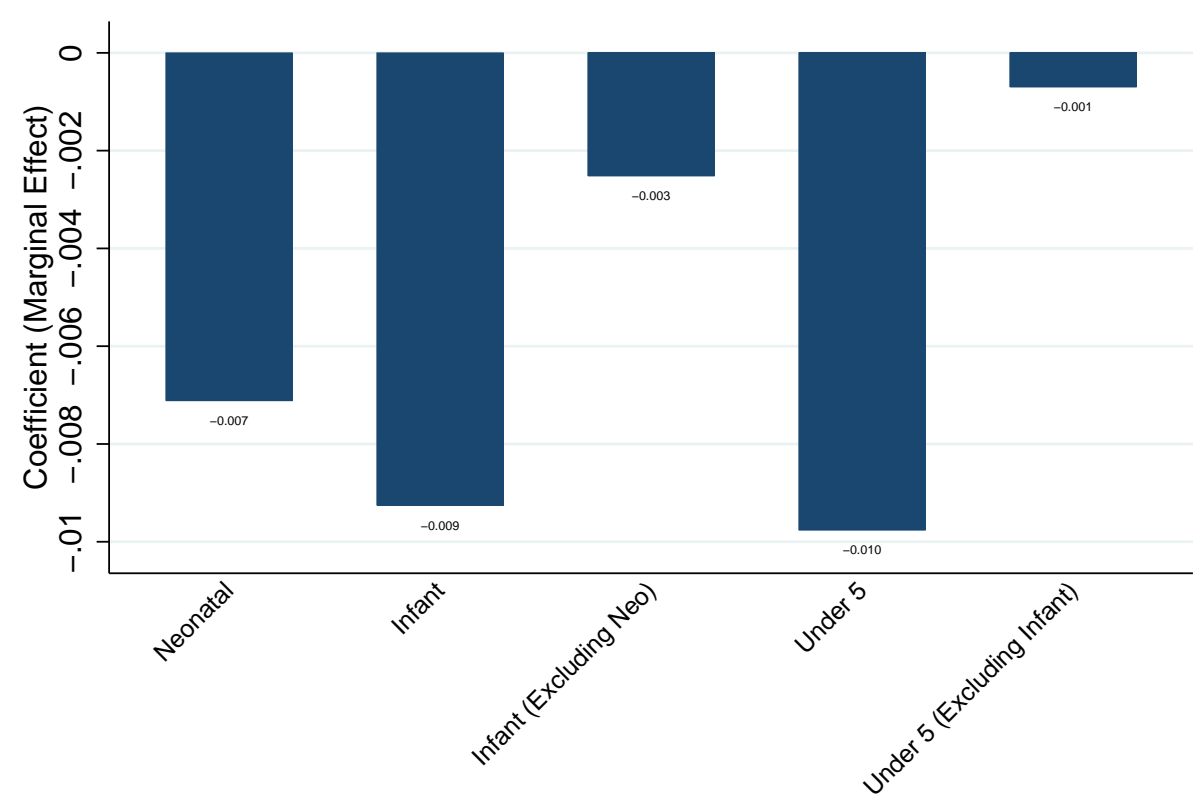

Source: DHS, Total N=561,999

Note: The model shows the marginal effect of a $200 \mathrm{~g}$ increase on the outcome at $2,500 \mathrm{~g}$ estimated using a quadratic specification for birth weight for observations with birth weight data.

\section{Mortality Selection}

For the health outcomes considered, there is a selection problem, as we only observe the status of those children who survive. Given that we expect mortality to be higher among infants with low birth weight, and for them to have been in worse health had they survived, the assumption of missing at random is clearly not appropriate in this case, and could potentially bias estimates of the effect of birth weight. The main concern here is that the effect of birth weight could be underestimated because (some of) the worst affected children are excluded from the data due to mortality (McGovern and Canning 2015). This issue has been widely 
studied in the treatment effects framework in labour economics, for example when wages are not observed due to absence from the job market. Considering the case of a continuous health outcome as a function of a binary treatment allows the adoption of the methodology applied in this literature. For example, when we wish to estimate the effect of birth weight on height for age, the underlying distribution is latent because we only observe the outcome for those who survive:

\author{
Height for Age ${ }^{*}=\alpha_{1}+H B W \beta+\mu$ \\ Survival $^{*}=\alpha_{2}+H B W \theta+\epsilon$ \\ Height for Age $=\mathrm{I}\left[\right.$ Survival $\left.^{*} \geq 0\right]$. Height for Age* $(7)$
}

Where $I[$.$] is the indicator variable. Propensity to survive \left(\right.$ Survival $\left.^{*}\right)$ is another latent variable which is also determined by birth weight. It is more intuitive to think of the treatment having a positive effect on survival, high birth weight (HBW) defined as $B W \geq 2,500 g$, however the same argument applies where low birth weight is the treatment.

In this context, as in many others involving non-random sample selection, selection bias has the potential to substantially affect results (Bareinboim et al. 2014). Heckman (1979) proposes a two-step correction based on the assumption of joint normality of the error terms ( $\mu$ and $\epsilon$ ). Intuitively, the Heckman approach is to estimate the probability of sample inclusion in a first stage, and then adjust for this probability in the outcome equation. Doing so means that estimation of the properly adjusted outcome equation now no longer involves conditioning on a collider (here, mortality), which would ordinarily result in bias (Pearl 2013). Formally, this model is identified under the joint normality and linearity assumptions, although in practice, Heckman type selection models require an exclusion restriction for consistency (Madden 2008). Unfortunately, in this application it is problematic to conceive of a variable which would predict mortality and not underlying health.

Given the absence of a suitable selection variable, an alternative is to adopt a bounding approach. Lee (2009) uses the insight that the outcome we observe (for those who survive) for those receiving the treatment of high birth weight is a weighted average of the mean among two subgroups, the mean among those (inframarginal) individuals who would have survived regardless of treatment (even if they had been low birth weight), and the mean among those (marginal) individuals who were induced to survive by not receiving the treatment 
(and would have died if they had been low birth weight).

$$
\begin{aligned}
& \text { E }\left[\text { Height for Age } \mid \text { High Birth Weight }=1 \text {, Survival }{ }^{*} \geq 0\right]= \\
& (1-p) \text { E }\left[\text { Height for Age } \mid \text { High Birth Weight }=1, \epsilon \geq-\alpha_{2}\right] \\
& \left.+ \text { (p) E[ Height for Age | High Birth Weight }=1,-\alpha_{2}-\theta \leq \epsilon<-\alpha_{2}\right] \text { (8) }
\end{aligned}
$$

The weights $p$ are defined by the proportion of marginal individuals who are only in the observed sample as a result of not being low birth weight:

$$
\mathrm{p}=\frac{\operatorname{Pr}\left[-\alpha_{2}-\theta \leq \epsilon<-\alpha_{2}\right]}{\operatorname{Pr}\left[-\alpha_{2}-\theta \leq \epsilon\right]}(9)
$$

Then if the mean for the inframarginals was observed, it would be possible to estimate the treatment effect of high birth weight $(\beta)$, because the mean among this group is defined by:

$$
\begin{gathered}
\mathrm{E}\left[\text { Height for Age } \mid \text { High Birth Weight }=1, \epsilon \geq-\alpha_{2}\right]= \\
\alpha_{1}+\beta+E\left[\mu \mid \text { High Birth Weight }=1, \epsilon \geq-\alpha_{2}\right]
\end{gathered}
$$

And the observed population mean for the control group is:

E [ Height for Age | High Birth Weight $=0$, Survival $\left.{ }^{*} \geq 0\right]=$

$$
\alpha_{1}+E\left[\mu \mid \text { High Birth Weight }=0, \epsilon \geq-\alpha_{2}\right](11)
$$

Under the assumption that the error terms in both equations $(\mu, \epsilon)$ are jointly independent of the treatment of high birth weight, an estimate of $\beta$ can be obtained by subtracting Equation 11 from Equation 10, the intuition being that there is no selection effect for the inframarginal group. Although Equation 11 is not 
observed, an upper bound can be obtained by considering the case where the marginal group have the lowest $p$ values of Height for Age, where $p$ is defined by:

$$
\mathrm{p}=\frac{\operatorname{Pr}\left[\text { Survival }^{*} \geq 0 \mid \text { High Birth Weight }=1\right]-\operatorname{Pr}\left[\text { Survival }^{*} \geq 0 \mid \text { High Birth Weight }=0\right]}{\operatorname{Pr}\left[\text { Survival }^{*} \geq 0 \mid \text { High Birth Weight }=1\right]}
$$

And then:

$$
\begin{gathered}
\beta^{U B}=E\left[\text { Height for Age } \mid \text { High Birth Weight }=1, \text { Survival }^{*} \geq 0, \text { Height for Age } \geq \text { Height for Age }{ }_{p}\right] \\
-\mathrm{E}\left[\text { Height for Age } \mid \text { High Birth Weight }=0, \text { Survival }^{*} \geq 0\right] \text { (13) }
\end{gathered}
$$

The first term in Equation 13 is estimated by obtaining the mean height for age in the treatment group removing the lowest $p$ values. It seems reasonable to focus on the upper bound here, given that it is difficult to imagine how being low birth weight could improve health. Similarly though, a lower bound could be obtained by examining the case where those in the marginal group comprise the highest $p$ values of height for age. Lee (2009) shows that this approach of estimating the treatment bounds is $\sqrt{n}$ consistent and asymptotically normal. Moreover, this results holds under more general selection models, provided independence of the treatment (from selection and potential outcomes), and monotonicity of the selection effect given treatment. Random assignment would guarantee the first assumption, however this clearly does not apply to birth weight. Results should be interpreted with this limitation in mind, however, the birth weight estimate is consistently large in magnitude and statistically significant in the twin models.

Table 5 presents upper bounds for the effects of height for age and height for weight using this procedure and the sample with complete birth weight data. It is possible to extend the model presented above to include covariates, although the trimming procedure is then applied within cells of the control variables (which must be categorical), which means that not all covariates can be included. In this case, doing so had little effect on the estimated bounds. There is evidence of negative selection; the prevalence of low birth weight among those who are alive (and have data on health outcomes) is 11\%, compared to $23 \%$ among those who are dead (and have missing data on health outcomes). The OLS model indicates that being low birth weight lowers height for age by .58 standard deviations, while the upper bound for the effect using the trimming procedure indicates that the coefficient could be as high as .82 standard deviations. Similarly for height for weight, the 
OLS model indicates a coefficient of -.45 deviations as the penalty for low birth weight, while the lower bound is estimated at -.68. Therefore, this provides some preliminary indication that the coefficients presented here may underestimate the adverse effects of low birth weight, potentially substantially, depending on the extent of selection induced by mortality.

\section{Conclusions}

This paper provides evidence on the relationship between birth weight and child outcomes in developing countries. The empirical approach accounts for missing data, measurement error, potential omitted variable bias, and mortality selection. There is clear evidence of an effect of birth weight on mortality, stunting, wasting, and coughing, and to a lesser extent for fever, diarrhoea and anaemia.

Overall, the IV results support the existence of measurement error in the raw data. Once the correction is applied using size at birth as an instrument, results are consistent with important effects of birth weight on child outcomes. This highlights the importance of adjusting for attenuation bias where birth weight is reported by the mother, a phenomenon which is known to be exacerbated in twin and sibling comparisons (Griliches 1979). Models accounting for selection bias due to missing data on children who have died suggest that the effects of low birth weight on health outcomes are underestimated, potentially substantially.

If the children who died were to go on to have poorer health if they had actually survived, then mortality selection could be a mechanism through which selection for fitness is progressed. This type of selection has also been discussed in relation to the association between stressful environment in utero and the proportion of births which are male (Catalano et al. 2015). Demographic transition in the form of reductions in mortality rates, or changes in fertility, could alter this selection process thereby affecting adaptive potential of a population, a phenomenon which has been observed previously (Moorad 2013).

An important limitation of this approach is that although the twin literature typically appeals to differences in nutritional intake as the source of these differences (Alderman et al. 2001; Black et al. 2007; Royer 2009), the extent to which birth weight itself is a causal factor in later outcomes is not clear, nor whether alternative sources of birth weight differences have heterogeneous effects. Timing of exposure to adversity in utero is also likely to be important for later outcomes (Ekamper et al. 2013), From this perspective, it may be better to view the results presented here as indicating the general effect of in utero environment, for which birth weight is likely to be a reasonable proxy. However, recent research using diagnosis of placenta previa as 
Table 5 Treatment Effects of Low Birth Weight Under Mortality Selection Mortality by Low Birth Weight

\begin{tabular}{lcccc}
\hline & \multicolumn{2}{c}{ Alive } & \multicolumn{2}{c}{ Dead } \\
\hline N & $\%$ & $\mathrm{~N}$ & $\%$ \\
LBW & 301,571 & 89.08 & 16,857 & 76.7 \\
Total & 36,980 & 10.92 & 5,122 & 23.3 \\
\hline
\end{tabular}

Selection Model Estimates

\begin{tabular}{|c|c|c|c|c|}
\hline Variables & $\begin{array}{c}\text { OLS } \\
\text { Height for Age }\end{array}$ & $\begin{array}{l}\text { Selection Model } \\
\text { Height for Age }\end{array}$ & $\begin{array}{l}\text { OLS } \\
\text { Height for Weight }\end{array}$ & $\begin{array}{l}\text { Selection Model } \\
\text { Height for Weight }\end{array}$ \\
\hline
\end{tabular}

Low Birth Weight $\quad-0.577^{* * *} \quad-0.456^{* * *}$

$(0.009)$

$(0.008)$

\begin{tabular}{|c|c|c|c|c|}
\hline Upper Bound & & $\begin{array}{c}-0.820^{* * *} \\
(0.010)\end{array}$ & & $\begin{array}{c}-0.684^{* * *} \\
(0.009)\end{array}$ \\
\hline Observations & 338,551 & 360,530 & 333,815 & 355,802 \\
\hline
\end{tabular}

Note: The top panel shows the proportion of children who are alive by low birth weight $(<2,500 \mathrm{~g})$. Those with missing birth weight data are excluded. The bottom panel shows OLS regressions for height for age $\mathrm{Z}$ score and height for weight $\mathrm{Z}$ scores in columns 1 and 3, while upper bound estimates using the Lee (2009) procedure are displayed in columns 2 and 4 . Bootstrap standard errors are shown in parentheses. 
an instrumental variable indicates that birth weight itself may have direct effects, at least on childhood outcomes (Maruyama et al. 2013).

Another limitation of this analysis are that while the twin models can adjust for gestational age, it is not possible to determine whether the effect of birth weight differs according to whether the child is born prematurely. This is an important question from a policy perspective because mortality risk is higher for infants who are both low birth weight and born early. However, it is difficult to envisage a viable identification strategy which could estimate the causal effect of gestational age.

In terms of the adjustment for measurement error, if there are factors which are systematically associated with maternal recall which vary within twin pairs, such as a desire to retrospectively explain current outcomes such as poor health, then the exclusion restriction for the IV will not hold, and this would not remove bias associated with misreporting of birth weight. Similarly, we must assume that the overall distribution of error is random across twin pairs. Therefore, it is important to interpret these results with caution. Finally, due to the absence of data on zygosity, the ability to fully adjust for genetic factors is incomplete. This could potentially affect estimates if there was a genetic confounder. For example, according to the Weinberg rule (Farbmacher et al. 2018) around $50 \%$ of the male twin sample will be monozygotic. This suggests that bounds on the genetic effect could potentially be obtained by comparing single-sex with multi-sex twin pairs. I consider this analysis in the appendix, however the data become very noisy when stratifying the twin sample at this level. Collecting and providing data on zygosity would be valuable for further analysis. A summary of potential interventions targeting birth weight which could be implemented in developing countries are discussed in Bhutta et al. (2008). Birth weight is correlated with many family background characteristics (McGovern 2013), however not all of these factors are open to intervention. Randomised control trials are the ideal way of informing policy makers about the effectiveness of nutritional supplements during pregnancy, and there is some evidence to support this type of approach, although the type of supplement and context are likely to influence the outcome (Ceesay et al. 1997; Christian et al. 2003; Cogswell et al. 2003). The causal determinants of birth weight are beyond the scope of this paper, however ultimately advances may only be achieved via improvements in poverty and education. The recent focus on the importance of the education of women (Duflo 2012), and family planning (Duflo 2012; King et al. 2007; Miller 2010), are likely to have the added benefit of improving birth weight, thus contributing to help more children reach their full developmental potential.

Given the evidence on intergenerational effects of birth weight (Currie and Moretti 2007; Lumey 1992; Victora 
et al. 2008), any improvements in infant health are likely to have additional benefits which accrue over years and decades. Moreover, the evidence linking health to productivity indicates potentially large economic returns to infant health and nutrition (Caulfield et al. 2006; Haddad and Bouis 1991; Hoddinott et al. 2008; McGovern et al. 2017; Maluccio et al. 2009; Strauss 1986; Thomas and Strauss 1997)/ For example, anaemia among women in Sierra Leone is estimated to cost $\$ 19$ million per year (Aguayo et al. 2003). Therefore, results in this paper indicate that investments targeted at raising birth weight are likely to have a substantial long run impact on the affected individuals and societies. 


\section{References}

A. Adhvaryu and A. Nyshadham. Endowments at birth and parents' investments in children. Economic Journal, 126(593): $781-820,2014$.

V. M. Aguayo, S. Scott, and J. Ross. Sierra Leone - investing in nutrition to reduce poverty: a call for action. Public Health Nutrition, 6(07):653-657, 2003.

H. Alderman, J. R. Behrman, V. Lavy, and R. Menon. Child health and school enrollment: A longitudinal analysis. Journal of Human Resources, 36(1):185-205, 2001.

D. Almond and J. Currie. Human Capital Development before Age Five, volume 4 (Part B) of Handbook of Labor Economics, chapter 15, pages 1315-1486. Elsevier, 2011a.

D. Almond and J. Currie. Killing me softly: The fetal origins hypothesis. Journal Of Economic Perspectives, 25(3):153-172, 2011b.

D. Almond and B. Mazumder. Health capital and the prenatal environment: the effect of ramadan observance during pregnancy. American Economic Journal-Applied Economics, 3(4):56, 2011.

D. Almond and B. Mazumder. Fetal origins and parental responses. Annual Review of Economics, 5(1):37-56, 2013.

D. Almond, K. Y. Chay, and D. S. Lee. The costs of low birth weight. Quarterly Journal of Economics, 120(3):1031-1083, 2005.

T. W. Anderson. Estimating linear restrictions on regression coefficients for multivariate normal distributions. Annals of Mathematical Statistics, 22(3):327-351, 1951.

J. D. Angrist and J.-S. Pischke. Mostly harmless econometrics: An empiricist's companion. Princeton University Press, 2008.

O. Ashenfelter and A. Krueger. Estimates of the economic return to schooling from a new sample of twins. American Economic Review, 84(5):1157-1173, 1994.

R. Bajoria, S. R. Sooranna, S. Ward, S. DaSouza, and M. Hancock. Placental transport rather than maternal concentration of amino acids regulates fetal growth in monochorionic twins: implications for fetal origin hypothesis. American Journal of Obstetrics and Gynecology, 185(5):1239-1246, 2001.

Y. Balarajan, U. Ramakrishnan, E. Özaltin, A. H. Shankar, and S. V. Subramanian. Anaemia in low-income and middle-income countries. The Lancet, 378(9809):2123-2135, 2011.

E. Bareinboim and J. Pearl. Causal inference and the data-fusion problem. Proceedings of the National Academy of Sciences, 113(27):7345-7352, 2016.

E. Bareinboim, J. Tian, and J. Pearl. Recovering from Selection Bias in Causal and Statistical Inference. In $A A A I$, pages 2410-2416, 2014.

J. Behrman and M. Rosenzweig. Returns to birthweight. Review of Economics and Statistics, 86(2):586-601, 2004.

J. R. Behrman, M. R. Rosenzweig, and P. Taubman. Endowments and the allocation of schooling in the family and in the marriage market: the twins experiment. Journal of Political Economy, 102(6):1131-1174, 1994.

P. Bharadwaj, J. Eberhard, and C. Neilson. Health at birth, parental investments and academic outcomes. Journal of Labor Economics, 36(2):349-394, 2018.

Z. A. Bhutta, T. Ahmed, R. E. Black, S. Cousens, K. Dewey, E. Giugliani, B. A. Haider, B. Kirkwood, S. S. Morris, H. Sachdev, and the Maternal and Child Undernutrition Study Group. Maternal and child undernutrition 3: What works? interventions for maternal and child undernutrition and survival. The Lancet, 371(9610):417-440, 2008.

R. E. Black, L. H. Allen, Z. A. Bhutta, L. E. Caulfield, M. De Onis, M. Ezzati, C. Mathers, and J. Rivera. Maternal and child undernutrition: global and regional exposures and health consequences. The Lancet, 371(9608):243-260, 2008.

S. Black, P. Devereux, and K. Salvanes. From the cradle to the labor market? The effect of birth weight on adult outcomes. Quarterly Journal of Economics, 122(1):409-439, 2007.

A. Blanc and T. Wardlaw. Monitoring low birth weight: an evaluation of international estimates and an updated estimation procedure. Bulletin of the World Health Organization, 83(3):178-185d, 2005.

C. Blattman and J. Annan. The consequences of child soldiering. Review of Economics and Statistics, 92(4):882-898, 2010. 
M. Blum, C. L. Colvin, and E. McLaughlin. Scarring and selection in the Great Irish Famine. Working Paper 2017-08, QUCEH Working Paper Series, 2017.

J. Bound and G. Solon. Double trouble: on the value of twins-based estimation of the return to schooling. Economics of Education Review, 18(2):169-182, 1999.

J. Bryce, D. Coitinho, I. Darnton-Hill, D. Pelletier, and P. Pinstrup-Andersen. Maternal and child undernutrition: effective action at national level. The Lancet, 371(9611):510-526, 2008.

R. A. Catalano, R. J. Currier, and D. Steinsaltz. Hormonal evidence of selection in utero revisited. American Journal of Human Biology, 27(3):426-431, 2015.

L. E. Caulfield, S. A. Richard, J. A. Rivera, P. Musgrove, and R. E. Black. Stunting, wasting, and micronutrient deficiency disorders. In A. R. Measham, G. Alleyne, A. Mills, P. Musgrove, M. Claeson, D. T. Jamison, D. B. Evans, J. G. Breman, and P. Jha, editors, Disease Control Priorities in Developing Countries (2nd Edition). Oxford University Press, New York, 2006.

S. M. Ceesay, A. M. Prentice, T. J. Cole, F. Foord, L. T. Weaver, E. Poskitt, and R. G. Whitehead. Effects on birth weight and perinatal mortality of maternal dietary supplements in rural gambia: 5 year randomised controlled trial. BMJ, 315(7111): $786,1997$.

Y. Chen and L.-A. Zhou. The long-term health and economic consequences of the 1959-1961 famine in China. Journal of Health Economics, 26(4):659-681, 2007.

J. Choi. Are twins the same? heavily censored semiparametric panel estimation with fixed effects. Mimeo, https://www2.bc.edu/jinyoung-choi/MMB2013Oct19.pdf, 2013.

P. Christian, S. Khatry, J. Katz, E. Pradhan, S. LeClerq, S. Shrestha, R. Adhikari, A. Sommer, and K. West Jr. Effects of alternative maternal micronutrient supplements on low birth weight in rural nepal: double blind randomised community trial. BMJ, 326(7389):571, 2003.

P. Christian, S. E. Lee, M. D. Angel, L. S. Adair, S. E. Arifeen, P. Ashorn, F. C. Barros, C. H. Fall, W. W. Fawzi, and W. Hao. Risk of childhood undernutrition related to small-for-gestational age and preterm birth in low-and middle-income countries. International Journal of Epidemiology, 42(5):1340-1355, 2013.

M. E. Cogswell, I. Parvanta, L. Ickes, R. Yip, and G. M. Brittenham. Iron supplementation during pregnancy, anemia, and birth weight: a randomized controlled trial. American Journal of Clinical Nutrition, 78(4):773-781, 2003.

D. Conley, K. Strully, and N. G. Bennett. A pound of flesh or just proxy? Using twin differences to estimate the effect of birth weight on life chances. NBER Working Paper No.9901, 2003.

D. J. Corsi, M. Neuman, J. E. Finlay, and S. Subramanian. Demographic and Health Surveys: a profile. International Journal of Epidemiology, 41(6):1602-1613, 2012.

J. Currie. Inequality at birth: Some causes and consequences. American Economic Review, 101(3):1-22, 2011.

J. Currie and E. Moretti. Biology as destiny? Short- and long-run determinants of intergenerational transmission of birth weight. Journal of Labor Economics, 25(2), 2007.

J. Currie and T. Vogl. Early-life health and adult circumstance in developing countries. Annual Review of Economics, 5:1-36, 2013.

D. Cutler, W. Fung, M. Kremer, M. Singhal, and T. Vogl. Early-life malaria exposure and adult outcomes: Evidence from malaria eradication in India. American Economic Journal: Applied Economics, 2(2):72-94, 2010.

A. Deaton. The Analysis of Household Surveys: a Microeconometric Approach to Development Policy. World Bank Publications, 1997.

K. G. Dewey and K. Begum. Long-term consequences of stunting in early life. Maternal \& Child Nutrition, 7:5-18, 2011.

O. Doyle, C. P. Harmon, J. J. Heckman, and R. E. Tremblay. Investing in early human development: timing and economic efficiency. Economics \&5 Human Biology, 7(1):1-6, 2009.

E. Duflo. Women empowerment and economic development. Journal of Economic Literature, 50(4):1051-1079, 2012.

P. Ekamper, F. van Poppel, A. Stein, and L. Lumey. Independent and additive association of prenatal famine exposure and intermediary life conditions with adult mortality between age 18-63 years. Social Science E3 Medicine, 2013. 
H. Farbmacher, R. Guber, and J. Vikstrm. Increasing the credibility of the twin birth instrument. Journal of Applied Econometrics, 33(3):457-472, 2018.

D. N. Figlio, J. Guryan, K. Karbownik, and J. Roth. The effects of poor neonatal health on children's cognitive development. American Economic Review, 104(12):39213955, 2014.

J. E. Finlay, E. Özaltin, and D. Canning. The association of maternal age with infant mortality, child anthropometric failure, diarrhoea and anaemia for first births: evidence from 55 low-and middle-income countries. BMJ Open, 1(2), 2011.

P. Glewwe and E. A. Miguel. Handbook of Labor Economics, volume 4, chapter The impact of child health and nutrition on education in less developed countries, pages 3561-3606. Elsevier, 2007.

P. Glewwe, H. G. Jacoby, and E. M. King. Early childhood nutrition and academic achievement: a longitudinal analysis. Journal of Public Economics, 81(3):345-368, 2001.

T. Gørgens, X. Meng, and R. Vaithianathan. Stunting and selection effects of famine: A case study of the great chinese famine. Journal of Development Economics, 97(1):99-111, 2012.

S. Grantham-McGregor, Y. B. Cheung, S. Cueto, P. Glewwe, L. Richter, and B. Strupp. Developmental potential in the first 5 years for children in developing countries. The Lancet, 369(9555):60-70, 2007.

Z. Griliches. Sibling models and data in economics: Beginnings of a survey. Journal of Political Economy, 87(5 Part 2):S37-S64, 1979.

L. Haddad and H. Bouis. The impact of nutritional status on agricultural productivity: wage evidence from the Philippines. Oxford Bulletin of Economics and Statistics, 53(1):45-68, 1991.

J. Hausman. Mismeasured variables in econometric analysis: problems from the right and problems from the left. Journal of Economic Perspectives, 15(4):57-67, 2001.

D. D. Headey. Developmental drivers of nutritional change: A cross-country analysis. World Development, 42:76-78, 2013.

J. J. Heckman. Sample selection bias as a specification error. Econometrica, 47(1):153-161, 1979.

K. Hill, D. You, M. Inoue, M. Z. Oestergaard, and Technical Advisory Group of the United Nations Inter-agency Group for Child Mortality Estimation. Child mortality estimation: Accelerated progress in reducing global child mortality, 1990-2010. PLoS Med, 9(8):e1001303, 2012.

J. Hoddinott, J. A. Maluccio, J. R. Behrman, R. Flores, and R. Martorell. Effect of a nutrition intervention during early childhood on economic productivity in Guatemalan adults. The Lancet, 371(9610):411-416, 2008.

J. Katz, A. C. C. Lee, N. Kozuki, J. E. Lawn, S. Cousens, H. Blencowe, M. Ezzati, Z. A. Bhutta, T. Marchant, B. A. Willey, L. Adair, F. Barros, A. H. Baqui, P. Christian, W. Fawzi, R. Gonzalez, J. Humphrey, L. Huybregts, P. Kolsteren, A. Mongkolchati, L. C. Mullany, R. Ndyomugyenyi, J. K. Nien, D. Osrin, D. Roberfroid, A. Sania, C. Schmiegelow, M. F. Silveira, J. Tielsch, A. Vaidya, S. C. Velaphi, C. G. Victora, D. Watson-Jones, and R. E. Black. Mortality risk in preterm and small-for-gestational-age infants in low-income and middle-income countries: a pooled country analysis. The Lancet, 382 (9890):417-425, 2013.

E. M. King, S. Klasen, and M. Porter. Copenhagen consensus 2008 challenge paper: Women and development. Copenhagen Consensus Center, Copenhagen, 2007.

H.-P. Kohler, J. R. Behrman, and J. Schnittker. Social science methods for twins data: Integrating causality, endowments, and heritability. Biodemography and Social Biology, 57(1):88-141, 2011.

E. L. Korn and B. I. Graubard. Analysis of Health Surveys, volume 323. John Wiley \& Sons, 1999.

L. Kowaleski-Jones and G. J. Duncan. Effects of participation in the wic program on birthweight: Evidence from the national longitudinal survey of youth. American Journal of Public Health, 92(5):799-804, 2002.

J. E. Lawn, S. Cousens, J. Zupan, and the Lancet Neonatal Survival Steering Team. 4 million neonatal deaths: When? Where? Why? The Lancet, 365(9462):891-900, 2005.

J. E. Lawn, J. Zupan, G. Begkoyian, and R. Knippenberg. Newborn survival. In A. R. Measham, G. Alleyne, A. Mills, P. Musgrove, M. Claeson, D. T. Jamison, D. B. Evans, J. G. Breman, and P. Jha, editors, Disease Control Priorities in Developing Countries (2nd Edition). Oxford University Press, New York, 2006. 
A. C. C. Lee, J. Katz, H. Blencowe, S. Cousens, N. Kozuki, J. P. Vogel, L. Adair, A. H. Baqui, Z. A. Bhutta, L. E. Caulfield, P. Christian, S. E. Clarke, M. Ezzati, W. Fawzi, R. Gonzalez, L. Huybregts, S. Kariuki, P. Kolsteren, J. Lusingu, T. Marchant, M. Merialdi, A. Mongkolchati, L. C. Mullany, J. Ndirangu, M.-L. Newell, J. K. Nien, D. Osrin, D. Roberfroid, H. E. Rosen, A. Sania, M. F. Silveira, J. Tielsch, A. Vaidya, B. A. Willey, J. E. Lawn, and R. E. Black. National and regional estimates of term and preterm babies born small for gestational age in 138 low-income and middle-income countries in 2010. The Lancet Global Health, 1(1):e26-e36, 2013.

D. S. Lee. Training, wages, and sample selection: Estimating sharp bounds on treatment effects. Review of Economic Studies, 76(3):1071-1102, 2009.

S. Linnemayr and H. Alderman. Almost random: Evaluating a large-scale randomized nutrition program in the presence of crossover. Journal of Development Economics, 96(1):106-114, 2011.

R. J. Little. Missing-data adjustments in large surveys. Journal of Business Es Economic Statistics, 6(3):287-296, 1988.

G. López-Casasnovas, B. Rivera, and L. Currais. Health and Economic Growth: Findings and Policy Implications. MIT Press, 2005.

L. H. Lumey. Decreased birthweights in infants after maternal in utero exposure to the dutch famine of 1944-1945. Paediatric and Perinatal Epidemiology, 6(2):240-253, 1992.

D. Madden. Sample selection versus two-part models revisited: The case of female smoking and drinking. Journal of Health Economics, 27(2):300-307, 2008.

J. A. Maluccio, J. Hoddinott, J. R. Behrman, R. Martorell, A. R. Quisumbing, and A. D. Stein. The impact of improving nutrition during early childhood on education among Guatemalan adults. Economic Journal, 119(537):734-763, 2009.

S. Maruyama, E. Heinesen, and C. K. Denmark. Understanding returns to birthweight. Mimeo, http://www.eeaesem.com/files/papers/eea-esem/2013/1537/130215UnderstaindingBW.pdf, 2013.

M. McEniry. Early-life conditions and older adult health in low-and middle-income countries: a review. Journal of Developmental Origins of Health and Disease, 4(1):10-29, 2013.

M. McEniry and A. Palloni. Early life exposures and the occurrence and timing of heart disease among the older adult Puerto Rican population. Demography, 47(1):23-43, 2010.

M. E. McGovern. Still unequal at birth: Birth weight, socioeconomic status and outcomes at age 9 . Economic and Social Review, 44(1):53-84, 2013.

M. E. McGovern and D. Canning. Vaccination and All Cause Child Mortality 1985-2011: Global Evidence from the Demographic and Health Surveys. American Journal of Epidemiology, 182(9):791-798, 2015.

M. E. McGovern, A. Krishna, V. Aguayo, and S. Subramanian. A Review of the Evidence Linking Child Stunting to Economic Outcomes. International Journal of Epidemiology, 46(4):1171-1191, 2017.

G. Miller. Contraception as development? New evidence from family planning in Colombia. Economic Journal, 120(545): 709-736, 2010.

J. A. Moorad. A demographic transition altered the strength of selection for fitness and age-specific survival and fertility in a 19th century American population. Evolution, 67(6):1622-1634, 2013.

L. Moreno and N. Goldman. An assessment of survey data on birthweight. Social Science $\&$ Medicine, 31(4):491-500, 1990.

S. Öberg, S. Cnattingius, S. Sandin, P. Lichtenstein, R. Morley, and A. N. Iliadou. Twinship influence on morbidity and mortality across the lifespan. International Journal of Epidemiology, 41(4):1002-1009, 2012.

P. Oreopoulos, M. Stabile, R. Walld, and L. L. Roos. Short-, medium-, and long-term consequences of poor infant health an analysis using siblings and twins. Journal of Human Resources, 43(1):88-138, 2008.

J. J. O'Sullivan, M. S. Pearce, and L. Parker. Parental recall of birth weight: how accurate is it? Archives of Disease in Childhood, 82(3):202-203, 2000.

J. Pearl. Linear models: A useful "microscope" for causal analysis. Journal of Causal Inference, 1(1):155-170, 2013.

J. K. Rajaratnam, J. R. Marcus, A. D. Flaxman, H. Wang, A. Levin-Rector, L. Dwyer, M. Costa, A. D. Lopez, and C. J. Murray. Neonatal, postneonatal, childhood, and under-5 mortality for 187 countries, 1970-2010: a systematic analysis of progress towards Millennium Development Goal 4. The Lancet, 375(9730):1988-2008, 2010. 
M. R. Rosenzweig and J. Zhang. Do population control policies induce more human capital investment? Twins, birth weight and China's one-child policy. Review of Economic Studies, 76(3):1149-1174, 2009.

M. R. Rosenzweig and J. Zhang. Economic growth, comparative advantage, and gender differences in schooling outcomes: evidence from the birthweight differences of Chinese twins. Journal of Development Economics, 2013.

H. Royer. Separated at girth: US twin estimates of the effects of birth weight. American Economic Journal: Applied Economics, $1(1): 49-85,2009$.

D. B. Rubin. Multiple imputation for nonresponse in surveys, volume 307. John Wiley \& Sons, 2009.

L. C. Schulz. The Dutch Hunger Winter and the developmental origins of health and disease. Proceedings of the National Academy of Sciences, 107(39):16757-16758, 2010.

J. Strauss. Does better nutrition raise farm productivity? Journal of Political Economy, 94(2):297-320, 1986.

M. A. Subramanyam, L. K. Ackerson, and S. Subramanian. Patterning in birthweight in India: analysis of maternal recall and health card data. PLoS One, 5(7):e11424-, 2010.

A. R. Tate, C. Dezateux, T. J. Cole, and L. Davidson. Factors affecting a mother's recall of her baby's birth weight. International Journal of Epidemiology, 34(3):688-695, 2005.

D. Thomas and J. Strauss. Health and wages: Evidence on men and women in urban Brazil. Journal of Econometrics, 77(1): 159-185, 1997.

F. Torche and G. Echevarria. The effect of birthweight on childhood cognitive development in a middle-income country. International Journal of Epidemiology, 40(4):1008-1018, 2011.

C. G. Victora, L. Adair, C. Fall, P. C. Hallal, R. Martorell, L. Richter, and H. S. Sachdev. Maternal and child undernutrition: consequences for adult health and human capital. The Lancet, 371(9609):340-357, 2008.

S. Vollmer, K. Harttgen, M. A. Subramanyam, J. Finlay, S. Klasen, and S. Subramanian. Association between economic growth and early childhood undernutrition: evidence from 121 demographic and health surveys from 36 low-income and middle-income countries. The Lancet Global Health, 2(4):e225-e234, 2014.

S. P. Walker, T. D. Wachs, J. Meeks Gardner, B. Lozoff, G. A. Wasserman, E. Pollitt, and J. A. Carter. Child development: risk factors for adverse outcomes in developing countries. The Lancet, 369(9556):145-157, 2007.

K. Walton, L. Murray, A. Gallagher, G. Cran, M. Savage, and C. Boreham. Parental recall of birthweight: a good proxy for recorded birthweight? European Journal of Epidemiology, 16(9):793-796, 2000.

WHO. World Health Organisation Anthro for personal computers, version 3.2.2, 2011: Software for assessing growth and development of the world's children. WHO, Geneva, 2011. 
How Much Does Birth Weight Matter for Child Health in Developing Countries? Estimates from Siblings and Twins

\section{Mark E. McGovern}

\section{Appendix}

Additional Figures and Tables

Figure A1 DHS Birth Weight Distribution
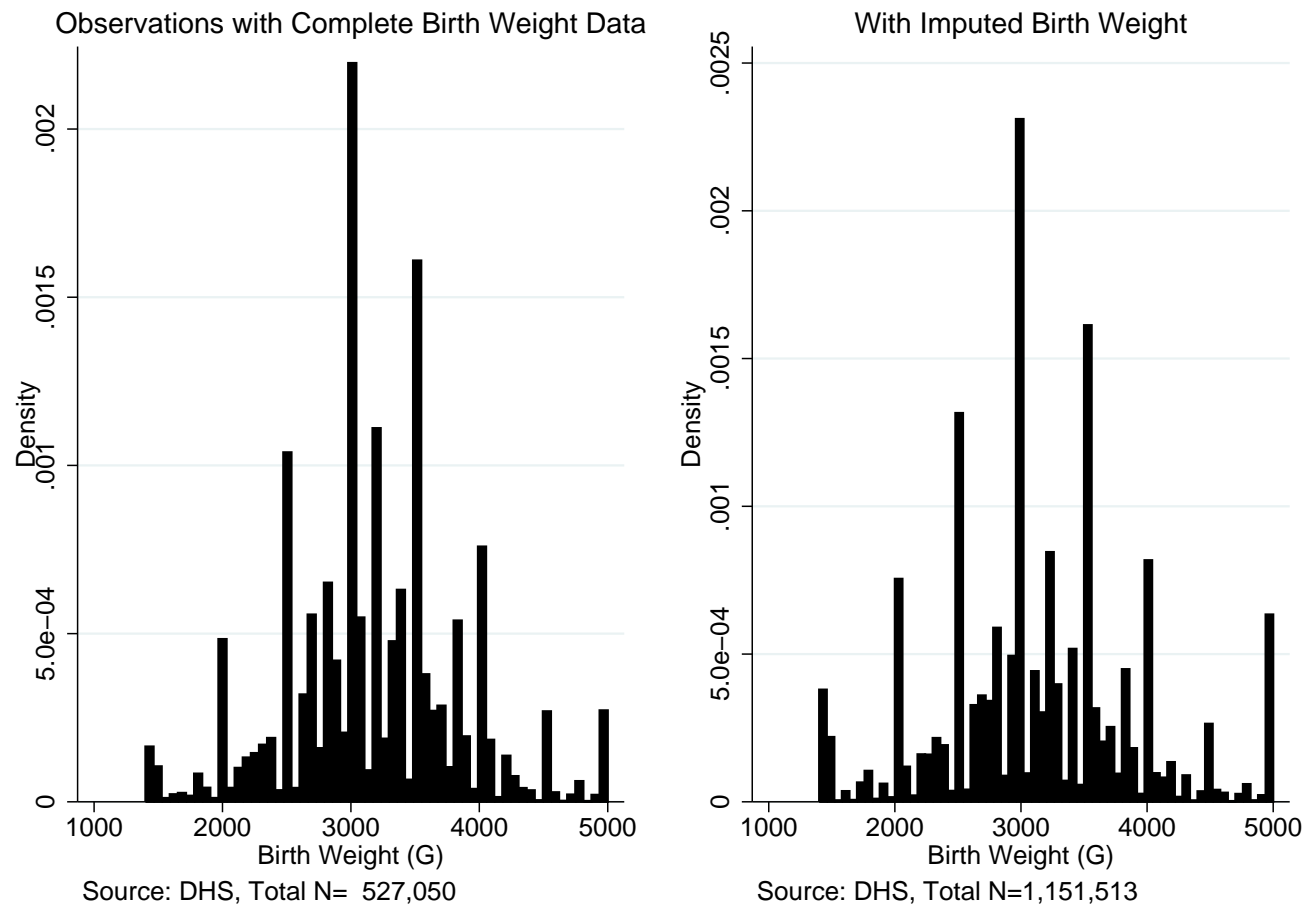
Figure A2 Birth Weight by Reported Size at Birth

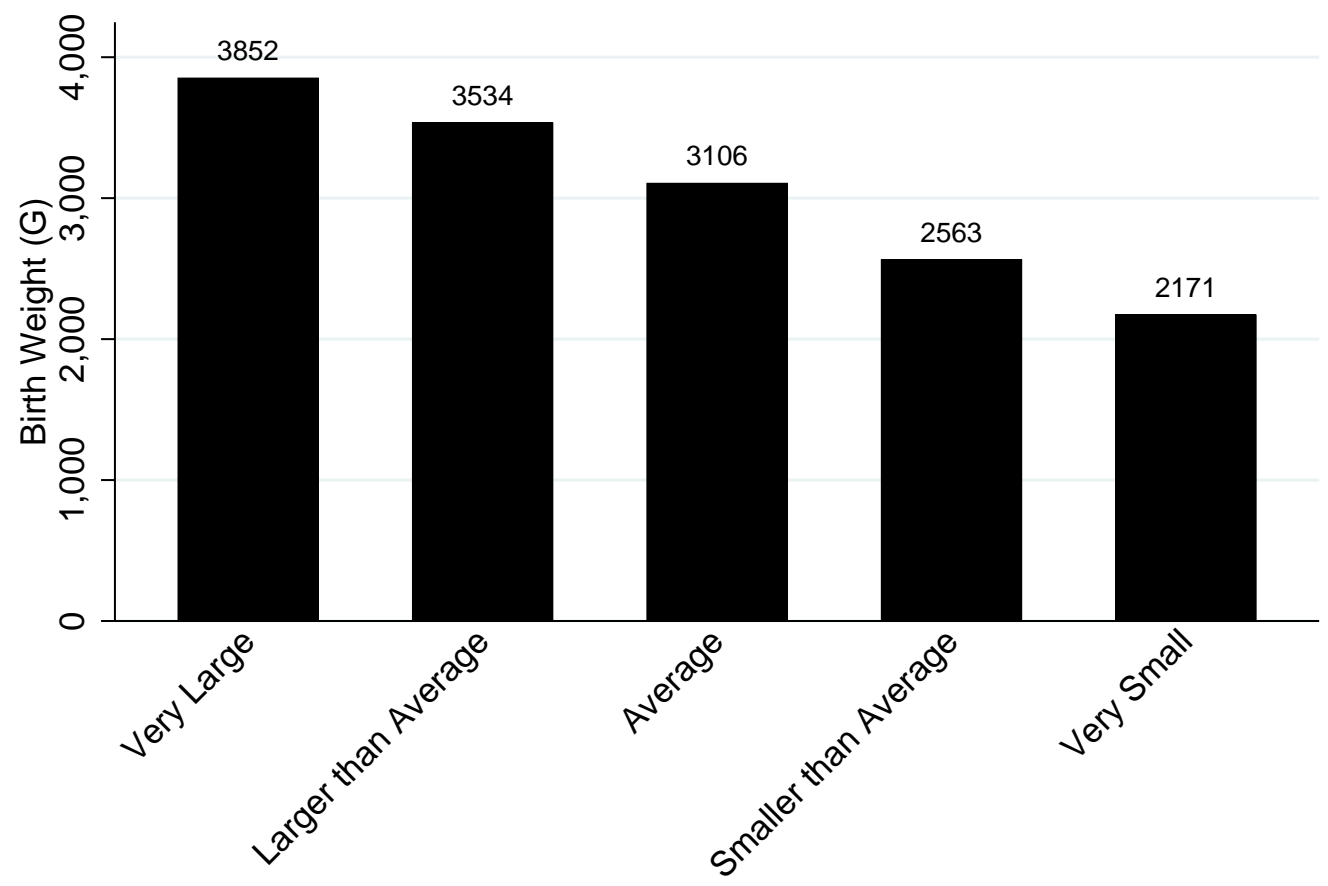

Source: DHS, Total $\mathrm{N}=525,604$

Note: The sample is restricted to those with complete birth weight data. 
Figure A3 Restricted Cubic Spline Models for Birth Weight (Twins)
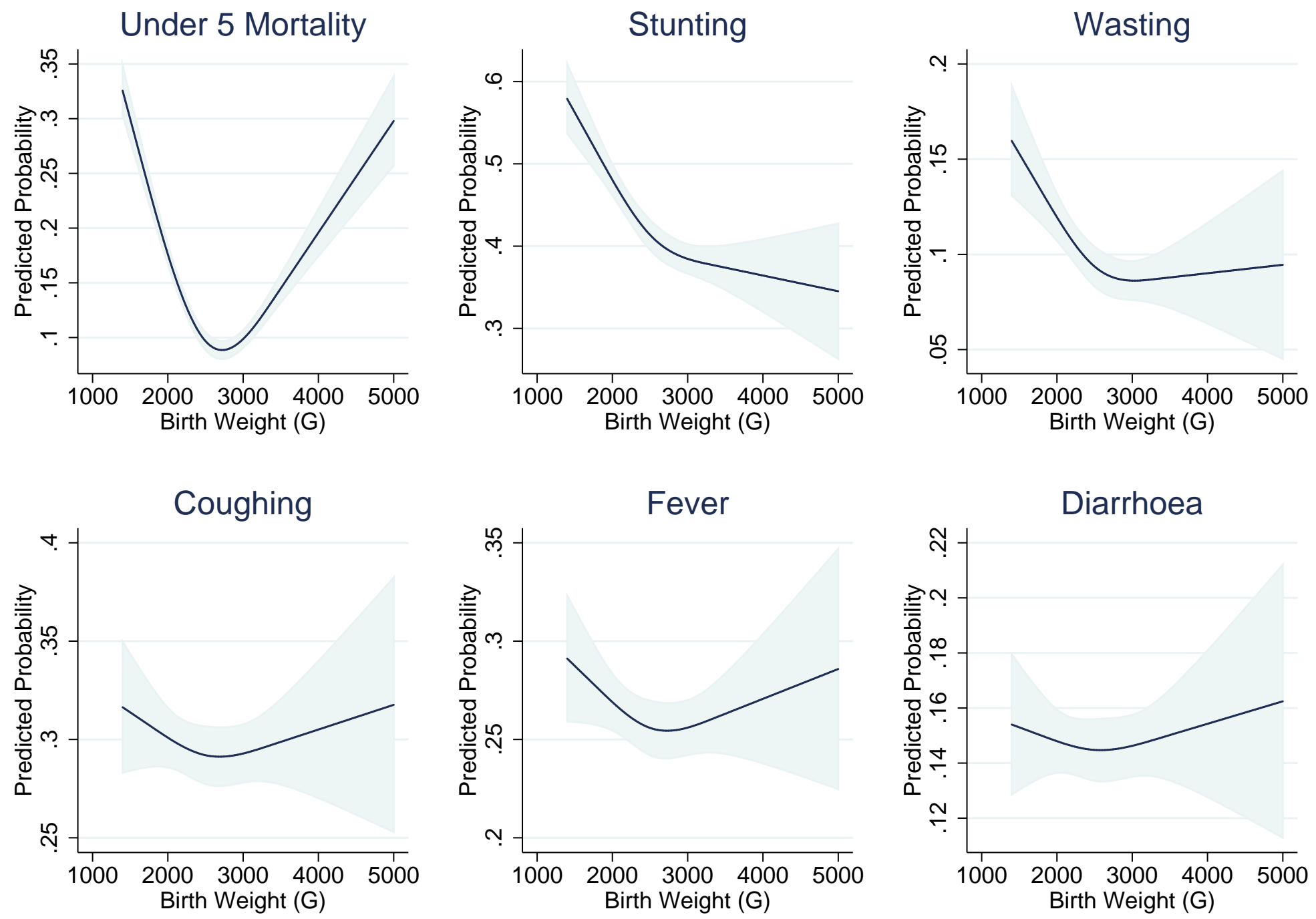

Note: Graph shows the predicted probability of each outcome by birth weight using a restricted cubic spline model with 3 knots. $95 \%$ confidence intervals are shown, and adjusted for clustering at the household level. The sample uses all twins with complete birth weight data. 
Table A1 Sample Characteristics

\begin{tabular}{|c|c|c|c|c|c|c|c|c|}
\hline & \multicolumn{2}{|c|}{ Full Sample } & \multicolumn{2}{|c|}{ Complete BW } & \multicolumn{2}{|c|}{ Siblings } & \multicolumn{2}{|c|}{ Twins } \\
\hline & Mean & $\mathrm{N}$ & Mean & $\mathrm{N}$ & Mean & $\mathrm{N}$ & Mean & $\mathrm{N}$ \\
\hline Birth Weight & $\begin{array}{l}3124.945 \\
(777.844)\end{array}$ & $1,151,513$ & $\begin{array}{l}3166.457 \\
(667.027)\end{array}$ & 527,050 & $\begin{array}{l}3111.137 \\
(789.785)\end{array}$ & 655,587 & $\begin{array}{l}2581.916 \\
(770.062)\end{array}$ & 30,423 \\
\hline Mortality & $\begin{array}{c}0.077 \\
(0.266)\end{array}$ & $1,151,556$ & $\begin{array}{c}0.045 \\
(0.207)\end{array}$ & 527,050 & $\begin{array}{c}0.100 \\
(0.300)\end{array}$ & 655,600 & $\begin{array}{c}0.256 \\
(0.436)\end{array}$ & 30,423 \\
\hline Smaller than Average & $\begin{array}{c}0.193 \\
(0.394)\end{array}$ & $1,134,154$ & $\begin{array}{c}0.163 \\
(0.369)\end{array}$ & 525,604 & $\begin{array}{c}0.202 \\
(0.401)\end{array}$ & 644,055 & $\begin{array}{c}0.410 \\
(0.492)\end{array}$ & 29,769 \\
\hline Stunting & $\begin{array}{c}0.390 \\
(0.488)\end{array}$ & 746,694 & $\begin{array}{c}0.290 \\
(0.454)\end{array}$ & 338,551 & $\begin{array}{c}0.406 \\
(0.491)\end{array}$ & 393,281 & $\begin{array}{c}0.512 \\
(0.500)\end{array}$ & 16,491 \\
\hline Fever & $\begin{array}{c}0.268 \\
(0.443)\end{array}$ & $1,025,331$ & $\begin{array}{c}0.259 \\
(0.438)\end{array}$ & 480,018 & $\begin{array}{c}0.246 \\
(0.431)\end{array}$ & 533,741 & $\begin{array}{c}0.283 \\
(0.450)\end{array}$ & 22,073 \\
\hline Cough & $\begin{array}{c}0.288 \\
(0.453)\end{array}$ & $1,034,954$ & $\begin{array}{c}0.299 \\
(0.458)\end{array}$ & 486,763 & $\begin{array}{c}0.271 \\
(0.445)\end{array}$ & 538,091 & $\begin{array}{c}0.298 \\
(0.458)\end{array}$ & 22,154 \\
\hline Diarrhoea & $\begin{array}{c}0.162 \\
(0.368)\end{array}$ & $1,046,605$ & $\begin{array}{c}0.150 \\
(0.357)\end{array}$ & 494,228 & $\begin{array}{c}0.151 \\
(0.358)\end{array}$ & 544,210 & $\begin{array}{c}0.164 \\
(0.370)\end{array}$ & 22,381 \\
\hline Anaemia & $\begin{array}{c}0.610 \\
(0.488)\end{array}$ & 221,489 & $\begin{array}{c}0.570 \\
(0.495)\end{array}$ & 104,848 & $\begin{array}{c}0.621 \\
(0.485)\end{array}$ & 116,229 & $\begin{array}{c}0.646 \\
(0.478)\end{array}$ & 5,139 \\
\hline Haemoglobin & $\begin{array}{l}104.076 \\
(20.652)\end{array}$ & 214,162 & $\begin{array}{l}105.925 \\
(22.149)\end{array}$ & 100,063 & $\begin{array}{l}103.585 \\
(19.343)\end{array}$ & 112,137 & $\begin{array}{l}101.524 \\
(22.407)\end{array}$ & 4,841 \\
\hline Height for Age & $\begin{array}{r}-1.513 \\
(1.78)\end{array}$ & 746,694 & $\begin{array}{c}-1.159 \\
(1.665)\end{array}$ & 338,551 & $\begin{array}{c}-1.568 \\
(1.782)\end{array}$ & 393,281 & $\begin{array}{l}-2.021 \\
(1.776)\end{array}$ & 16,491 \\
\hline Height for Weight & $\begin{array}{c}-0.157 \\
(1.493)\end{array}$ & 736,822 & $\begin{array}{c}0.072 \\
(1.419)\end{array}$ & 333,823 & $\begin{array}{c}-0.163 \\
(1.488)\end{array}$ & 388,048 & $\begin{array}{c}-0.333 \\
(1.529)\end{array}$ & 16,328 \\
\hline
\end{tabular}

Source: DHS waves 2-6. Complete BW = sample with birth weight data. 
Table A2 Discordance Probabilities for Twins

\begin{tabular}{ccccccc}
\hline \multicolumn{7}{c}{ Size at Birth } \\
\hline & Very Large & Larger & Average & Smaller & Very Small & Total \\
Very Large & 63.51 & 11.22 & 13.43 & 6.48 & 5.37 & 100 \\
Larger & 3.48 & 63.03 & 20.45 & 10.11 & 2.92 & 100 \\
Average & 1.29 & 5.28 & 78.69 & 11.46 & 3.28 & 100 \\
Smaller & 0.92 & 5.13 & 18.12 & 69.62 & 6.21 & 100 \\
Very Small & 1.81 & 3.25 & 7.98 & 12.25 & 74.71 & 100 \\
\hline
\end{tabular}

Mortality

Fever

\begin{tabular}{|c|c|c|c|c|c|c|c|}
\hline & No & Yes & Total & & No & Yes & Total \\
\hline No & 85.35 & 14.65 & 100 & No & 91.78 & 8.22 & 100 \\
\hline Yes & 44.51 & 55.49 & 100 & Yes & 22.59 & 77.41 & 100 \\
\hline
\end{tabular}

Stunting

No $\quad$ Yes $\quad$ Total

No $\quad 081.90 \quad 18$

Yes $\quad \begin{array}{lll}17.98 & 82.02 \quad 100\end{array}$

Cough

No $\quad$ Yes Total

No $\quad 92.76$

Yes 17.81
100

100
Diarrhoea

\begin{tabular}{cccc}
\hline & No & Yes & Total \\
No & 95.13 & 4.87 & 100 \\
Yes & 24.87 & 75.13 & 100 \\
\hline
\end{tabular}

Anaemia

\begin{tabular}{cccc}
\hline & No & Yes & Total \\
No & 66.49 & 33.51 & 100 \\
Yes & 20.16 & 79.84 & 100 \\
\hline
\end{tabular}

Note: Rows show the probability of twin 2 being in a particular category given the category of twin 1, while columns shown the probability of twin 1 being in a particular category given the category of twin 2 . 
Table A3 Reduced Form Estimates for Size at Birth and Under 5 Mortality

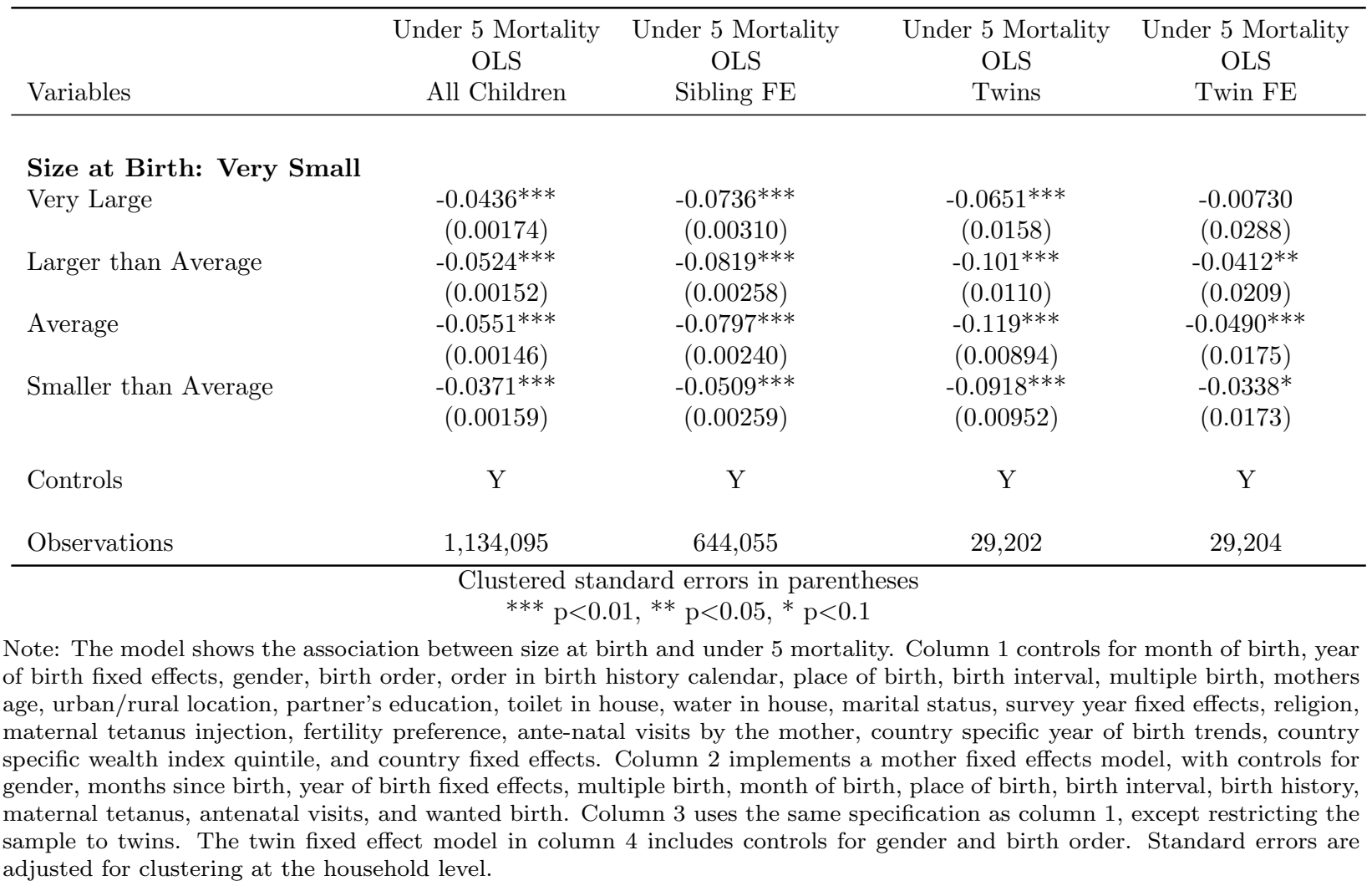


Table A4 Marginal Effect of Birth Weight on Under 5 Mortality for Countries with <50\% Missing

\begin{tabular}{|c|c|c|c|c|}
\hline Variables & OLS Full Sample & Mother IV FE & OLS Full Sample & Mother IV FE \\
\hline & \multicolumn{4}{|c|}{ All Children } \\
\hline Birth Weight & $\begin{array}{c}-0.011^{* * *} \\
(0.000)\end{array}$ & $\begin{array}{c}-0.018^{* * *} \\
(0.001)\end{array}$ & $\begin{array}{c}-0.009 * * * \\
(0.000)\end{array}$ & $\begin{array}{c}-0.017^{* * *} \\
(0.001)\end{array}$ \\
\hline Imputations & No & No & Yes & Yes \\
\hline \multirow[t]{2}{*}{ Observations } & 345,165 & 169,328 & 499,685 & 261,857 \\
\hline & \multicolumn{4}{|c|}{ Twins } \\
\hline Birth Weight & $\begin{array}{c}-0.017^{* * *} \\
(0.002)\end{array}$ & $\begin{array}{c}-0.014^{* * *} \\
(0.005)\end{array}$ & $\begin{array}{c}-0.015^{* * *} \\
(0.001)\end{array}$ & $\begin{array}{c}-0.014^{* * *} \\
(0.004)\end{array}$ \\
\hline Imputations & No & No & Yes & Yes \\
\hline Observations & 8,905 & 8,680 & 12,812 & 12,432 \\
\hline
\end{tabular}

Note: The model shows the marginal effect of a $200 \mathrm{~g}$ increase on the outcome at $2,500 \mathrm{~g}$ estimated using a quadratic specification for birth weight. The sample is restricted to children in countries with less than $<50 \%$ missing data on birth weight. Columns 1 and 3 include controls for month of birth, year of birth fixed effects, gender, birth order, order in birth history calendar, place of birth, birth interval, multiple birth, mothers age, urban/rural location, partner's education, toilet in house, water in house, marital status, survey year fixed effects, religion, maternal tetanus injection, fertility preference, ante-natal visits by the mother, country specific year of birth trends, country specific wealth index quintile, and country fixed effects. Columns 2 and 4 implement the mother fixed effects model, with controls for gender, months since birth, year of birth fixed effects, multiple birth, month of birth, place of birth, birth interval, birth history, maternal tetanus, antenatal visits, and wanted birth. The second panel uses the same specification, except restricting the sample to twins. The twin fixed effect models include controls for gender and birth order. Standard errors are adjusted for clustering at the household level, as well as for 5 replications in the model which imputes missing data on birth weight and birth weight squared (Rubin 2009). 
Table A5 200g Marginal Effect of Birth Weight on Wasting (at 2,500g)

\begin{tabular}{|c|c|c|c|c|}
\hline Variables & OLS Full Sample & Mother IV FE & OLS Full Sample & Mother IV FE \\
\hline & \multicolumn{4}{|c|}{ All Children } \\
\hline Birth Weight & $\begin{array}{c}-0.007^{* * *} \\
(0.000)\end{array}$ & $\begin{array}{c}-0.008^{* * *} \\
(0.001)\end{array}$ & $\begin{array}{c}-0.003^{* * *} \\
(0.000)\end{array}$ & $\begin{array}{c}-0.012^{* * *} \\
(0.001)\end{array}$ \\
\hline Imputations & No & No & Yes & Yes \\
\hline \multirow[t]{2}{*}{ Observations } & 333,815 & 158,639 & 736,793 & 383,847 \\
\hline & \multicolumn{4}{|c|}{ Twins } \\
\hline Birth Weight & $\begin{array}{c}-0.006^{* * *} \\
(0.002)\end{array}$ & $\begin{array}{c}-0.012^{* * *} \\
(0.004)\end{array}$ & $\begin{array}{c}-0.003^{* * *} \\
(0.001)\end{array}$ & $\begin{array}{c}-0.011^{* * *} \\
(0.004)\end{array}$ \\
\hline Imputations & No & No & Yes & Yes \\
\hline Observations & 7,314 & 7,216 & 13,328 & 13,148 \\
\hline
\end{tabular}

Note: The model shows the marginal effect of a $200 \mathrm{~g}$ increase on the outcome at $2,500 \mathrm{~g}$ estimated using a quadratic specification for birth weight. Columns 1 and 3 include controls for month of birth, year of birth fixed effects, gender, birth order, order in birth history calendar, place of birth, birth interval, multiple birth, mothers age, urban/rural location, partner's education, toilet in house, water in house, marital status, survey year fixed effects, religion, maternal tetanus injection, fertility preference, ante-natal visits by the mother, country specific year of birth trends, country specific wealth index quintile, and country fixed effects. Columns 2 and 4 implement the mother fixed effects model, with controls for gender, months since birth, year of birth fixed effects, multiple birth, month of birth, place of birth, birth interval, birth history, maternal tetanus, antenatal visits, and wanted birth. The second panel uses the same specification, except restricting the sample to twins. The twin fixed effect models include controls for gender and birth order. Standard errors are adjusted for clustering at the household level, as well as for 5 replications in the model which imputes missing data on birth weight and birth weight squared (Rubin 2009). 


\section{Coughing, Fever, Diarrhoea and Anaemia}

Table A7 presents results for coughing. The preferred twin IV fixed effect model implies that a $200 \mathrm{~g}$ increase in birth weight is associated with a reduction of .9 to 1 percentage points in the probability of suffering from coughing in the previous two weeks, as reported by the mother. For fever in Table A8, results are less clear. The twin estimates indicate a smaller reduction (compared to OLS) of between .3 and .4 percentage points, but are not statistically significant. Although, given the inefficiency of the twin models, we cannot reject that OLS and twin estimates are equal. The latter OLS model indicates an effect size of between .04 and .05 percentage points. The results for diarrhoea in Table A6 are similar. The twin IV fixed effect models are not statistically significant, but we cannot reject that they are equal to the complete case OLS estimate of .3 percentage points.

Table A9 illustrates the corresponding estimates for anaemia. Due to the lack of coverage for biomarker measures, and resulting reduced sample size, I only present sibling models. Here, the interpretation is more ambiguous than for the previous cases. The results differ depending on whether the imputed values are used in the estimation or not, perhaps reflecting the reduced sample size. For the full sample, the magnitude of the effect of birth weight on the probability of being anaemic is .4 percentage points per $200 \mathrm{~g}$ in the IV fixed effects model. However, the IV fixed effects coefficient ranges from -.001 to -.007. The confidence interval for this estimate includes the cross sectional estimate for both complete case and cross sectional estimates, although it is statistically different from the IV fixed effects complete case model. Overall, the evidence in favour of an effect of birth weight on these outcomes is not as strong, perhaps reflecting that these biomarkers are only available for a relatively small part of the overall sample. 
Table A6 200g Marginal Effect of Birth Weight on Coughing (at 2,500g)

\begin{tabular}{lcccc}
\hline \multirow{2}{*}{ Variables } & OLS Full Sample & Mother IV FE & OLS Full Sample & Mother IV FE \\
\hline & \multicolumn{5}{c}{ All Children } \\
\cline { 2 - 5 } Birth Weight & $-0.023^{* * *}$ & $-0.003^{* *}$ & $-0.006^{*}$ & $-0.003^{* * *}$ \\
& $(0.002)$ & $(0.001)$ & $(0.003)$ & $(0.001)$ \\
Imputations & No & No & Yes & Yes \\
Observations & 486,745 & 226,559 & $1,034,909$ & $1,023,342$ \\
& & & & \\
\cline { 2 - 5 } Birth Weight & $-0.004^{*}$ & $-0.009^{* *}$ & -0.002 & $-0.010^{* * *}$ \\
& $(0.002)$ & $(0.004)$ & $(0.001)$ & $(0.003)$ \\
Imputations & No & No & Yes & Yes \\
Observations & 10,435 & 10,306 & 18,598 & 18,358 \\
\hline
\end{tabular}

Note: The model shows the marginal effect of a $200 \mathrm{~g}$ increase on the outcome at 2,500g estimated using a quadratic specification for birth weight. Columns 1 and 3 include controls for month of birth, year of birth fixed effects, gender, birth order, order in birth history calendar, place of birth, birth interval, multiple birth, mothers age, urban/rural location, partner's education, toilet in house, water in house, marital status, survey year fixed effects, religion, maternal tetanus injection, fertility preference, ante-natal visits by the mother, country specific year of birth trends, country specific wealth index quintile, and country fixed effects. Columns 2 and 4 implement the mother fixed effects model, with controls for gender, months since birth, year of birth fixed effects, multiple birth, month of birth, place of birth, birth interval, birth history, maternal tetanus, antenatal visits, and wanted birth. The second panel uses the same specification, except restricting the sample to twins. The twin fixed effect models include controls for gender and birth order. Standard errors are adjusted for clustering at the household level, as well as for 5 replications in the model which imputes missing data on birth weight and birth weight squared (Rubin 2009). 
Table A7 200g Marginal Effect of Birth Weight on Fever (at 2,500g)

\begin{tabular}{|c|c|c|c|c|}
\hline Variables & OLS Full Sample & Mother IV FE & OLS Full Sample & Mother IV FE \\
\hline & \multicolumn{4}{|c|}{ All Children } \\
\hline Birth Weight & $\begin{array}{c}-0.005^{* * *} \\
(0.000)\end{array}$ & $\begin{array}{c}-0.004^{* * *} \\
(0.001)\end{array}$ & $\begin{array}{c}-0.002^{* *} \\
(0.001)\end{array}$ & $\begin{array}{c}-0.005^{* * *} \\
(0.001)\end{array}$ \\
\hline Imputations & No & No & Yes & Yes \\
\hline \multirow[t]{2}{*}{ Observations } & 480,000 & 223,843 & $1,025,285$ & 527,226 \\
\hline & \multicolumn{4}{|c|}{ Twins } \\
\hline Birth Weight & $\begin{array}{c}-0.004^{* *} \\
(0.002)\end{array}$ & $\begin{array}{l}-0.004 \\
(0.004)\end{array}$ & $\begin{array}{l}-0.002^{*} \\
(0.001)\end{array}$ & $\begin{array}{l}-0.003 \\
(0.004)\end{array}$ \\
\hline Imputations & No & No & Yes & Yes \\
\hline Observations & 10,379 & 10,254 & 19,238 & 18,306 \\
\hline
\end{tabular}

Clustered standard errors in parentheses

$$
* * * \mathrm{p}<0.01,{ }^{*} * \mathrm{p}<0.05,{ }^{*} \mathrm{p}<0.1
$$

Note: The model shows the marginal effect of a $200 \mathrm{~g}$ increase on the outcome at $2,500 \mathrm{~g}$ estimated using a quadratic specification for birth weight. Columns 1 and 3 include controls for month of birth, year of birth fixed effects, gender, birth order, order in birth history calendar, place of birth, birth interval, multiple birth, mothers age, urban/rural location, partner's education, toilet in house, water in house, marital status, survey year fixed effects, religion, maternal tetanus injection, fertility preference, ante-natal visits by the mother, country specific year of birth trends, country specific wealth index quintile, and country fixed effects. Columns 2 and 4 implement the mother fixed effects model, with controls for gender, months since birth, year of birth fixed effects, multiple birth, month of birth, place of birth, birth interval, birth history, maternal tetanus, antenatal visits, and wanted birth. The second panel uses the same specification, except restricting the sample to twins. The twin fixed effect models include controls for gender and birth order. Standard errors are adjusted for clustering at the household level, as well as for 5 replications in the model which imputes missing data on birth weight and birth weight squared (Rubin 2009). 
Table A8 200g Marginal Effect of Birth Weight on Diarrhoea (at 2,500g)

\begin{tabular}{lcccc}
\hline \multirow{2}{*}{ Variables } & OLS Full Sample & Mother IV FE & OLS Full Sample & Mother IV FE \\
\hline & \multicolumn{5}{c}{ All Children } \\
\cline { 2 - 5 } Birth Weight & $-0.003^{* * *}$ & -0.000 & $-0.001^{* * *}$ & $-0.001^{*}$ \\
& $(0.000)$ & $(0.001)$ & $(0.000)$ & $(0.001)$ \\
Imputations & No & No & Yes & Yes \\
Observations & 494,210 & 229,924 & $1,046,558$ & 537,608 \\
& & & & \\
\cline { 2 - 5 } & & & Twins & \\
Birth Weight & -0.000 & -0.002 & $-0.002^{*}$ & -0.002 \\
Imputations & $(0.002)$ & $(0.003)$ & $(0.001)$ & $(0.003)$ \\
Observations & No & No & Yes & Yes \\
\hline
\end{tabular}

Clustered standard errors in parentheses

$$
\text { *** } \mathrm{p}<0.01,{ }^{* *} \mathrm{p}<0.05, * \mathrm{p}<0.1
$$

Note: The model shows the marginal effect of a $200 \mathrm{~g}$ increase on the outcome at 2,500g estimated using a quadratic specification for birth weight. Columns 1 and 3 include controls for month of birth, year of birth fixed effects, gender, birth order, order in birth history calendar, place of birth, birth interval, multiple birth, mothers age, urban/rural location, partner's education, toilet in house, water in house, marital status, survey year fixed effects, religion, maternal tetanus injection, fertility preference, ante-natal visits by the mother, country specific year of birth trends, country specific wealth index quintile, and country fixed effects. Columns 2 and 4 implement the mother fixed effects model, with controls for gender, months since birth, year of birth fixed effects, multiple birth, month of birth, place of birth, birth interval, birth history, maternal tetanus, antenatal visits, and wanted birth. The second panel uses the same specification, except restricting the sample to twins. The twin fixed effect models include controls for gender and birth order. Standard errors are adjusted for clustering at the household level, as well as for 5 replications in the model which imputes missing data on birth weight and birth weight squared (Rubin 2009). 
Table A9 200g Marginal Effect of Birth Weight on Anaemia (at 2,500g)

\begin{tabular}{|c|c|c|c|c|}
\hline Variables & OLS Full Sample & Mother IV FE & OLS Full Sample & Mother IV FE \\
\hline & \multicolumn{4}{|c|}{ All Children } \\
\hline Birth Weight & $\begin{array}{c}-0.004^{* * *} \\
(0.001)\end{array}$ & $\begin{array}{c}-0.007^{* *} \\
(0.004)\end{array}$ & $\begin{array}{c}-0.002^{* * *} \\
(0.001)\end{array}$ & $\begin{array}{l}-0.001 \\
(0.002)\end{array}$ \\
\hline Imputations & No & No & Yes & Yes \\
\hline Observations & 104,845 & 48,267 & 221,484 & 114,401 \\
\hline
\end{tabular}

Note: The model shows the marginal effect of a $200 \mathrm{~g}$ increase on the outcome at $2,500 \mathrm{~g}$ estimated using a quadratic specification for birth weight. Columns 1 and 3 include controls for month of birth, year of birth fixed effects, gender, birth order, order in birth history calendar, place of birth, birth interval, multiple birth, mothers age, urban/rural location, partner's education, toilet in house, water in house, marital status, survey year fixed effects, religion, maternal tetanus injection, fertility preference, ante-natal visits by the mother, country specific year of birth trends, country specific wealth index quintile, and country fixed effects. Columns 2 and 4 implement the mother fixed effects model, with controls for gender, months since birth, year of birth fixed effects, multiple birth, month of birth, place of birth, birth interval, birth history, maternal tetanus, antenatal visits, and wanted birth. Standard errors are adjusted for clustering at the household level, as well as for 5 replications in the model which imputes missing data on birth weight and birth weight squared (Rubin 2009). 


\section{Robustness Checks Among Twins}

As outlined in Section 2, there are a number of limitations to twin studies which potentially affect the interpretation of results from these models. For example, the extent to which the observed effects have external validity for singleton births is not clear. However, for most outcomes studied in this paper, the effect of birth weight in the twin sample (without fixed effects) was broadly similar to that in singletons. In addition, there is existing evidence that twins are comparable to the wider population conditional on survival past the first year (Öberg et al. 2012). Another concern is that zygosity is unknown in most data sets. Therefore, it is difficult to rule out genetics effects, given that dizygotic (non-identical) twins share the same amount of genetic material as siblings (on average, 50\%). However, it is still possible to determine, to a certain extent, whether these genetic endowments are affecting estimates by stratifying the sample according to sex composition. Because mixed sex pairs are dizygotic by definition, we would expect to see a difference between estimates in this group and the same sex group if genetic differences were important. Table A10 presents results for the twin sample where the model for mortality is stratified according to different attributes. I compare the linear probability model with the IV fixed effects model, and I present confidence intervals in brackets.

Following Deaton (1997), I do not weight regressions as the weighted estimator is not typically consistent, however, the first panel illustrates that adjusting for sampling weights has little effect on estimates. The second panel shows the analysis stratified according to sex composition. The fixed effect coefficient in the mixed sample is lower, however the confidence intervals are wide and overlapping in all cases, and we cannot reject that the coefficient in any particular group is different from the pooled estimate. The increased standard errors are likely a reflection of the reduction in sample size. Comparing the coefficients for males and females within mixed pairs gives similar results. The third panel allows for the effect of birth weight to vary according to birth order, as recent research on twins in the US has suggested heterogeneous effects (Choi 2013). However, birth order is potentially an outcome of birth weight, and so it is not necessarily clear that it is appropriate to either condition on, or interact this variable with birth weight, particularly if the view is taken that birth weight is a proxy for unobserved health in utero. An additional difficulty with these data is that the indicator used is the order reported by the mother in the birth history calendar, which means it is difficult to rule out misclassification. Nevertheless, there is no evidence that the effect of birth weight in this sample differs according to who was born first. The fourth panel stratifies the sample by household wealth index in order to determine whether there is differential investment according to birth weight. For example, families with greater resources may provide greater medical care to disadvantaged children. Finally, the last panel stratifies by differences in birth weight within twin pairs according to whether they are above or below the median discordance $(200 \mathrm{~g})$. There is some indication that the effect is larger among twins with less discordance, although, particularly for the case of the fixed effects estimates, the confidence intervals are too wide to draw concrete conclusions.

In summary, these robustness checks provide little clear evidence that the twin estimates are influenced by genetics or post-natal treatment, at least for the case of mortality. Table A11 presents similar results for stunting. However, these results partly reflect the fact that twin estimates are much less precise when reducing the sample size and amount of variation in birth weight when stratifying. Therefore, additional 
data would be helpful in further establishing whether there is heterogeneity in these effects.

Table A10 Heterogeneity in Twin Birth Weight Effects on Mortality

\begin{tabular}{|c|c|c|c|c|c|c|}
\hline & \multicolumn{3}{|c|}{ OLS } & \multicolumn{3}{|c|}{$\mathrm{FE}$} \\
\hline \multirow[b]{2}{*}{ All } & Unweighted & Weighted & & Unweighted & Weighted & \\
\hline & $\begin{array}{c}-0.018 \\
(-0.020-0.015)\end{array}$ & $\begin{array}{c}-0.018 \\
(-0.021-0.015)\end{array}$ & & $\begin{array}{c}-0.008 \\
(-0.016-0.001)\end{array}$ & $\begin{array}{c}-0.008 \\
(-0.0180 .001)\end{array}$ & \\
\hline $\mathrm{N}$ & 14214 & 14214 & & 13960 & 13960 & \\
\hline \multirow[b]{2}{*}{ Gender } & Male & Female & Mixed & Male & Female & Mixed \\
\hline & $\begin{array}{c}-0.026 \\
(-0.031-0.022)\end{array}$ & $\begin{array}{c}-0.008 \\
(-0.012-0.004)\end{array}$ & $\begin{array}{c}-0.018 \\
(-0.022-0.014)\end{array}$ & $\begin{array}{c}-0.015 \\
(-0.029-0.001)\end{array}$ & $\begin{array}{c}-0.011 \\
(-0.0250 .003)\end{array}$ & $\begin{array}{c}-0.004 \\
(-0.0160 .008)\end{array}$ \\
\hline $\mathrm{N}$ & 4622 & 4453 & 5139 & 4544 & 4372 & 5044 \\
\hline \multirow[b]{2}{*}{ Birth Order } & First & Second & & & & \\
\hline & $\begin{array}{c}-0.022 \\
(-0.025-0.018)\end{array}$ & $\begin{array}{c}-0.014 \\
(-0.017-0.011)\end{array}$ & & & & \\
\hline $\mathrm{N}$ & 7070 & 7144 & & & & \\
\hline \multirow[b]{2}{*}{ Wealth Category } & $\leq$ Median & >Median & & $\leq$ Median & >Median & \\
\hline & $\begin{array}{c}-0.017 \\
(-0.020-0.014)\end{array}$ & $\begin{array}{c}-0.019 \\
(-0.022-0.015)\end{array}$ & & $\begin{array}{c}-0.01 \\
(-0.0200 .001)\end{array}$ & $\begin{array}{c}-0.006 \\
(-0.0170 .005)\end{array}$ & \\
\hline $\mathrm{N}$ & 7672 & 6542 & & 7510 & 6428 & \\
\hline \multirow[b]{2}{*}{ Birth Weight Difference } & $\leq 200 \mathrm{~g}$ & $>200 \mathrm{~g}$ & & $\leq 200 \mathrm{~g}$ & $>200 \mathrm{~g}$ & \\
\hline & $\begin{array}{c}-0.021 \\
(-0.025-0.018)\end{array}$ & $\begin{array}{c}-0.01 \\
(-0.014-0.007)\end{array}$ & & $\begin{array}{c}-0.057 \\
(-0.1530 .039)\end{array}$ & $\begin{array}{c}-0.007 \\
(-0.0140 .001)\end{array}$ & \\
\hline $\mathrm{N}$ & 7968 & 6246 & & 7714 & 6246 & \\
\hline
\end{tabular}

Note: The table shows the marginal effect of a $200 \mathrm{~g}$ increase in birth weight at $2,500 \mathrm{~g}$ on the outcome using linear probability and IV fixed effects models where size at birth is the instrument. The sample is restricted to twins with complete birth weight data. The specification is a quadratic for birth weight. In the first panel, columns 1 and 3 are unweighted, while columns 2 and 4 adjust for sampling weights. The second panel stratifies by sex composition of the twin pair. The third panel stratifies by birth order. Panel 4 stratifies by whether the household was in the median wealth category or lower, while panel 5 stratifies by whether the birth weight difference difference was $200 \mathrm{~g}$ or less. $95 \%$ confidence intervals are shown in parentheses. 
Table A11 Heterogeneity in Twin Birth Weight Effects on Stunting

\begin{tabular}{|c|c|c|c|c|c|c|}
\hline & & OLS & & & $\mathrm{FE}$ & \\
\hline \multirow[b]{2}{*}{ All } & Unweighted & Weighted & & Unweighted & Weighted & \\
\hline & $\begin{array}{c}-0.021 \\
(-0.026-0.016)\end{array}$ & $\begin{array}{c}-0.022 \\
(-0.028-0.016)\end{array}$ & & $\begin{array}{c}-0.02 \\
(-0.031-0.008)\end{array}$ & $\begin{array}{c}-0.018 \\
(-0.030-0.006)\end{array}$ & \\
\hline $\mathrm{N}$ & 7398 & 7398 & & 7350 & 7350 & \\
\hline \multirow[b]{2}{*}{ Gender } & Male & Female & Mixed & Male & Female & Mixed \\
\hline & $\begin{array}{c}-0.025 \\
(-0.035-0.016)\end{array}$ & $\begin{array}{c}-0.017 \\
(-0.025-0.008)\end{array}$ & $\begin{array}{c}-0.022 \\
(-0.029-0.014)\end{array}$ & $\begin{array}{c}-0.038 \\
(-0.063-0.014)\end{array}$ & $\begin{array}{c}-0.006 \\
(-0.0270 .014)\end{array}$ & $\begin{array}{c}-0.022 \\
(-0.039-0.004)\end{array}$ \\
\hline $\mathrm{N}$ & 2286 & 2377 & 2735 & 2276 & 2354 & 2720 \\
\hline \multirow[b]{2}{*}{ Birth Order } & First & Second & & & & \\
\hline & $\begin{array}{c}-0.021 \\
(-0.027-0.015)\end{array}$ & $\begin{array}{c}-0.022 \\
(-0.027-0.016)\end{array}$ & & & & \\
\hline $\mathrm{N}$ & 3689 & 3709 & & & & \\
\hline \multirow[b]{2}{*}{ Wealth Category } & $\leq$ Median & $>$ Median & & $\leq$ Median & $>$ Median & \\
\hline & $\begin{array}{c}-0.022 \\
(-0.029-0.016)\end{array}$ & $\begin{array}{c}-0.02 \\
(-0.026-0.013)\end{array}$ & & $\begin{array}{c}-0.023 \\
(-0.038-0.007)\end{array}$ & $\begin{array}{c}-0.018 \\
(-0.036-0.001) \\
3522\end{array}$ & \\
\hline $\mathrm{N}$ & 3851 & 3547 & & 3810 & 3,548 & \\
\hline \multirow[b]{2}{*}{ Birth Weight Difference } & $\leq 200 \mathrm{~g}$ & $>200 \mathrm{~g}$ & & $\leq 200 \mathrm{~g}$ & $>200 \mathrm{~g}$ & \\
\hline & $\begin{array}{c}-0.025 \\
(-0.031-0.018)\end{array}$ & $\begin{array}{c}-0.018 \\
(-0.024-0.011)\end{array}$ & & $\begin{array}{c}0.018 \\
(-0.0930 .129)\end{array}$ & $\begin{array}{c}-0.02 \\
(-0.032-0.009)\end{array}$ & \\
\hline $\mathrm{N}$ & 3928 & 3470 & & 3880 & 3470 & \\
\hline
\end{tabular}

Note: The table shows the marginal effect of a $200 \mathrm{~g}$ increase in birth weight at 2,500g on the outcome using linear probability and IV fixed effects models where size at birth is the instrument. The sample is restricted to twins with complete birth weight data. The specification is a quadratic for birth weight. In the first panel, columns 1 and 3 are unweighted, while columns 2 and 4 adjust for sampling weights. The second panel stratifies by sex composition of the twin pair. The third panel stratifies by birth order. Panel 4 stratifies by whether the household was in the median wealth category or lower, while panel 5 stratifies by whether the birth weight difference difference was $200 \mathrm{~g}$ or less. $95 \%$ confidence intervals are shown in parentheses. 


\section{First Stage and Full Regression Tables}

Table A12 First Stage Estimates - Full Table

\begin{tabular}{|c|c|c|c|c|c|c|c|c|c|c|}
\hline \multirow[b]{3}{*}{ Variables } & \multicolumn{4}{|c|}{ Under 5 Mortality } & \multicolumn{4}{|c|}{ Stunting } & \multirow{2}{*}{\multicolumn{2}{|c|}{$\begin{array}{c}\text { Anaemia } \\
\text { Sibling IV FE }\end{array}$}} \\
\hline & \multicolumn{2}{|c|}{ Sibling IV FE } & \multicolumn{2}{|c|}{ Twin IV FE } & \multicolumn{2}{|c|}{ Sibling IV FE } & \multicolumn{2}{|c|}{ Twin IV FE } & & \\
\hline & BW & BW SQ & BW & BW SQ & BW & BW SQ & BW & BW SQ & BW & BW SQ \\
\hline \multicolumn{11}{|l|}{ Multiple Birth: Singleton } \\
\hline First of Multiple & $\begin{array}{l}-0.382^{* * *} \\
(0.010)\end{array}$ & $\begin{array}{l}-2.140 * * * \\
(0.065)\end{array}$ & $\begin{array}{l}-0.002 \\
(0.005)\end{array}$ & $\begin{array}{c}0.001 \\
(0.027)\end{array}$ & $\begin{array}{l}-0.392^{* * *} \\
(0.013)\end{array}$ & $\begin{array}{l}-2.203^{* * *} \\
(0.087)\end{array}$ & $\begin{array}{l}-0.014^{*} \\
(0.007)\end{array}$ & $\begin{array}{l}-0.055 \\
(0.037)\end{array}$ & $\begin{array}{l}-0.393^{* * *} \\
(0.025)\end{array}$ & $\begin{array}{c}-2.306 * * * \\
(0.170)\end{array}$ \\
\hline Second of Multiple & $\begin{array}{l}-0.403^{* * *} \\
(0.010)\end{array}$ & $\begin{array}{l}-2.245 * * * \\
(0.064)\end{array}$ & & & $\begin{array}{l}-0.413^{* * *} \\
(0.013)\end{array}$ & $\begin{array}{l}-2.295 * * * \\
\quad(0.086)\end{array}$ & & & $\begin{array}{l}-0.417^{* * *} \\
(0.025)\end{array}$ & $\begin{array}{l}-2.427 * * * \\
(0.170)\end{array}$ \\
\hline Third of Multiple & $\begin{array}{l}-0.485^{* * *} \\
(0.042)\end{array}$ & $\begin{array}{l}-2.619 * * * \\
(0.278)\end{array}$ & & & $\begin{array}{l}-0.438^{* * *} \\
(0.062)\end{array}$ & $\begin{array}{l}-2.282^{* * *} \\
(0.418)\end{array}$ & & & $\begin{array}{c}-0.254^{*} \\
(0.106)\end{array}$ & $\begin{array}{l}-1.376 \\
(0.715)\end{array}$ \\
\hline Fourth of Multiple & $\begin{array}{c}-0.649^{* *} \\
(0.203)\end{array}$ & $\begin{array}{c}-3.567^{* *} \\
(1.355)\end{array}$ & & & & & & & & \\
\hline \multicolumn{11}{|l|}{ Month of Birth: January } \\
\hline February & $\begin{array}{c}0.007 \\
(0.007)\end{array}$ & $\begin{array}{c}0.045 \\
(0.048)\end{array}$ & & & $\begin{array}{c}0.004 \\
(0.009)\end{array}$ & $\begin{array}{c}0.026 \\
(0.061)\end{array}$ & & & $\begin{array}{c}0.033 \\
(0.019)\end{array}$ & $\begin{array}{c}0.217 \\
(0.127)\end{array}$ \\
\hline March & $\begin{array}{c}0.009 \\
(0.011)\end{array}$ & $\begin{array}{c}0.061 \\
(0.072)\end{array}$ & & & $\begin{array}{c}0.009 \\
(0.014)\end{array}$ & $\begin{array}{c}0.051 \\
(0.093)\end{array}$ & & & $\begin{array}{c}0.027 \\
(0.030)\end{array}$ & $\begin{array}{c}0.205 \\
(0.202)\end{array}$ \\
\hline April & $\begin{array}{c}0.017 \\
(0.015)\end{array}$ & $\begin{array}{c}0.122 \\
(0.101)\end{array}$ & & & $\begin{array}{c}0.013 \\
(0.019)\end{array}$ & $\begin{array}{c}0.087 \\
(0.130)\end{array}$ & & & $\begin{array}{c}0.024 \\
(0.043)\end{array}$ & $\begin{array}{c}0.159 \\
(0.287)\end{array}$ \\
\hline May & $\begin{array}{c}0.026 \\
(0.020)\end{array}$ & $\begin{array}{c}0.179 \\
(0.132)\end{array}$ & & & $\begin{array}{c}0.020 \\
(0.025)\end{array}$ & $\begin{array}{c}0.129 \\
(0.169)\end{array}$ & & & $\begin{array}{c}0.031 \\
(0.056)\end{array}$ & $\begin{array}{c}0.200 \\
(0.375)\end{array}$ \\
\hline June & $\begin{array}{c}0.039 \\
(0.024)\end{array}$ & $\begin{array}{c}0.275 \\
(0.163)\end{array}$ & & & $\begin{array}{c}0.031 \\
(0.031)\end{array}$ & $\begin{array}{c}0.201 \\
(0.208)\end{array}$ & & & $\begin{array}{c}0.051 \\
(0.069)\end{array}$ & $\begin{array}{c}0.321 \\
(0.466)\end{array}$ \\
\hline July & $\begin{array}{c}0.039 \\
(0.029)\end{array}$ & $\begin{array}{c}0.278 \\
(0.194)\end{array}$ & & & $\begin{array}{c}0.025 \\
(0.037)\end{array}$ & $\begin{array}{c}0.152 \\
(0.248)\end{array}$ & & & $\begin{array}{c}0.058 \\
(0.083)\end{array}$ & $\begin{array}{c}0.374 \\
(0.557)\end{array}$ \\
\hline August & $\begin{array}{c}0.046 \\
(0.034)\end{array}$ & $\begin{array}{c}0.338 \\
(0.226)\end{array}$ & & & $\begin{array}{c}0.035 \\
(0.043)\end{array}$ & $\begin{array}{c}0.232 \\
(0.288)\end{array}$ & & & $\begin{array}{c}0.049 \\
(0.096)\end{array}$ & $\begin{array}{c}0.313 \\
(0.647)\end{array}$ \\
\hline September & $\begin{array}{c}0.059 \\
(0.039)\end{array}$ & $\begin{array}{c}0.409 \\
(0.257)\end{array}$ & & & $\begin{array}{c}0.046 \\
(0.049)\end{array}$ & $\begin{array}{c}0.289 \\
(0.328)\end{array}$ & & & $\begin{array}{c}0.064 \\
(0.110)\end{array}$ & $\begin{array}{c}0.423 \\
(0.739)\end{array}$ \\
\hline October & $\begin{array}{c}0.065 \\
(0.043)\end{array}$ & $\begin{array}{c}0.458 \\
(0.289)\end{array}$ & & & $\begin{array}{c}0.045 \\
(0.055)\end{array}$ & $\begin{array}{c}0.277 \\
(0.369)\end{array}$ & & & $\begin{array}{c}0.061 \\
(0.123)\end{array}$ & $\begin{array}{c}0.373 \\
(0.830)\end{array}$ \\
\hline November & $\begin{array}{c}0.069 \\
(0.048)\end{array}$ & $\begin{array}{c}0.495 \\
(0.321)\end{array}$ & & & $\begin{array}{c}0.053 \\
(0.061)\end{array}$ & $\begin{array}{c}0.331 \\
(0.409)\end{array}$ & & & $\begin{array}{c}0.073 \\
(0.137)\end{array}$ & $\begin{array}{c}0.468 \\
(0.921)\end{array}$ \\
\hline December & $\begin{array}{c}0.075 \\
(0.053)\end{array}$ & $\begin{array}{c}0.528 \\
(0.353)\end{array}$ & & & $\begin{array}{c}0.054 \\
(0.067)\end{array}$ & $\begin{array}{c}0.336 \\
(0.450)\end{array}$ & & & $\begin{array}{c}0.088 \\
(0.151)\end{array}$ & $\begin{array}{c}0.560 \\
(1.013)\end{array}$ \\
\hline Female & $\begin{array}{c}-0.048^{* * *} \\
(0.002)\end{array}$ & $\begin{array}{c}-0.341 * * * \\
(0.014)\end{array}$ & $\begin{array}{c}-0.038 * * * \\
(0.008)\end{array}$ & $\begin{array}{c}-0.204^{* * *} \\
(0.046)\end{array}$ & $\begin{array}{c}-0.052^{* * *} \\
(0.003)\end{array}$ & $\begin{array}{c}-0.358^{* * *} \\
(0.018)\end{array}$ & $\begin{array}{c}-0.042^{* * *} \\
(0.011)\end{array}$ & $\begin{array}{c}-0.240 * * * \\
(0.062)\end{array}$ & $\begin{array}{c}-0.059 * * * \\
(0.005)\end{array}$ & $\begin{array}{c}-0.412 * * * \\
(0.036)\end{array}$ \\
\hline \multicolumn{11}{|l|}{ Place of Birth: Own Home } \\
\hline Other Home & $\begin{array}{l}-0.009 \\
(0.012)\end{array}$ & $\begin{array}{l}-0.043 \\
(0.081)\end{array}$ & & & $\begin{array}{l}-0.019 \\
(0.017)\end{array}$ & $\begin{array}{l}-0.120 \\
(0.117)\end{array}$ & & & $\begin{array}{c}-0.022 \\
(0.031)\end{array}$ & $\begin{array}{l}-0.151 \\
(0.210)\end{array}$ \\
\hline Government Hospital & $\begin{array}{l}-0.010 \\
(0.006)\end{array}$ & $\begin{array}{l}-0.074 \\
(0.040)\end{array}$ & & & $\begin{array}{l}-0.011 \\
(0.008)\end{array}$ & $\begin{array}{l}-0.077 \\
(0.054)\end{array}$ & & & $\begin{array}{l}-0.018 \\
(0.016)\end{array}$ & $\begin{array}{l}-0.148 \\
(0.108)\end{array}$ \\
\hline Government Clinic & $\begin{array}{c}-0.001 \\
(0.007)\end{array}$ & $\begin{array}{l}-0.035 \\
(0.045)\end{array}$ & & & $\begin{array}{c}-0.005 \\
(0.009)\end{array}$ & $\begin{array}{l}-0.052 \\
(0.061)\end{array}$ & & & $\begin{array}{l}-0.024 \\
(0.017)\end{array}$ & $\begin{array}{l}-0.203 \\
(0.113)\end{array}$ \\
\hline Private Hospital or Clinic & $\begin{array}{l}-0.001 \\
(0.007)\end{array}$ & $\begin{array}{l}-0.015 \\
(0.049)\end{array}$ & & & $\begin{array}{c}-0.004 \\
(0.010)\end{array}$ & $\begin{array}{l}-0.030 \\
(0.066)\end{array}$ & & & $\begin{array}{l}-0.001 \\
(0.019)\end{array}$ & $\begin{array}{l}-0.026 \\
(0.131)\end{array}$ \\
\hline Other & $\begin{array}{c}0.001 \\
(0.017)\end{array}$ & $\begin{array}{c}0.022 \\
(0.117)\end{array}$ & & & $\begin{array}{c}0.016 \\
(0.022)\end{array}$ & $\begin{array}{c}0.123 \\
(0.148)\end{array}$ & & & $\begin{array}{c}0.010 \\
(0.047)\end{array}$ & $\begin{array}{c}0.048 \\
(0.314)\end{array}$ \\
\hline Missing & $\begin{array}{l}-0.047 \\
(0.024)\end{array}$ & $\begin{array}{c}-0.319^{*} \\
(0.162)\end{array}$ & & & $\begin{array}{c}-0.036 \\
(0.029)\end{array}$ & $\begin{array}{l}-0.276 \\
(0.194)\end{array}$ & & & $\begin{array}{l}-0.047 \\
(0.128)\end{array}$ & $\begin{array}{c}0.075 \\
(0.857)\end{array}$ \\
\hline Birth Interval: 1st Birth & & & & & & & & & & \\
\hline 1-11 Months & $\begin{array}{l}-0.012 \\
(0.010)\end{array}$ & $\begin{array}{l}-0.111 \\
(0.065)\end{array}$ & & & $\begin{array}{l}-0.017 \\
(0.014)\end{array}$ & $\begin{array}{l}-0.103 \\
(0.092)\end{array}$ & & & $\begin{array}{l}-0.002 \\
(0.031)\end{array}$ & $\begin{array}{l}-0.019 \\
(0.207)\end{array}$ \\
\hline 12-17 Months & $\begin{array}{c}0.003 \\
(0.005)\end{array}$ & $\begin{array}{l}-0.029 \\
(0.032)\end{array}$ & & & $\begin{array}{l}-0.002 \\
(0.006)\end{array}$ & $\begin{array}{l}-0.057 \\
(0.042)\end{array}$ & & & $\begin{array}{c}0.000 \\
(0.013)\end{array}$ & $\begin{array}{l}-0.057 \\
(0.088)\end{array}$ \\
\hline 18-23 Months & $\begin{array}{c}0.010^{*} \\
(0.004)\end{array}$ & $\begin{array}{c}0.028 \\
(0.028)\end{array}$ & & & $\begin{array}{c}0.007 \\
(0.005)\end{array}$ & $\begin{array}{c}0.011 \\
(0.036)\end{array}$ & & & $\begin{array}{c}0.010 \\
(0.011)\end{array}$ & $\begin{array}{c}0.036 \\
(0.074)\end{array}$ \\
\hline $24+$ Months & $\begin{array}{c}0.017^{* * *} \\
(0.003)\end{array}$ & $\begin{array}{c}0.077^{* * *} * \\
(0.023)\end{array}$ & & & $\begin{array}{c}0.015^{* * *} \\
(0.004)\end{array}$ & $\begin{array}{l}0.066^{*} \\
(0.030)\end{array}$ & & & $\begin{array}{c}0.008 \\
(0.009)\end{array}$ & $\begin{array}{c}0.017 \\
(0.059)\end{array}$ \\
\hline Birth History: 1st & & & & & & & & & & \\
\hline 3 & $\begin{array}{c}0.161 \\
(0.585)\end{array}$ & $\begin{array}{c}3.072 \\
(3.911)\end{array}$ & & & $\begin{array}{c}0.368 \\
(0.619)\end{array}$ & $\begin{array}{c}4.749 \\
(4.144)\end{array}$ & & & & \\
\hline 4 & $\begin{array}{c}0.155 \\
(0.610)\end{array}$ & $\begin{array}{c}0.790 \\
(4.080)\end{array}$ & & & $\begin{array}{c}0.148 \\
(0.589)\end{array}$ & $\begin{array}{c}0.796 \\
(3.943)\end{array}$ & & & & \\
\hline 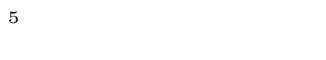 & $\begin{array}{c}0.545 \\
(0.456)\end{array}$ & $\begin{array}{c}3.615 \\
(3.049)\end{array}$ & & & $\begin{array}{c}0.396 \\
(0.502)\end{array}$ & $\begin{array}{c}2.348 \\
(3.355)\end{array}$ & & & & \\
\hline Birth Order: 1st & & & & & & & & & & \\
\hline 2 & $\begin{array}{c}-0.015^{*} \\
(0.007)\end{array}$ & $\begin{array}{c}-0.094^{*} \\
(0.048)\end{array}$ & & & $\begin{array}{l}-0.005 \\
(0.009)\end{array}$ & $\begin{array}{l}-0.047 \\
(0.061)\end{array}$ & & & $\begin{array}{c}0.027 \\
(0.034)\end{array}$ & $\begin{array}{c}0.176 \\
(0.229)\end{array}$ \\
\hline 3 & $\begin{array}{c}-0.032 * * \\
(0.011)\end{array}$ & $\begin{array}{c}-0.198^{* *} \\
(0.076)\end{array}$ & & & $\begin{array}{l}-0.009 \\
(0.015)\end{array}$ & $\begin{array}{l}-0.073 \\
(0.099)\end{array}$ & & & $\begin{array}{c}0.028 \\
(0.042)\end{array}$ & $\begin{array}{c}0.167 \\
(0.284)\end{array}$ \\
\hline 4 & $\begin{array}{l}-0.007 \\
(0.020)\end{array}$ & $\begin{array}{l}-0.056 \\
(0.131)\end{array}$ & & & $\begin{array}{c}0.014 \\
(0.026)\end{array}$ & $\begin{array}{c}0.040 \\
(0.177)\end{array}$ & & & $\begin{array}{c}0.093 \\
(0.068)\end{array}$ & $\begin{array}{c}0.559 \\
(0.457)\end{array}$ \\
\hline
\end{tabular}




\begin{tabular}{|c|c|c|c|c|c|c|c|c|c|c|}
\hline \multirow[b]{3}{*}{ Variables } & \multicolumn{4}{|c|}{ Under 5 Mortality } & \multicolumn{4}{|c|}{ Stunting } & \multirow{2}{*}{\multicolumn{2}{|c|}{$\begin{array}{c}\text { Anaemia } \\
\text { Sibling IV FE }\end{array}$}} \\
\hline & \multicolumn{2}{|c|}{ Sibling IV FE } & \multicolumn{2}{|c|}{ Twin IV FE } & \multicolumn{2}{|c|}{ Sibling IV FE } & \multicolumn{2}{|c|}{ Twin IV FE } & & \\
\hline & BW & BW SQ & BW & BW SQ & BW & BW SQ & BW & BW SQ & BW & BW SQ \\
\hline 5 & $\begin{array}{l}-0.120 \\
(0.064)\end{array}$ & $\begin{array}{c}-1.077^{*} \\
(0.428)\end{array}$ & & & $\begin{array}{c}-0.134 \\
(0.086)\end{array}$ & $\begin{array}{l}-0.935 \\
(0.573)\end{array}$ & & & $\begin{array}{c}0.132 \\
(0.180)\end{array}$ & $\begin{array}{c}0.711 \\
(1.211)\end{array}$ \\
\hline No Maternal Tetanus Shot & $\begin{array}{l}-0.005 \\
(0.004)\end{array}$ & $\begin{array}{l}-0.029 \\
(0.027)\end{array}$ & & & $\begin{array}{c}-0.003 \\
(0.005)\end{array}$ & $\begin{array}{c}-0.021 \\
(0.034)\end{array}$ & & & $\begin{array}{l}-0.018 \\
(0.010)\end{array}$ & $\begin{array}{l}-0.137 \\
(0.070)\end{array}$ \\
\hline Maternal Tetanus Missing & $\begin{array}{l}-0.003 \\
(0.009)\end{array}$ & $\begin{array}{c}-0.004 \\
(0.059)\end{array}$ & & & $\begin{array}{c}0.000 \\
(0.011)\end{array}$ & $\begin{array}{c}0.013 \\
(0.075)\end{array}$ & & & $\begin{array}{c}0.012 \\
(0.023)\end{array}$ & $\begin{array}{c}0.012 \\
(0.153)\end{array}$ \\
\hline Months Since Birth & $\begin{array}{c}0.008 \\
(0.005)\end{array}$ & $\begin{array}{c}0.054 \\
(0.032)\end{array}$ & & & $\begin{array}{c}0.005 \\
(0.006)\end{array}$ & $\begin{array}{c}0.032 \\
(0.041)\end{array}$ & & & $\begin{array}{c}0.005 \\
(0.014)\end{array}$ & $\begin{array}{c}0.034 \\
(0.092)\end{array}$ \\
\hline \multicolumn{11}{|l|}{ Wanted Birth: Before } \\
\hline Later & $\begin{array}{l}-0.004 \\
(0.003)\end{array}$ & $\begin{array}{l}-0.021 \\
(0.022)\end{array}$ & & & $\begin{array}{l}-0.002 \\
(0.004)\end{array}$ & $\begin{array}{l}-0.014 \\
(0.028)\end{array}$ & & & $\begin{array}{c}0.007 \\
(0.008)\end{array}$ & $\begin{array}{c}0.046 \\
(0.057)\end{array}$ \\
\hline No More & $\begin{array}{l}-0.006 \\
(0.005)\end{array}$ & $\begin{array}{l}-0.042 \\
(0.031)\end{array}$ & & & $\begin{array}{l}-0.005 \\
(0.006)\end{array}$ & $\begin{array}{l}-0.043 \\
(0.040)\end{array}$ & & & $\begin{array}{l}-0.003 \\
(0.013)\end{array}$ & $\begin{array}{l}-0.015 \\
(0.089)\end{array}$ \\
\hline Don't Know/Missing & $\begin{array}{l}-0.035 \\
(0.037)\end{array}$ & $\begin{array}{l}-0.166 \\
(0.247)\end{array}$ & & & $\begin{array}{c}0.002 \\
(0.053)\end{array}$ & $\begin{array}{c}0.034 \\
(0.356)\end{array}$ & & & $\begin{array}{c}0.104 \\
(0.118)\end{array}$ & $\begin{array}{c}0.449 \\
(0.796)\end{array}$ \\
\hline \multicolumn{11}{|l|}{ Antenatal Visit: No } \\
\hline Yes & $\begin{array}{c}0.012 \\
(0.008)\end{array}$ & $\begin{array}{c}0.049 \\
(0.053)\end{array}$ & & & $\begin{array}{l}0.022^{*} \\
(0.010)\end{array}$ & $\begin{array}{c}0.127 \\
(0.065)\end{array}$ & & & $\begin{array}{c}-0.006 \\
(0.022)\end{array}$ & $\begin{array}{l}-0.042 \\
(0.146)\end{array}$ \\
\hline Missing & $\begin{array}{c}0.003 \\
(0.012)\end{array}$ & $\begin{array}{l}-0.023 \\
(0.078)\end{array}$ & & & $\begin{array}{c}0.011 \\
(0.015)\end{array}$ & $\begin{array}{c}0.045 \\
(0.098)\end{array}$ & & & $\begin{array}{l}-0.051 \\
(0.036)\end{array}$ & $\begin{array}{l}-0.300 \\
(0.242)\end{array}$ \\
\hline \multicolumn{11}{|l|}{ Size at Birth: Very Small } \\
\hline Very Large & $\begin{array}{c}1.804^{* * *} \\
(0.008)\end{array}$ & $\begin{array}{c}11.148 * * * \\
(0.051)\end{array}$ & $\begin{array}{c}1.462 * * * \\
(0.035)\end{array}$ & $\begin{array}{c}8.284^{* * *} \\
(0.202)\end{array}$ & $\begin{array}{c}1.724^{* * *} \\
(0.010)\end{array}$ & $\begin{array}{c}10.729 * * * \\
(0.070)\end{array}$ & $\begin{array}{c}1.441^{* * *} \\
(0.050)\end{array}$ & $\begin{array}{c}8.168 * * * \\
(0.286)\end{array}$ & $\begin{array}{c}1.769^{* * *} \\
(0.020)\end{array}$ & $\begin{array}{c}10.852^{* * *} \\
(0.136)\end{array}$ \\
\hline Large & $\begin{array}{c}1.383^{* * *} * \\
(0.006)\end{array}$ & $\begin{array}{c}7.887^{* * *} * \\
(0.043)\end{array}$ & $\begin{array}{c}1.165 * * * \\
(0.023)\end{array}$ & $\begin{array}{c}6.098 * * * \\
(0.132)\end{array}$ & $\begin{array}{c}1.316^{* * *} * \\
(0.009)\end{array}$ & $\begin{array}{c}7.597 * * * \\
(0.058)\end{array}$ & $\begin{array}{c}1.094^{* * *} \\
(0.033)\end{array}$ & $\begin{array}{c}5.637 * * * \\
(0.187)\end{array}$ & $\begin{array}{c}1.319^{* * *} \\
(0.018)\end{array}$ & $\begin{array}{c}7.398 * * * \\
(0.119)\end{array}$ \\
\hline Average & $\begin{array}{c}0.894 * * * \\
(0.006)\end{array}$ & $\begin{array}{c}4.498^{* * *} \\
(0.041)\end{array}$ & $\begin{array}{c}0.774 * * * \\
(0.019)\end{array}$ & $\begin{array}{c}3.602 * * * \\
(0.111)\end{array}$ & $\begin{array}{c}0.850 * * * \\
(0.008)\end{array}$ & $\begin{array}{c}4.324^{* * *} \\
(0.055)\end{array}$ & $\begin{array}{c}0.729^{* * *} \\
(0.028)\end{array}$ & $\begin{array}{c}3.352^{* * *} \\
(0.163)\end{array}$ & $\begin{array}{c}0.855 * * * \\
(0.017)\end{array}$ & $\begin{array}{c}4.200 * * * \\
(0.115)\end{array}$ \\
\hline Small & $\begin{array}{c}0.384 * * * \\
(0.007)\end{array}$ & $\begin{array}{c}1.686 * * * \\
(0.044)\end{array}$ & $\begin{array}{c}0.330 * * * \\
(0.018)\end{array}$ & $\begin{array}{c}1.353 * * * \\
(0.107)\end{array}$ & $\begin{array}{c}0.358 * * * \\
(0.009)\end{array}$ & $\begin{array}{c}1.598 * * * \\
(0.059)\end{array}$ & $\begin{array}{c}0.316^{* * *} * \\
(0.028)\end{array}$ & $\begin{array}{c}1.291 * * * \\
(0.158)\end{array}$ & $\begin{array}{c}0.350 * * * \\
(0.018)\end{array}$ & $\begin{array}{c}1.443^{* * *} \\
(0.122)\end{array}$ \\
\hline Partial $F$ & 26274 & 23398 & 992.8 & 885.1 & 13769 & 12402 & 462.7 & 416.9 & 3579 & 3178 \\
\hline Sargan & & & & & & & & & & \\
\hline Sargan $\mathrm{P}$ & 0.0 & $* * *$ & & & & & & & & \\
\hline Anderson LM & & & & & & & & & & \\
\hline Anderson LM P-value & 0.0 & & 0.0 & *** & 0.0 & $* * *$ & & $* * *$ & & $* * *$ \\
\hline Observations & & & 13960 & & & & & & & \\
\hline
\end{tabular}

Note: First stage estimates for birth weight and birth weight squared from models using observations with complete birth weight data are shown. Where they are not part of the fixed effect, the models include controls for year of birth fixed effects, survey year fixed effects, country specific year of birth trends, country specific wealth index quintile and country fixed effects, which are not shown in the table. Standard errors in the OLS model are adjusted for clustering at the household level. The p-value from Anderson's LM test (Anderson 1951), first stage partial $F$ statistics for excluded instruments (size at birth), and Sargan's test for overidentifying restrictions is also shown. 
Table A13 Effects of Birth Weight on Under 5 Mortality and Stunting - Full Table

\begin{tabular}{|c|c|c|c|c|c|c|}
\hline \multirow[b]{2}{*}{ Variables } & \multicolumn{3}{|c|}{ Under 5 Mortality } & \multicolumn{3}{|c|}{ Stunting } \\
\hline & OLS Full Sample & Sibling IV FE & IV FE Twins & OLS Full Sample & Sibling IV FE & IV FE Twins \\
\hline Birth Weight & $\begin{array}{c}-0.168 * * * \\
(0.004)\end{array}$ & $\begin{array}{c}-0.275^{* * *} \\
(0.016)\end{array}$ & $\begin{array}{l}-0.149 \\
(0.131)\end{array}$ & $\begin{array}{c}-0.241 * * * \\
(0.008)\end{array}$ & $\begin{array}{c}-0.338^{* * *} * \\
(0.040)\end{array}$ & $\begin{array}{l}-0.278 \\
(0.199)\end{array}$ \\
\hline Birth Weight Squared & $\begin{array}{c}0.024 * * * \\
(0.001)\end{array}$ & $\begin{array}{c}0.038 * * * \\
(0.003)\end{array}$ & $\begin{array}{c}0.021 \\
(0.024)\end{array}$ & $\begin{array}{c}0.024 * * * \\
(0.001)\end{array}$ & $\begin{array}{c}0.040^{* * *} \\
(0.006)\end{array}$ & $\begin{array}{c}0.036 \\
(0.037)\end{array}$ \\
\hline \multicolumn{7}{|l|}{ Wealth Index: Lowest } \\
\hline Lower & $\begin{array}{c}0.010 \\
(0.007)\end{array}$ & & & $\begin{array}{l}-0.011 \\
(0.017)\end{array}$ & & \\
\hline Middle & $\begin{array}{c}0.009 \\
(0.007)\end{array}$ & & & $\begin{array}{l}-0.025 \\
(0.017)\end{array}$ & & \\
\hline Rich & $\begin{array}{l}-0.000 \\
(0.007)\end{array}$ & & & $\begin{array}{l}-0.048 * * * \\
(0.017)\end{array}$ & & \\
\hline Richest & $\begin{array}{l}-0.008 \\
(0.006)\end{array}$ & & & $\begin{array}{l}-0.100 * * * \\
(0.017)\end{array}$ & & \\
\hline Months Since Birth & $\begin{array}{l}-0.000 \\
(0.000)\end{array}$ & $\begin{array}{l}-0.002 \\
(0.003)\end{array}$ & & $\begin{array}{c}0.005^{* * *} \\
(0.000)\end{array}$ & $\begin{array}{c}0.017^{* * *} \\
(0.007)\end{array}$ & \\
\hline \multicolumn{7}{|l|}{ Multiple Birth: Singleton } \\
\hline First of Multiple & $\begin{array}{c}0.060^{* * *} \\
(0.004)\end{array}$ & $\begin{array}{c}0.043^{* * *} \\
(0.006)\end{array}$ & & $\begin{array}{c}0.070^{* * *} \\
(0.008)\end{array}$ & $\begin{array}{c}0.086^{* * *} \\
(0.014)\end{array}$ & \\
\hline Second of Multiple & $\begin{array}{c}0.068^{* * *} \\
(0.004)\end{array}$ & $\begin{array}{c}0.146^{* * *} \\
(0.006)\end{array}$ & $\begin{array}{c}-0.043^{* * *} \\
(0.005)\end{array}$ & $\begin{array}{c}0.078 * * * \\
(0.007)\end{array}$ & $\begin{array}{c}0.047 * * * \\
(0.014)\end{array}$ & $\begin{array}{l}0.013^{*} \\
(0.007)\end{array}$ \\
\hline Third of Multiple & $\begin{array}{c}0.248^{* * *} \\
(0.043)\end{array}$ & $\begin{array}{c}0.289^{* * *} \\
(0.026)\end{array}$ & & $\begin{array}{l}0.144^{* *} \\
(0.063)\end{array}$ & $\begin{array}{c}0.053 \\
(0.067)\end{array}$ & \\
\hline Fourth of Multiple & $\begin{array}{c}0.634^{* * *} \\
(0.210)\end{array}$ & $\begin{array}{c}0.538^{* * *} \\
(0.126)\end{array}$ & & & & \\
\hline \multicolumn{7}{|l|}{ Month of Birth: January } \\
\hline February & $\begin{array}{l}-0.001 \\
(0.001)\end{array}$ & $\begin{array}{c}0.001 \\
(0.004)\end{array}$ & & $\begin{array}{l}-0.006 \\
(0.004)\end{array}$ & $\begin{array}{l}-0.002 \\
(0.010)\end{array}$ & \\
\hline March & $\begin{array}{l}-0.002 \\
(0.001)\end{array}$ & $\begin{array}{l}-0.001 \\
(0.007)\end{array}$ & & $\begin{array}{l}-0.010 * * * \\
(0.004)\end{array}$ & $\begin{array}{l}-0.000 \\
(0.015)\end{array}$ & \\
\hline April & $\begin{array}{l}-0.001 \\
(0.001)\end{array}$ & $\begin{array}{c}0.003 \\
(0.009)\end{array}$ & & $\begin{array}{l}-0.005 \\
(0.004)\end{array}$ & $\begin{array}{c}0.009 \\
(0.021)\end{array}$ & \\
\hline May & $\begin{array}{l}-0.000 \\
(0.002)\end{array}$ & $\begin{array}{c}0.005 \\
(0.012)\end{array}$ & & $\begin{array}{c}-0.009^{* *} \\
(0.004)\end{array}$ & $\begin{array}{c}0.031 \\
(0.027)\end{array}$ & \\
\hline June & $\begin{array}{c}0.000 \\
(0.002)\end{array}$ & $\begin{array}{c}0.007 \\
(0.015)\end{array}$ & & $\begin{array}{l}-0.007^{*} \\
(0.004)\end{array}$ & $\begin{array}{c}0.046 \\
(0.033)\end{array}$ & \\
\hline July & $\begin{array}{l}-0.000 \\
(0.002)\end{array}$ & $\begin{array}{l}0.007 \\
(0.018)\end{array}$ & & $\begin{array}{c}-0.009^{* *} \\
(0.004)\end{array}$ & $\begin{array}{c}0.053 \\
(0.040)\end{array}$ & \\
\hline August & $\begin{array}{c}0.001 \\
(0.002)\end{array}$ & $\begin{array}{c}0.007 \\
(0.021)\end{array}$ & & $\begin{array}{c}-0.011 * * \\
(0.004)\end{array}$ & $\begin{array}{c}0.058 \\
(0.046)\end{array}$ & \\
\hline September & $\begin{array}{c}-0.004^{* *} \\
(0.002)\end{array}$ & $\begin{array}{l}0.010 \\
(0.024)\end{array}$ & & $\begin{array}{c}-0.009^{* *} \\
(0.004)\end{array}$ & $\begin{array}{c}0.066 \\
(0.053)\end{array}$ & \\
\hline October & $\begin{array}{c}-0.005^{* *} \\
(0.002)\end{array}$ & $\begin{array}{c}0.012 \\
(0.027)\end{array}$ & & $\begin{array}{c}-0.012 * * \\
(0.005)\end{array}$ & $\begin{array}{c}0.085 \\
(0.059)\end{array}$ & \\
\hline November & $\begin{array}{c}-0.003^{*} \\
(0.002)\end{array}$ & $\begin{array}{c}0.010 \\
(0.030)\end{array}$ & & $\begin{array}{l}-0.014 * * * \\
(0.005)\end{array}$ & $\begin{array}{c}0.093 \\
(0.066)\end{array}$ & \\
\hline December & $\begin{array}{l}-0.000 \\
(0.002)\end{array}$ & $\begin{array}{c}0.011 \\
(0.033)\end{array}$ & & $\begin{array}{l}-0.018^{* * *} \\
(0.005)\end{array}$ & $\begin{array}{l}0.098 \\
(0.072)\end{array}$ & \\
\hline Female & $\begin{array}{l}-0.009 * * * \\
(0.001)\end{array}$ & $\begin{array}{l}-0.013^{* * *} \\
(0.001)\end{array}$ & $\begin{array}{l}-0.024 * * * \\
(0.008)\end{array}$ & $\begin{array}{l}-0.051 * * * \\
(0.002)\end{array}$ & $\begin{array}{l}-0.047^{* * *} * \\
\quad(0.003)\end{array}$ & $\begin{array}{c}-0.074 * * * \\
(0.012)\end{array}$ \\
\hline \multicolumn{7}{|c|}{ Place of Birth: Own Home } \\
\hline Other Home & $\begin{array}{l}-0.003 \\
(0.002)\end{array}$ & $\begin{array}{l}-0.007 \\
(0.008)\end{array}$ & & $\begin{array}{c}-0.018^{* *} \\
(0.008)\end{array}$ & $\begin{array}{l}-0.016 \\
(0.019)\end{array}$ & \\
\hline Government Hospital & $\begin{array}{c}0.000 \\
(0.001)\end{array}$ & $\begin{array}{l}-0.005 \\
(0.004)\end{array}$ & & $\begin{array}{l}-0.044 * * * \\
(0.003)\end{array}$ & $\begin{array}{l}-0.007 \\
(0.009)\end{array}$ & \\
\hline Government Clinic & $\begin{array}{c}-0.003^{* *} \\
(0.001)\end{array}$ & $\begin{array}{l}-0.002 \\
(0.004)\end{array}$ & & $\begin{array}{c}-0.034 * * * \\
(0.004)\end{array}$ & $\begin{array}{l}-0.009 \\
(0.010)\end{array}$ & \\
\hline Private Hospital or Clinic & $\begin{array}{l}-0.004 * * * \\
(0.001)\end{array}$ & $\begin{array}{l}-0.018 * * * \\
(0.005)\end{array}$ & & $\begin{array}{c}-0.061 * * * \\
(0.004)\end{array}$ & $\begin{array}{l}-0.016 \\
(0.011)\end{array}$ & \\
\hline Other & $\begin{array}{l}-0.000 \\
(0.004)\end{array}$ & $\begin{array}{l}-0.013 \\
(0.011)\end{array}$ & & $\begin{array}{c}-0.038^{* * *} \\
(0.009)\end{array}$ & $\begin{array}{l}-0.017 \\
(0.024)\end{array}$ & \\
\hline Missing & $\begin{array}{l}-0.006 \\
(0.005)\end{array}$ & $\begin{array}{c}0.005 \\
(0.015)\end{array}$ & & $\begin{array}{c}-0.044 * * * \\
(0.010)\end{array}$ & $\begin{array}{l}-0.007 \\
(0.031)\end{array}$ & \\
\hline \multicolumn{7}{|l|}{ Birth Interval: 1st } \\
\hline 1-11 Months & $\begin{array}{c}0.065^{* * *} \\
(0.006)\end{array}$ & $\begin{array}{c}-0.020 * * * \\
(0.006)\end{array}$ & & $\begin{array}{c}0.068^{* * *} \\
(0.011)\end{array}$ & $\begin{array}{c}0.105^{* * *} \\
(0.015)\end{array}$ & \\
\hline 12-17 Months & $\begin{array}{c}0.030^{* * *} \\
(0.002)\end{array}$ & $\begin{array}{l}-0.001 \\
(0.003)\end{array}$ & & $\begin{array}{c}0.066^{* * *} \\
(0.005)\end{array}$ & $\begin{array}{c}0.070^{* * *} \\
(0.007)\end{array}$ & \\
\hline 18-23 Months & $\begin{array}{c}0.018 * * * \\
(0.002)\end{array}$ & $\begin{array}{c}0.016 * * * \\
(0.003)\end{array}$ & & $\begin{array}{c}0.054 * * * \\
(0.004)\end{array}$ & $\begin{array}{c}0.047 * * * \\
(0.006)\end{array}$ & \\
\hline $24+$ Months & $\begin{array}{l}0.003^{*} \\
(0.002)\end{array}$ & $\begin{array}{l}0.003^{*} \\
(0.002)\end{array}$ & & $\begin{array}{c}0.026 * * * \\
(0.004)\end{array}$ & $\begin{array}{c}0.033^{* * *} \\
(0.005)\end{array}$ & \\
\hline $\begin{array}{l}\text { Birth History: 1st } \\
2\end{array}$ & $\begin{array}{c}-0.003^{*} \\
(0.002)\end{array}$ & & & $\begin{array}{c}-0.011 * * * \\
(0.004)\end{array}$ & & \\
\hline
\end{tabular}




\begin{tabular}{|c|c|c|c|c|c|c|}
\hline \multirow[b]{2}{*}{ Variables } & \multicolumn{3}{|c|}{ Under 5 Mortality } & \multicolumn{3}{|c|}{ Stunting } \\
\hline & OLS Full Sample & Sibling IV FE & IV FE Twins & OLS Full Sample & Sibling IV FE & IV FE Twins \\
\hline 3 & $\begin{array}{l}-0.002 \\
(0.002)\end{array}$ & $\begin{array}{l}-0.125 \\
(0.363)\end{array}$ & & $\begin{array}{l}-0.003 \\
(0.005)\end{array}$ & $\begin{array}{c}-1.858 * * * \\
(0.666)\end{array}$ & \\
\hline 4 & $\begin{array}{c}0.001 \\
(0.002)\end{array}$ & $\begin{array}{l}-0.081 \\
(0.379)\end{array}$ & & $\begin{array}{c}0.011^{* *} \\
(0.005)\end{array}$ & $\begin{array}{c}0.323 \\
(0.634)\end{array}$ & \\
\hline 5 & $\begin{array}{c}0.002 \\
(0.002)\end{array}$ & $\begin{array}{c}0.007 \\
(0.283)\end{array}$ & & $\begin{array}{c}0.036 * * * \\
(0.006)\end{array}$ & $\begin{array}{l}1.229^{* *} \\
(0.539)\end{array}$ & \\
\hline Birth Order: 1st & & & & & & \\
\hline 2 & $\begin{array}{c}0.048 * * * \\
(0.002)\end{array}$ & $\begin{array}{c}0.147 * * * \\
(0.004)\end{array}$ & & $\begin{array}{c}0.024 * * * \\
(0.004)\end{array}$ & $\begin{array}{c}0.001 \\
(0.010)\end{array}$ & \\
\hline 3 & $\begin{array}{c}0.095 * * * \\
(0.003)\end{array}$ & $\begin{array}{c}0.248^{* * *} * \\
(0.007)\end{array}$ & & $\begin{array}{c}-0.035^{* * *} \\
(0.006)\end{array}$ & $\begin{array}{c}-0.091 * * * \\
(0.016)\end{array}$ & \\
\hline 4 & $\begin{array}{c}0.138^{* * *} * \\
(0.012)\end{array}$ & $\begin{array}{c}0.289 * * * \\
(0.012)\end{array}$ & & $\begin{array}{c}-0.072^{* * *} \\
(0.019)\end{array}$ & $\begin{array}{c}-0.138^{* * *} \\
(0.028)\end{array}$ & \\
\hline 0 & $\begin{array}{c}0.196 * * * \\
(0.059)\end{array}$ & $\begin{array}{c}0.279 * * * \\
(0.040)\end{array}$ & & $\begin{array}{l}-0.083 \\
(0.086)\end{array}$ & $\begin{array}{c}-0.183^{* *} \\
(0.092)\end{array}$ & \\
\hline Mother's Age: 15-19 & & & & & & \\
\hline $20-24$ & $\begin{array}{c}-0.006 * * * \\
(0.001)\end{array}$ & & & $\begin{array}{c}-0.017^{* * *} \\
(0.004)\end{array}$ & & \\
\hline $25-29$ & $\begin{array}{c}-0.009 * * * \\
(0.002)\end{array}$ & & & $\begin{array}{c}-0.045^{* * *} \\
(0.004)\end{array}$ & & \\
\hline $30-34$ & $\begin{array}{c}-0.009^{* * *} \\
(0.002)\end{array}$ & & & $\begin{array}{c}-0.062^{* * *} \\
(0.004)\end{array}$ & & \\
\hline $35-39$ & $\begin{array}{c}-0.005 * * * \\
(0.002)\end{array}$ & & & $\begin{array}{c}-0.072 * * * \\
(0.005)\end{array}$ & & \\
\hline $40-44$ & $\begin{array}{c}0.002 \\
(0.002)\end{array}$ & & & $\begin{array}{c}-0.083^{* * *} \\
(0.006)\end{array}$ & & \\
\hline $45-49$ & $\begin{array}{c}0.021^{* * *} \\
(0.004)\end{array}$ & & & $\begin{array}{c}-0.096^{* * *} \\
(0.009)\end{array}$ & & \\
\hline Rural & $\begin{array}{l}-0.001 \\
(0.001)\end{array}$ & & & $\begin{array}{l}0.004^{*} \\
(0.002)\end{array}$ & & \\
\hline Mother's Education: None & & & & & & \\
\hline Primary & $\begin{array}{c}0.001 \\
(0.001)\end{array}$ & & & $\begin{array}{c}-0.030 * * * \\
(0.003)\end{array}$ & & \\
\hline Secondary & $\begin{array}{c}-0.003^{* * *} \\
(0.001)\end{array}$ & & & $\begin{array}{c}-0.064^{* * *} \\
(0.003)\end{array}$ & & \\
\hline Tertiary & $\begin{array}{c}-0.005^{* * *} * \\
(0.002)\end{array}$ & & & $\begin{array}{c}-0.081 * * * \\
(0.004)\end{array}$ & & \\
\hline Don't Know/Missing & $\begin{array}{c}0.011 \\
(0.028)\end{array}$ & & & $\begin{array}{c}-0.099^{*} \\
(0.055)\end{array}$ & & \\
\hline Toilet in House: No & & & & & & \\
\hline Yes & $\begin{array}{l}-0.001 \\
(0.001)\end{array}$ & & & $\begin{array}{c}-0.023^{* * *} * \\
(0.003)\end{array}$ & & \\
\hline Missing & $\begin{array}{c}0.003 \\
(0.003)\end{array}$ & & & $\begin{array}{l}-0.014 \\
(0.010)\end{array}$ & & \\
\hline Water in House: No & & & & & & \\
\hline Yes & $\begin{array}{c}-0.002 * * * \\
(0.001)\end{array}$ & & & $\begin{array}{c}0.001 \\
(0.002)\end{array}$ & & \\
\hline Dantmone Eductione Non & $\begin{array}{c}0.003 \\
(0.004)\end{array}$ & & & $\begin{array}{c}0.002 \\
(0.011)\end{array}$ & & \\
\hline Partner's Education: None & & & & & & \\
\hline Primary & $\begin{array}{l}-0.001 \\
(0.001)\end{array}$ & & & $\begin{array}{c}-0.009 * * * \\
(0.003)\end{array}$ & & \\
\hline Secondary & $\begin{array}{c}-0.004^{* * *} \\
(0.001)\end{array}$ & & & $\begin{array}{c}-0.033^{* * *} \\
(0.003)\end{array}$ & & \\
\hline Tertiary & $\begin{array}{c}-0.005^{* * *} \\
(0.002)\end{array}$ & & & $\begin{array}{c}-0.052 * * * \\
(0.004)\end{array}$ & & \\
\hline Don't Know/Missing & $\begin{array}{l}-0.001 \\
(0.002)\end{array}$ & & & $\begin{array}{c}-0.028 * * * \\
(0.005)\end{array}$ & & \\
\hline Marital Status: Never Married & & & & & & \\
\hline Married & $\begin{array}{c}-0.008^{* * *} \\
(0.002)\end{array}$ & & & $\begin{array}{c}-0.027^{* * *} \\
(0.006)\end{array}$ & & \\
\hline Living Together & $\begin{array}{l}-0.003 \\
(0.002)\end{array}$ & & & $\begin{array}{c}-0.022 * * * \\
(0.006)\end{array}$ & & \\
\hline Widowed & $\begin{array}{c}0.025 * * * \\
(0.004)\end{array}$ & & & $\begin{array}{l}-0.014 \\
(0.010)\end{array}$ & & \\
\hline Divorced & $\begin{array}{c}0.023 * * * \\
(0.004)\end{array}$ & & & $\begin{array}{c}-0.021^{* *} \\
(0.008)\end{array}$ & & \\
\hline Not Living Together & $\begin{array}{c}0.012 * * * \\
(0.003)\end{array}$ & & & $\begin{array}{l}-0.007 \\
(0.007)\end{array}$ & & \\
\hline Religion: Christian & & & & & & \\
\hline Muslim & $\begin{array}{l}0.003^{*} \\
(0.001)\end{array}$ & & & $\begin{array}{c}0.002 \\
(0.004)\end{array}$ & & \\
\hline Jewish & $\begin{array}{c}0.011 \\
(0.008)\end{array}$ & & & $\begin{array}{c}0.004 \\
(0.015)\end{array}$ & & \\
\hline Buddhist & $\begin{array}{c}0.004 \\
(0.004)\end{array}$ & & & $\begin{array}{c}0.011 \\
(0.022)\end{array}$ & & \\
\hline Hindu & $0.005 * * *$ & & & -0.009 & & \\
\hline
\end{tabular}




\begin{tabular}{|c|c|c|c|c|c|c|}
\hline \multirow[b]{2}{*}{ Variables } & \multicolumn{3}{|c|}{ Under 5 Mortality } & \multicolumn{3}{|c|}{ Stunting } \\
\hline & OLS Full Sample & Sibling IV FE & IV FE Twins & OLS Full Sample & Sibling IV FE & IV FE Twins \\
\hline & $(0.002)$ & & & $(0.008)$ & & \\
\hline Sikh & $\begin{array}{c}0.002 \\
(0.007)\end{array}$ & & & $\begin{array}{c}-0.098^{* * *} \\
(0.018)\end{array}$ & & \\
\hline Traditional & $\begin{array}{c}0.000 \\
(0.004)\end{array}$ & & & $\begin{array}{c}0.022^{* *} \\
(0.009)\end{array}$ & & \\
\hline Other & $\begin{array}{c}0.001 \\
(0.003)\end{array}$ & & & $\begin{array}{c}-0.003 \\
(0.008)\end{array}$ & & \\
\hline None & $\begin{array}{l}-0.003 \\
(0.002)\end{array}$ & & & $\begin{array}{l}-0.005 \\
(0.005)\end{array}$ & & \\
\hline Unknown & $\begin{array}{c}0.003 \\
(0.003)\end{array}$ & & & $\begin{array}{c}-0.020 * * * \\
(0.007)\end{array}$ & & \\
\hline Maternal Tetanus Injection: Yes & & & & & & \\
\hline None & $\begin{array}{c}0.006 * * * \\
(0.001)\end{array}$ & $\begin{array}{c}0.016 * * * \\
(0.002)\end{array}$ & & $\begin{array}{c}-0.005^{*} \\
(0.002)\end{array}$ & $\begin{array}{c}-0.014^{* *} \\
(0.005)\end{array}$ & \\
\hline Missing & $\begin{array}{c}0.001 \\
(0.002)\end{array}$ & $\begin{array}{c}0.012^{* *} \\
(0.005)\end{array}$ & & $\begin{array}{c}-0.014^{* * *} \\
(0.005)\end{array}$ & $\begin{array}{c}-0.028^{* *} \\
(0.012)\end{array}$ & \\
\hline Wanted Birth: Before & & & & & & \\
\hline Later & $\begin{array}{c}-0.009^{* * *} \\
(0.001)\end{array}$ & $\begin{array}{c}0.044^{* * *} * \\
(0.002)\end{array}$ & & $\begin{array}{l}0.004^{*} \\
(0.002)\end{array}$ & $\begin{array}{c}-0.018^{* * *} \\
(0.004)\end{array}$ & \\
\hline No More & $\begin{array}{c}-0.008^{* * *} \\
(0.001)\end{array}$ & $\begin{array}{c}0.047^{* * *} * \\
(0.003)\end{array}$ & & $\begin{array}{c}0.010^{* * *} \\
(0.003)\end{array}$ & $\begin{array}{l}-0.008 \\
(0.006)\end{array}$ & \\
\hline Don't Know/Missing & $\begin{array}{c}0.084 * * * \\
(0.017)\end{array}$ & $\begin{array}{c}0.107 * * * \\
(0.023)\end{array}$ & & $\begin{array}{l}-0.008 \\
(0.027)\end{array}$ & $\begin{array}{l}-0.049 \\
(0.057)\end{array}$ & \\
\hline Antenatal Visit: No & & & & & & \\
\hline Yes & $\begin{array}{c}-0.005^{* * *} \\
(0.002)\end{array}$ & $\begin{array}{c}-0.025 * * * \\
(0.005)\end{array}$ & & $\begin{array}{c}-0.034 * * * \\
(0.004)\end{array}$ & $\begin{array}{c}0.008 \\
(0.010)\end{array}$ & \\
\hline Missing & $\begin{array}{c}-0.005 * * \\
(0.002)\end{array}$ & $\begin{array}{c}-0.017^{* *} \\
(0.007)\end{array}$ & & $\begin{array}{c}-0.040^{* * *} \\
(0.006)\end{array}$ & $\begin{array}{c}-0.029^{*} \\
(0.016)\end{array}$ & \\
\hline Constant & $\begin{array}{c}8.260 * * * \\
(1.907)\end{array}$ & $\begin{array}{c}-15.319 * * * \\
\quad(5.472)\end{array}$ & $\begin{array}{c}0.415^{* *} \\
(0.169)\end{array}$ & $\begin{array}{c}14.223^{* * *} \\
(4.948)\end{array}$ & $\begin{array}{c}45.695^{* * *} \\
(11.492)\end{array}$ & $\begin{array}{c}0.922 * * * \\
(0.261)\end{array}$ \\
\hline Observations & 527,027 & 263,214 & 14,214 & 338,540 & 160,804 & 7,398 \\
\hline
\end{tabular}

Note: Birth weight coefficients are multipled by 1000. Models using observations with birth weight data are shown. Where they are not part of the fixed effect, the models include controls for year of birth fixed effects, survey year fixed effects, country specific year of birth trends, country specific wealth index quintile and country fixed effects, which are not shown in the table. Standard errors in the OLS model are adjusted for clustering at the household level. 
Table A14 Effects of Birth Weight on Wasting and Coughing - Full Table

\begin{tabular}{|c|c|c|c|c|c|c|}
\hline \multirow[b]{2}{*}{ Variables } & \multicolumn{3}{|c|}{ Wasting } & \multicolumn{3}{|c|}{ Coughing } \\
\hline & OLS Full Sample & Sibling IV FE & IV FE Twins & OLS Full Sample & Sibling IV FE & IV FE Twins \\
\hline Birth Weight & $\begin{array}{c}-0.076^{* * *} \\
(0.005)\end{array}$ & $\begin{array}{c}-0.084^{* * *} \\
(0.022)\end{array}$ & $\begin{array}{c}-0.109 \\
(0.148)\end{array}$ & $\begin{array}{c}-0.095^{* * *} \\
(0.007)\end{array}$ & $\begin{array}{c}-0.047^{*} \\
(0.027)\end{array}$ & $\begin{array}{c}-0.194 \\
(0.124)\end{array}$ \\
\hline Birth Weight Squared & $\begin{array}{c}0.008^{* * *} \\
(0.001)\end{array}$ & $\begin{array}{c}0.009^{* *} \\
(0.004)\end{array}$ & $\begin{array}{c}0.009 \\
(0.027)\end{array}$ & $\begin{array}{c}0.014^{* * *} \\
(0.001)\end{array}$ & $\begin{array}{c}0.006 \\
(0.004)\end{array}$ & $\begin{array}{c}0.030 \\
(0.023)\end{array}$ \\
\hline \multicolumn{7}{|l|}{ Wealth Index: Lowest } \\
\hline Lower & $\begin{array}{l}-0.016^{*} \\
(0.010)\end{array}$ & & & $\begin{array}{c}0.016 \\
(0.015)\end{array}$ & & \\
\hline Middle & $\begin{array}{c}-0.018^{*} \\
(0.010)\end{array}$ & & & $\begin{array}{l}-0.014 \\
(0.015)\end{array}$ & & \\
\hline Rich & $\begin{array}{l}-0.013 \\
(0.010)\end{array}$ & & & $\begin{array}{l}-0.002 \\
(0.015)\end{array}$ & & \\
\hline Richest & $\begin{array}{c}-0.031 * * * \\
(0.010)\end{array}$ & & & $\begin{array}{l}-0.021 \\
(0.016)\end{array}$ & & \\
\hline Months Since Birth & $\begin{array}{c}-0.003^{* * *} \\
(0.000)\end{array}$ & $\begin{array}{c}0.003 \\
(0.004)\end{array}$ & & $\begin{array}{c}-0.006 * * * \\
(0.000)\end{array}$ & $\begin{array}{l}-0.006 \\
(0.005)\end{array}$ & \\
\hline \multicolumn{7}{|l|}{ Multiple Birth: Singleton } \\
\hline First of Multiple & $\begin{array}{c}0.015^{* * *} \\
(0.005)\end{array}$ & $\begin{array}{c}0.030 * * * \\
(0.008)\end{array}$ & & $\begin{array}{c}0.048 * * * \\
(0.006)\end{array}$ & $\begin{array}{c}0.048^{* * *} \\
(0.010)\end{array}$ & \\
\hline Second of Multiple & $\begin{array}{c}0.022 * * * \\
(0.005)\end{array}$ & $\begin{array}{c}0.013 \\
(0.008)\end{array}$ & $\begin{array}{c}0.016 * * * \\
(0.005)\end{array}$ & $\begin{array}{c}0.012^{* *} \\
(0.006)\end{array}$ & $\begin{array}{l}-0.006 \\
(0.010)\end{array}$ & $\begin{array}{c}0.020^{* * *} \\
(0.005)\end{array}$ \\
\hline Third of Multiple & $\begin{array}{c}0.024 \\
(0.043)\end{array}$ & $\begin{array}{l}-0.003 \\
(0.038)\end{array}$ & & $\begin{array}{c}0.015 \\
(0.053)\end{array}$ & $\begin{array}{l}-0.042 \\
(0.050)\end{array}$ & \\
\hline Fourth of Multiple & & & & $\begin{array}{c}0.821 * * * \\
(0.010)\end{array}$ & $\begin{array}{l}-0.128 \\
(0.364)\end{array}$ & \\
\hline \multicolumn{7}{|l|}{ Month of Birth: January } \\
\hline February & $\begin{array}{l}-0.002 \\
(0.002)\end{array}$ & $\begin{array}{c}0.005 \\
(0.006)\end{array}$ & & $\begin{array}{c}-0.009 * * * \\
(0.003)\end{array}$ & $\begin{array}{l}-0.006 \\
(0.007)\end{array}$ & \\
\hline March & $\begin{array}{l}-0.002 \\
(0.002)\end{array}$ & $\begin{array}{c}0.004 \\
(0.008)\end{array}$ & & $\begin{array}{c}-0.011 * * * \\
(0.003)\end{array}$ & $\begin{array}{l}-0.016 \\
(0.011)\end{array}$ & \\
\hline April & $\begin{array}{c}-0.008 * * * \\
(0.002)\end{array}$ & $\begin{array}{c}0.009 \\
(0.012)\end{array}$ & & $\begin{array}{c}-0.017^{* * *} \\
(0.003)\end{array}$ & $\begin{array}{l}-0.023 \\
(0.015)\end{array}$ & \\
\hline May & $\begin{array}{c}-0.004^{*} \\
(0.002)\end{array}$ & $\begin{array}{c}0.010 \\
(0.015)\end{array}$ & & $\begin{array}{c}-0.027^{* * *} \\
(0.004)\end{array}$ & $\begin{array}{l}-0.024 \\
(0.019)\end{array}$ & \\
\hline June & $\begin{array}{c}-0.009 * * * \\
(0.003)\end{array}$ & $\begin{array}{c}0.017 \\
(0.019)\end{array}$ & & $\begin{array}{c}-0.033^{* * *} \\
(0.004)\end{array}$ & $\begin{array}{l}-0.034 \\
(0.024)\end{array}$ & \\
\hline July & $\begin{array}{c}-0.011^{* * *} \\
(0.003)\end{array}$ & $\begin{array}{c}0.022 \\
(0.022)\end{array}$ & & $\begin{array}{c}-0.039 * * * \\
(0.004)\end{array}$ & $\begin{array}{l}-0.043 \\
(0.029)\end{array}$ & \\
\hline August & $\begin{array}{c}-0.011 * * * \\
(0.003)\end{array}$ & $\begin{array}{c}0.022 \\
(0.026)\end{array}$ & & $\begin{array}{c}-0.040^{* * *} \\
(0.004)\end{array}$ & $\begin{array}{l}-0.044 \\
(0.033)\end{array}$ & \\
\hline September & $\begin{array}{c}-0.014^{* * *} \\
(0.003)\end{array}$ & $\begin{array}{c}0.022 \\
(0.030)\end{array}$ & & $\begin{array}{c}-0.046^{* * *} \\
(0.004)\end{array}$ & $\begin{array}{l}-0.060 \\
(0.038)\end{array}$ & \\
\hline October & $\begin{array}{c}-0.015^{* * *} \\
(0.003)\end{array}$ & $\begin{array}{c}0.028 \\
(0.033)\end{array}$ & & $\begin{array}{c}-0.050^{* * *} \\
(0.004)\end{array}$ & $\begin{array}{l}-0.059 \\
(0.043)\end{array}$ & \\
\hline November & $\begin{array}{c}-0.017^{* * *} \\
(0.003)\end{array}$ & $\begin{array}{c}0.032 \\
(0.037)\end{array}$ & & $\begin{array}{c}-0.052^{* * *} \\
(0.005)\end{array}$ & $\begin{array}{l}-0.057 \\
(0.047)\end{array}$ & \\
\hline December & $\begin{array}{c}-0.018^{* * *} \\
(0.004)\end{array}$ & $\begin{array}{c}0.031 \\
(0.041)\end{array}$ & & $\begin{array}{c}-0.060^{* * *} \\
(0.005)\end{array}$ & $\begin{array}{l}-0.066 \\
(0.052)\end{array}$ & \\
\hline Female & $\begin{array}{c}-0.013^{* * *} \\
(0.001)\end{array}$ & $\begin{array}{c}-0.013^{* * *} \\
(0.002)\end{array}$ & $\begin{array}{c}-0.037 * * * \\
(0.009)\end{array}$ & $\begin{array}{c}-0.009 * * * \\
(0.001)\end{array}$ & $\begin{array}{c}-0.012 * * * \\
(0.002)\end{array}$ & $\begin{array}{l}-0.010 \\
(0.008)\end{array}$ \\
\hline \multicolumn{7}{|l|}{ Place of Birth: Own Home } \\
\hline Other Home & $\begin{array}{c}0.001 \\
(0.005)\end{array}$ & $\begin{array}{l}0.020^{*} \\
(0.011)\end{array}$ & & $\begin{array}{c}0.017^{* * *} \\
(0.006)\end{array}$ & $\begin{array}{c}0.013 \\
(0.012)\end{array}$ & \\
\hline Government Hospital & $\begin{array}{l}-0.003 \\
(0.002)\end{array}$ & $\begin{array}{l}0.009^{*} \\
(0.005)\end{array}$ & & $\begin{array}{c}-0.010 * * * \\
(0.003)\end{array}$ & $\begin{array}{l}-0.003 \\
(0.006)\end{array}$ & \\
\hline Government Clinic & $\begin{array}{c}0.000 \\
(0.002)\end{array}$ & $\begin{array}{c}0.002 \\
(0.006)\end{array}$ & & $\begin{array}{c}-0.015^{* * *} \\
(0.003)\end{array}$ & $\begin{array}{c}0.005 \\
(0.007)\end{array}$ & \\
\hline Private Hospital or Clinic & $\begin{array}{l}-0.003 \\
(0.002)\end{array}$ & $\begin{array}{c}0.006 \\
(0.006)\end{array}$ & & $\begin{array}{c}-0.012 * * * \\
(0.003)\end{array}$ & $\begin{array}{c}0.003 \\
(0.007)\end{array}$ & \\
\hline Other & $\begin{array}{l}-0.003 \\
(0.005)\end{array}$ & $\begin{array}{c}0.000 \\
(0.014)\end{array}$ & & $\begin{array}{l}-0.002 \\
(0.008)\end{array}$ & $\begin{array}{c}0.025 \\
(0.017)\end{array}$ & \\
\hline Missing & $\begin{array}{c}0.001 \\
(0.005)\end{array}$ & $\begin{array}{c}0.013 \\
(0.018)\end{array}$ & & $\begin{array}{l}-0.011 \\
(0.010)\end{array}$ & $\begin{array}{c}0.035 \\
(0.024)\end{array}$ & \\
\hline \multicolumn{7}{|l|}{ Birth Interval: 1st } \\
\hline 1-11 Months & $\begin{array}{c}0.002 \\
(0.006)\end{array}$ & $\begin{array}{l}-0.013 \\
(0.008)\end{array}$ & & $\begin{array}{l}-0.002 \\
(0.009)\end{array}$ & $\begin{array}{l}-0.006 \\
(0.010)\end{array}$ & \\
\hline 12-17 Months & $\begin{array}{c}-0.004 * \\
(0.003)\end{array}$ & $\begin{array}{c}-0.016 * * * \\
(0.004)\end{array}$ & & $\begin{array}{c}-0.017^{* * *} \\
(0.004)\end{array}$ & $\begin{array}{c}-0.021 * * * \\
(0.005)\end{array}$ & \\
\hline 18-23 Months & $\begin{array}{l}-0.000 \\
(0.002)\end{array}$ & $\begin{array}{c}-0.012^{* * *} \\
(0.003)\end{array}$ & & $\begin{array}{c}-0.019 * * * \\
(0.003)\end{array}$ & $\begin{array}{c}-0.017^{* * *} \\
(0.004)\end{array}$ & \\
\hline $24+$ Months & $\begin{array}{c}-0.005^{* *} * \\
(0.002)\end{array}$ & $\begin{array}{c}-0.006^{* *} \\
(0.003)\end{array}$ & & $\begin{array}{c}-0.009 * * * \\
(0.003)\end{array}$ & $\begin{array}{c}-0.008 * * \\
(0.003)\end{array}$ & \\
\hline Birth History: 1st & & & & & & \\
\hline 2 & $0.007 * * *$ & & & -0.005 & & \\
\hline
\end{tabular}




\begin{tabular}{|c|c|c|c|c|c|c|}
\hline \multirow[b]{2}{*}{ Variables } & \multicolumn{3}{|c|}{ Wasting } & \multicolumn{3}{|c|}{ Coughing } \\
\hline & OLS Full Sample & Sibling IV FE & IV FE Twins & OLS Full Sample & Sibling IV FE & IV FE Twins \\
\hline & $(0.002)$ & & & $(0.003)$ & & \\
\hline 3 & $\begin{array}{c}0.010 * * * \\
(0.003)\end{array}$ & $\begin{array}{l}-0.360 \\
(0.374)\end{array}$ & & $\begin{array}{l}-0.004 \\
(0.004)\end{array}$ & $\begin{array}{c}0.385 \\
(0.538)\end{array}$ & \\
\hline 4 & $\begin{array}{c}0.013 * * * \\
(0.003)\end{array}$ & $\begin{array}{c}0.116 \\
(0.356)\end{array}$ & & $\begin{array}{c}-0.008^{*} \\
(0.004)\end{array}$ & $\begin{array}{c}0.596 \\
(0.545)\end{array}$ & \\
\hline 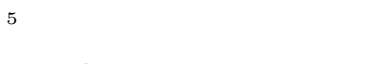 & $\begin{array}{c}0.012 * * * \\
(0.003)\end{array}$ & $\begin{array}{c}0.320 \\
(0.302)\end{array}$ & & $\begin{array}{l}-0.007 \\
(0.005)\end{array}$ & $\begin{array}{l}0.131 \\
(0.425)\end{array}$ & \\
\hline Birth Order: 1st & & & & & & \\
\hline 2 & $\begin{array}{c}-0.004^{* *} \\
(0.002)\end{array}$ & $\begin{array}{c}-0.036^{* * *} \\
(0.006)\end{array}$ & & $\begin{array}{c}-0.059^{* * *} \\
(0.003)\end{array}$ & $\begin{array}{c}-0.067^{* * *} \\
(0.007)\end{array}$ & \\
\hline 3 & $\begin{array}{l}-0.001 \\
(0.003)\end{array}$ & $\begin{array}{c}-0.053^{* * *} * \\
(0.009)\end{array}$ & & $\begin{array}{c}-0.103^{* * *} \\
(0.005)\end{array}$ & $\begin{array}{c}-0.122^{* * * *} \\
(0.011)\end{array}$ & \\
\hline 4 & $\begin{array}{l}-0.001 \\
(0.008)\end{array}$ & $\begin{array}{c}-0.069^{* * *} \\
(0.016)\end{array}$ & & $\begin{array}{c}-0.125^{* * *} \\
(0.014)\end{array}$ & $\begin{array}{c}-0.161 * * * \\
(0.020)\end{array}$ & \\
\hline 5 & $\begin{array}{c}0.001 \\
(0.035)\end{array}$ & $\begin{array}{c}-0.134^{* *} \\
(0.053)\end{array}$ & & $\begin{array}{c}-0.157^{* *} \\
(0.064)\end{array}$ & $\begin{array}{c}-0.142^{*} \\
(0.077)\end{array}$ & \\
\hline Mother's Age: 15-19 & & & & & & \\
\hline $20-24$ & $\begin{array}{c}-0.005^{*} \\
(0.002)\end{array}$ & & & $\begin{array}{c}-0.012^{* * *} \\
(0.003)\end{array}$ & & \\
\hline $25-29$ & $\begin{array}{c}-0.006^{* *} \\
(0.003)\end{array}$ & & & $\begin{array}{c}-0.018 * * * \\
(0.004)\end{array}$ & & \\
\hline $30-34$ & $\begin{array}{c}-0.006^{* *} \\
(0.003)\end{array}$ & & & $\begin{array}{c}-0.024 * * * \\
(0.004)\end{array}$ & & \\
\hline 35-39 & $\begin{array}{l}-0.004 \\
(0.003)\end{array}$ & & & $\begin{array}{c}-0.035^{* * *} \\
(0.004)\end{array}$ & & \\
\hline $40-44$ & $\begin{array}{l}-0.005 \\
(0.003)\end{array}$ & & & $\begin{array}{c}-0.042^{* * *} \\
(0.005)\end{array}$ & & \\
\hline $45-49$ & $\begin{array}{l}-0.007 \\
(0.005)\end{array}$ & & & $\begin{array}{c}-0.052^{* * *} \\
(0.007)\end{array}$ & & \\
\hline Rural & $\begin{array}{c}-0.004^{* *} \\
(0.001)\end{array}$ & & & $\begin{array}{c}-0.004^{*} \\
(0.002)\end{array}$ & & \\
\hline Mother's Education: None & & & & & & \\
\hline Primary & $\begin{array}{c}-0.007 * * * \\
(0.002)\end{array}$ & & & $\begin{array}{c}0.016^{* * *} \\
(0.003)\end{array}$ & & \\
\hline Secondary & $\begin{array}{c}-0.012 * * * \\
(0.002)\end{array}$ & & & $\begin{array}{c}0.013^{* * *} \\
(0.003)\end{array}$ & & \\
\hline Tertiary & $\begin{array}{c}-0.016^{* * *} \\
(0.003)\end{array}$ & & & $\begin{array}{c}0.001 \\
(0.004)\end{array}$ & & \\
\hline Don't Know/Missing & $\begin{array}{l}-0.056 \\
(0.035)\end{array}$ & & & $\begin{array}{c}-0.005 \\
(0.053)\end{array}$ & & \\
\hline Toilet in House: No & & & & & & \\
\hline Yes & $\begin{array}{c}-0.005 * * * \\
(0.002)\end{array}$ & & & $\begin{array}{l}-0.003 \\
(0.003)\end{array}$ & & \\
\hline Missing & $\begin{array}{c}0.019^{* * *} \\
(0.005)\end{array}$ & & & $\begin{array}{c}-0.025 * * * \\
(0.008)\end{array}$ & & \\
\hline Water in House: No & & & & & & \\
\hline Yes & $\begin{array}{c}0.000 \\
(0.001)\end{array}$ & & & $\begin{array}{c}0.001 \\
(0.002)\end{array}$ & & \\
\hline Missing & $\begin{array}{c}-0.020 * * * \\
(0.006)\end{array}$ & & & $\begin{array}{c}0.018^{* *} \\
(0.009)\end{array}$ & & \\
\hline Partner's Education: None & & & & & & \\
\hline Primary & $\begin{array}{c}-0.008^{* * *} \\
(0.002)\end{array}$ & & & $\begin{array}{c}0.016 * * * \\
(0.003)\end{array}$ & & \\
\hline Secondary & $\begin{array}{c}-0.009^{* * *} \\
(0.002)\end{array}$ & & & $\begin{array}{c}0.016^{* * *} \\
(0.003)\end{array}$ & & \\
\hline Tertiary & $\begin{array}{c}-0.012^{* * * *} \\
(0.003)\end{array}$ & & & $\begin{array}{c}0.004 \\
(0.004)\end{array}$ & & \\
\hline Don't Know/Missing & $\begin{array}{c}-0.012 * * * \\
(0.003)\end{array}$ & & & $\begin{array}{c}0.017^{* * *} \\
(0.005)\end{array}$ & & \\
\hline Marital Status: Never Married & & & & & & \\
\hline Married & $\begin{array}{c}-0.009 * * * \\
(0.003)\end{array}$ & & & $\begin{array}{c}0.032^{* * *} \\
(0.006)\end{array}$ & & \\
\hline Living Together & $\begin{array}{c}-0.007^{* *} \\
(0.003)\end{array}$ & & & $\begin{array}{c}0.048^{* * *} \\
(0.006)\end{array}$ & & \\
\hline Widowed & $\begin{array}{l}-0.002 \\
(0.006)\end{array}$ & & & $\begin{array}{c}0.020 * * \\
(0.009)\end{array}$ & & \\
\hline Divorced & $\begin{array}{l}-0.005 \\
(0.005)\end{array}$ & & & $\begin{array}{c}0.035^{* * *} \\
(0.008)\end{array}$ & & \\
\hline Not Living Together & $\begin{array}{l}-0.004 \\
(0.004)\end{array}$ & & & $\begin{array}{c}0.051^{* * *} \\
(0.007)\end{array}$ & & \\
\hline Religion: Christian & & & & & & \\
\hline Muslim & $\begin{array}{c}0.011 * * * \\
(0.002)\end{array}$ & & & $\begin{array}{c}-0.015 * * * \\
(0.003)\end{array}$ & & \\
\hline Jewish & $\begin{array}{l}-0.003 \\
(0.006)\end{array}$ & & & $\begin{array}{c}0.040^{* *} \\
(0.016)\end{array}$ & & \\
\hline Buddhist & $\begin{array}{l}-0.023 \\
(0.015)\end{array}$ & & & $\begin{array}{c}-0.028^{* *} \\
(0.013)\end{array}$ & & \\
\hline
\end{tabular}




\begin{tabular}{|c|c|c|c|c|c|c|}
\hline \multirow[b]{2}{*}{ Variables } & \multicolumn{3}{|c|}{ Wasting } & \multicolumn{3}{|c|}{ Coughing } \\
\hline & OLS Full Sample & Sibling IV FE & IV FE Twins & OLS Full Sample & Sibling IV FE & IV FE Twins \\
\hline Hindu & $\begin{array}{c}0.021^{* * *} \\
(0.006)\end{array}$ & & & $\begin{array}{l}-0.040 * * * \\
(0.006)\end{array}$ & & \\
\hline Sikh & $\begin{array}{c}-0.074 * * * \\
(0.010)\end{array}$ & & & $\begin{array}{l}-0.030 \\
(0.022)\end{array}$ & & \\
\hline Traditional & $\begin{array}{l}-0.001 \\
(0.006)\end{array}$ & & & $\begin{array}{c}0.020 * * \\
(0.008)\end{array}$ & & \\
\hline Other & $\begin{array}{c}0.000 \\
(0.004)\end{array}$ & & & $\begin{array}{c}0.018^{* * *} \\
(0.007)\end{array}$ & & \\
\hline None & $\begin{array}{c}0.003 \\
(0.003)\end{array}$ & & & $\begin{array}{c}0.005 \\
(0.006)\end{array}$ & & \\
\hline Unknown & $\begin{array}{c}0.002 \\
(0.004)\end{array}$ & & & $\begin{array}{l}-0.060 * * * \\
(0.007)\end{array}$ & & \\
\hline $\begin{array}{l}\text { Maternal Tetanus Injection: Yes } \\
\text { None }\end{array}$ & $\begin{array}{c}0.000 \\
(0.001)\end{array}$ & $\begin{array}{l}0.006^{*} \\
(0.003)\end{array}$ & & $\begin{array}{c}-0.005^{* *} \\
(0.002)\end{array}$ & $\begin{array}{c}-0.009 * * \\
(0.004)\end{array}$ & \\
\hline Missing & $\begin{array}{l}-0.000 \\
(0.003)\end{array}$ & $\begin{array}{l}0.009 \\
(0.007)\end{array}$ & & $\begin{array}{c}0.005 \\
(0.004)\end{array}$ & $\begin{array}{l}-0.013 \\
(0.009)\end{array}$ & \\
\hline Wanted Birth: Before & & & & & & \\
\hline Later & $\begin{array}{l}-0.003 * * * \\
(0.001)\end{array}$ & $\begin{array}{l}-0.003 \\
(0.003)\end{array}$ & & $\begin{array}{c}0.048^{* * *} \\
(0.002)\end{array}$ & $\begin{array}{c}0.000 \\
(0.003)\end{array}$ & \\
\hline No More & $\begin{array}{c}-0.003^{* *} \\
(0.001)\end{array}$ & $\begin{array}{c}0.002 \\
(0.004)\end{array}$ & & $\begin{array}{c}0.041^{* * *} \\
(0.002)\end{array}$ & $\begin{array}{l}0.010^{* *} \\
(0.005)\end{array}$ & \\
\hline Don't Know/Missing & $\begin{array}{c}0.013 \\
(0.015)\end{array}$ & $\begin{array}{l}-0.026 \\
(0.033)\end{array}$ & & $\begin{array}{c}0.015 \\
(0.024)\end{array}$ & $\begin{array}{c}0.025 \\
(0.040)\end{array}$ & \\
\hline Antenatal Visit: No & & & & & & \\
\hline Yes & $\begin{array}{l}-0.007 * * * \\
(0.002)\end{array}$ & $\begin{array}{l}-0.005 \\
(0.006)\end{array}$ & & $\begin{array}{c}0.009 * * \\
(0.004)\end{array}$ & $\begin{array}{c}0.009 \\
(0.008)\end{array}$ & \\
\hline Missing & $\begin{array}{l}-0.012 * * * \\
(0.003)\end{array}$ & $\begin{array}{l}-0.010 \\
(0.009)\end{array}$ & & $\begin{array}{c}0.004 \\
(0.006)\end{array}$ & $\begin{array}{c}0.004 \\
(0.011)\end{array}$ & \\
\hline Constant & $\begin{array}{c}0.630 \\
(2.876)\end{array}$ & $\begin{array}{l}-6.527 \\
(6.562)\end{array}$ & $\begin{array}{l}0.325^{*} \\
(0.194)\end{array}$ & $\begin{array}{c}-22.197^{* * *} \\
(4.792)\end{array}$ & $\begin{array}{l}-2.312 \\
(8.643)\end{array}$ & $\begin{array}{c}0.579^{* * *} * \\
(0.164)\end{array}$ \\
\hline Observations & 333,815 & 158,639 & 7,262 & 486,745 & 226,559 & 10,367 \\
\hline
\end{tabular}

Note: Birth weight coefficients are multipled by 1000. Models using observations with birth weight data are shown. Where they are not part of the fixed effect, the models include controls for year of birth fixed effects, survey year fixed effects, country specific year of birth trends, country specific wealth index quintile and country fixed effects, which are not shown in the table. Standard errors in the OLS model are adjusted for clustering at the household level. 
Table A15 Effects of Birth Weight on Fever and Diarrhoea- Full Table

\begin{tabular}{|c|c|c|c|c|c|c|}
\hline \multirow[b]{2}{*}{ Variables } & \multicolumn{3}{|c|}{ Fever } & \multicolumn{3}{|c|}{ Diarrhoea } \\
\hline & OLS Full Sample & Sibling IV FE & IV FE Twins & OLS Full Sample & Sibling IV FE & IV FE Twins \\
\hline Birth Weight & $\begin{array}{c}-0.099 * * * \\
(0.007)\end{array}$ & $\begin{array}{c}-0.051^{*} \\
(0.028)\end{array}$ & $\begin{array}{l}-0.000 \\
(0.000)\end{array}$ & $\begin{array}{c}-0.064^{* * *} \\
(0.005)\end{array}$ & $\begin{array}{c}0.000 \\
(0.025)\end{array}$ & $\begin{array}{l}-0.000 \\
(0.000)\end{array}$ \\
\hline Birth Weight Squared & $\begin{array}{c}0.015^{* * *} \\
(0.001)\end{array}$ & $\begin{array}{c}0.007 \\
(0.004)\end{array}$ & $\begin{array}{c}0.000 \\
(0.000)\end{array}$ & $\begin{array}{c}0.010^{* * *} \\
(0.001)\end{array}$ & $\begin{array}{l}-0.000 \\
(0.004)\end{array}$ & $\begin{array}{c}0.000 \\
(0.000)\end{array}$ \\
\hline \multicolumn{7}{|l|}{ Wealth Index: Lowest } \\
\hline Lower & $\begin{array}{c}0.016 \\
(0.017)\end{array}$ & & & $\begin{array}{l}-0.006 \\
(0.011)\end{array}$ & & \\
\hline Middle & $\begin{array}{l}-0.007 \\
(0.016)\end{array}$ & & & $\begin{array}{c}-0.020^{*} \\
(0.011)\end{array}$ & & \\
\hline Rich & $\begin{array}{l}-0.013 \\
(0.017)\end{array}$ & & & $\begin{array}{c}-0.020^{*} \\
(0.011)\end{array}$ & & \\
\hline Richest & $\begin{array}{c}-0.096 * * * \\
(0.017)\end{array}$ & & & $\begin{array}{c}-0.043^{* * *} \\
(0.011)\end{array}$ & & \\
\hline Months Since Birth & $\begin{array}{c}-0.004^{* * *} \\
(0.000)\end{array}$ & $\begin{array}{c}-0.016^{* * *} \\
(0.005)\end{array}$ & & $\begin{array}{c}-0.004^{* * *} \\
(0.000)\end{array}$ & $\begin{array}{l}-0.000 \\
(0.004)\end{array}$ & \\
\hline \multicolumn{7}{|l|}{ Multiple Birth: Singleton } \\
\hline First of Multiple & $\begin{array}{c}0.045^{* * *} \\
(0.006)\end{array}$ & $\begin{array}{c}0.056 * * * \\
(0.010)\end{array}$ & & $\begin{array}{c}0.025 * * * \\
(0.005)\end{array}$ & $\begin{array}{c}0.047^{* * *} \\
(0.009)\end{array}$ & \\
\hline Second of Multiple & $\begin{array}{l}-0.003 \\
(0.006)\end{array}$ & $\begin{array}{l}-0.014 \\
(0.010)\end{array}$ & $\begin{array}{c}0.017^{* * *} \\
(0.005)\end{array}$ & $\begin{array}{l}-0.005 \\
(0.005)\end{array}$ & $\begin{array}{l}-0.013 \\
(0.009)\end{array}$ & $\begin{array}{c}0.006 \\
(0.004)\end{array}$ \\
\hline Third of Multiple & $\begin{array}{l}-0.044 \\
(0.048)\end{array}$ & $\begin{array}{c}-0.092 * \\
(0.051)\end{array}$ & & $\begin{array}{l}-0.034 \\
(0.036)\end{array}$ & $\begin{array}{l}-0.053 \\
(0.045)\end{array}$ & \\
\hline Fourth of Multiple & $\begin{array}{c}0.797 * * * \\
(0.009)\end{array}$ & $\begin{array}{l}-0.170 \\
(0.372)\end{array}$ & & $\begin{array}{c}-0.257 * * * \\
(0.008)\end{array}$ & $\begin{array}{l}-0.440 \\
(0.332)\end{array}$ & \\
\hline \multicolumn{7}{|l|}{ Month of Birth: January } \\
\hline February & $\begin{array}{c}-0.012 * * * \\
(0.003)\end{array}$ & $\begin{array}{c}-0.016^{* *} \\
(0.007)\end{array}$ & & $\begin{array}{c}-0.007 * * * \\
(0.003)\end{array}$ & $\begin{array}{c}0.008 \\
(0.006)\end{array}$ & \\
\hline March & $\begin{array}{c}-0.007^{* *} \\
(0.003)\end{array}$ & $\begin{array}{c}-0.033^{* * *} \\
(0.011)\end{array}$ & & $\begin{array}{c}-0.008 * * * \\
(0.003)\end{array}$ & $\begin{array}{c}0.001 \\
(0.010)\end{array}$ & \\
\hline April & $\begin{array}{c}-0.015^{* * *} \\
(0.003)\end{array}$ & $\begin{array}{c}-0.051 * * * \\
(0.015)\end{array}$ & & $\begin{array}{c}-0.011 * * * \\
(0.003)\end{array}$ & $\begin{array}{c}0.000 \\
(0.014)\end{array}$ & \\
\hline May & $\begin{array}{c}-0.021 * * * \\
(0.003)\end{array}$ & $\begin{array}{c}-0.069 * * * \\
(0.020)\end{array}$ & & $\begin{array}{c}-0.015^{* * *} * \\
(0.003)\end{array}$ & $\begin{array}{l}-0.003 \\
(0.018)\end{array}$ & \\
\hline June & $\begin{array}{c}-0.025 * * * \\
(0.004)\end{array}$ & $\begin{array}{c}-0.084^{* * * *} \\
(0.024)\end{array}$ & & $\begin{array}{c}-0.017 * * * \\
(0.003)\end{array}$ & $\begin{array}{l}-0.002 \\
(0.022)\end{array}$ & \\
\hline July & $\begin{array}{c}-0.032^{* * *} \\
(0.004)\end{array}$ & $\begin{array}{c}-0.109^{* * *} \\
(0.029)\end{array}$ & & $\begin{array}{c}-0.022 * * * \\
(0.003)\end{array}$ & $\begin{array}{c}0.000 \\
(0.026)\end{array}$ & \\
\hline August & $\begin{array}{c}-0.032 * * * \\
(0.004)\end{array}$ & $\begin{array}{c}-0.121^{* * *} \\
(0.034)\end{array}$ & & $\begin{array}{c}-0.023^{* * *} * \\
(0.003)\end{array}$ & $\begin{array}{l}-0.003 \\
(0.030)\end{array}$ & \\
\hline September & $\begin{array}{c}-0.031 * * * \\
(0.004)\end{array}$ & $\begin{array}{c}-0.144^{* * *} \\
(0.039)\end{array}$ & & $\begin{array}{c}-0.023 * * * \\
(0.003)\end{array}$ & $\begin{array}{c}0.007 \\
(0.035)\end{array}$ & \\
\hline October & $\begin{array}{c}-0.035 * * * \\
(0.004)\end{array}$ & $\begin{array}{c}-0.147^{* * *} * \\
(0.043)\end{array}$ & & $\begin{array}{c}-0.023^{* * *} * \\
(0.003)\end{array}$ & $\begin{array}{c}0.009 \\
(0.039)\end{array}$ & \\
\hline November & $\begin{array}{c}-0.037^{* * *} \\
(0.004)\end{array}$ & $\begin{array}{c}-0.164^{* * *} \\
(0.048)\end{array}$ & & $\begin{array}{c}-0.022 * * * \\
(0.003)\end{array}$ & $\begin{array}{c}0.014 \\
(0.043)\end{array}$ & \\
\hline December & $\begin{array}{c}-0.037 * * * \\
(0.005)\end{array}$ & $\begin{array}{c}-0.178 * * * \\
(0.053)\end{array}$ & & $\begin{array}{c}-0.027^{* * *} \\
(0.004)\end{array}$ & $\begin{array}{c}0.013 \\
(0.047)\end{array}$ & \\
\hline Female & $\begin{array}{c}-0.010 * * * \\
(0.001)\end{array}$ & $\begin{array}{c}-0.015 * * * \\
(0.002)\end{array}$ & $\begin{array}{l}-0.013 \\
(0.008)\end{array}$ & $\begin{array}{c}-0.011 * * * \\
(0.001)\end{array}$ & $\begin{array}{c}-0.013 * * * \\
(0.002)\end{array}$ & $\begin{array}{c}-0.012^{*} \\
(0.007)\end{array}$ \\
\hline \multicolumn{7}{|l|}{ Place of Birth: Own Home } \\
\hline Other Home & $\begin{array}{c}0.012 * * \\
(0.005)\end{array}$ & $\begin{array}{c}0.016 \\
(0.012)\end{array}$ & & $\begin{array}{c}-0.009^{* *} \\
(0.004)\end{array}$ & $\begin{array}{l}-0.014 \\
(0.011)\end{array}$ & \\
\hline Government Hospital & $\begin{array}{c}-0.011 * * * \\
(0.003)\end{array}$ & $\begin{array}{c}0.006 \\
(0.006)\end{array}$ & & $\begin{array}{c}-0.015^{* * *} \\
(0.002)\end{array}$ & $\begin{array}{l}-0.001 \\
(0.005)\end{array}$ & \\
\hline Government Clinic & $\begin{array}{c}-0.008 * * * \\
(0.003)\end{array}$ & $\begin{array}{c}0.007 \\
(0.007)\end{array}$ & & $\begin{array}{c}-0.011 * * * \\
(0.002)\end{array}$ & $\begin{array}{c}0.002 \\
(0.006)\end{array}$ & \\
\hline Private Hospital or Clinic & $\begin{array}{c}-0.017 * * * \\
(0.003)\end{array}$ & $\begin{array}{c}0.011 \\
(0.007)\end{array}$ & & $\begin{array}{c}-0.021 * * * \\
(0.002)\end{array}$ & $\begin{array}{l}-0.007 \\
(0.006)\end{array}$ & \\
\hline Other & $\begin{array}{l}-0.004 \\
(0.008)\end{array}$ & $\begin{array}{c}0.019 \\
(0.017)\end{array}$ & & $\begin{array}{l}-0.009 \\
(0.007)\end{array}$ & $\begin{array}{l}-0.004 \\
(0.015)\end{array}$ & \\
\hline Missing & $\begin{array}{c}-0.018^{*} \\
(0.010)\end{array}$ & $\begin{array}{c}0.027 \\
(0.025)\end{array}$ & & $\begin{array}{c}-0.032^{* * *} \\
(0.007)\end{array}$ & $\begin{array}{l}-0.025 \\
(0.022)\end{array}$ & \\
\hline \multicolumn{7}{|l|}{ Birth Interval: 1st } \\
\hline 1-11 Months & $\begin{array}{c}-0.014^{*} \\
(0.008)\end{array}$ & $\begin{array}{c}-0.020^{*} \\
(0.010)\end{array}$ & & $\begin{array}{l}-0.000 \\
(0.007)\end{array}$ & $\begin{array}{l}-0.008 \\
(0.009)\end{array}$ & \\
\hline 12-17 Months & $\begin{array}{c}-0.026^{* * *} \\
(0.004)\end{array}$ & $\begin{array}{c}-0.024^{* * *} \\
(0.005)\end{array}$ & & $\begin{array}{l}-0.000 \\
(0.003)\end{array}$ & $\begin{array}{c}-0.010^{* *} \\
(0.004)\end{array}$ & \\
\hline 18-23 Months & $\begin{array}{c}-0.023^{* * * *} \\
(0.003)\end{array}$ & $\begin{array}{c}-0.015^{* * * *} \\
(0.004)\end{array}$ & & $\begin{array}{l}-0.001 \\
(0.003)\end{array}$ & $\begin{array}{l}-0.005 \\
(0.004)\end{array}$ & \\
\hline $24+$ Months & $\begin{array}{c}-0.014^{* * *} \\
(0.003)\end{array}$ & $\begin{array}{c}-0.007^{* *} \\
(0.003)\end{array}$ & & $\begin{array}{l}-0.001 \\
(0.002)\end{array}$ & $\begin{array}{l}-0.001 \\
(0.003)\end{array}$ & \\
\hline Birth History: 1st & & & & & & \\
\hline 2 & 0.004 & & & $-0.004^{*}$ & & \\
\hline
\end{tabular}




\begin{tabular}{|c|c|c|c|c|c|c|}
\hline \multirow[b]{2}{*}{ Variables } & \multicolumn{3}{|c|}{ Fever } & \multicolumn{3}{|c|}{ Diarrhoea } \\
\hline & OLS Full Sample & Sibling IV FE & IV FE Twins & OLS Full Sample & Sibling IV FE & IV FE Twins \\
\hline & $(0.003)$ & & & $(0.002)$ & & \\
\hline 3 & $\begin{array}{c}0.013 * * * \\
(0.004)\end{array}$ & $\begin{array}{l}0.994^{*} \\
(0.549)\end{array}$ & & $\begin{array}{l}-0.003 \\
(0.003)\end{array}$ & $\begin{array}{l}-0.019 \\
(0.490)\end{array}$ & \\
\hline 4 & $\begin{array}{c}0.015 * * * \\
(0.004)\end{array}$ & $\begin{array}{c}0.623 \\
(0.557)\end{array}$ & & $\begin{array}{l}-0.001 \\
(0.003)\end{array}$ & $\begin{array}{c}0.592 \\
(0.497)\end{array}$ & \\
\hline 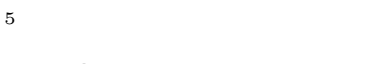 & $\begin{array}{c}0.024^{* * *} \\
(0.004)\end{array}$ & $\begin{array}{c}-0.464 \\
(0.434)\end{array}$ & & $\begin{array}{c}0.001 \\
(0.004)\end{array}$ & $\begin{array}{c}0.514 \\
(0.387)\end{array}$ & \\
\hline Birth Order: 1st & & & & & & \\
\hline 2 & $\begin{array}{c}-0.069 * * * \\
(0.003)\end{array}$ & $\begin{array}{c}-0.074 * * * \\
(0.007)\end{array}$ & & $\begin{array}{c}-0.038 * * * \\
(0.002)\end{array}$ & $\begin{array}{c}-0.062 * * * \\
(0.006)\end{array}$ & \\
\hline 3 & $\begin{array}{c}-0.111^{* * *} \\
(0.005)\end{array}$ & $\begin{array}{c}-0.129^{* * *} \\
(0.011)\end{array}$ & & $\begin{array}{c}-0.053^{* * *} \\
(0.003)\end{array}$ & $\begin{array}{c}-0.092 * * * \\
(0.010)\end{array}$ & \\
\hline 4 & $\begin{array}{c}-0.143^{* * *} \\
(0.013)\end{array}$ & $\begin{array}{c}-0.185^{* * *} \\
(0.021)\end{array}$ & & $\begin{array}{c}-0.045^{* * *} \\
(0.009)\end{array}$ & $\begin{array}{c}-0.118^{* * *} \\
(0.018)\end{array}$ & \\
\hline 5 & $\begin{array}{c}-0.172^{* * *} \\
(0.050)\end{array}$ & $\begin{array}{c}-0.200 * * * \\
(0.076)\end{array}$ & & $\begin{array}{l}-0.001 \\
(0.053)\end{array}$ & $\begin{array}{c}-0.136^{* *} \\
(0.068)\end{array}$ & \\
\hline Mother's Age: 15-19 & & & & & & \\
\hline $20-24$ & $\begin{array}{c}0.000 \\
(0.003)\end{array}$ & & & $\begin{array}{c}-0.020 * * * \\
(0.003)\end{array}$ & & \\
\hline $25-29$ & $\begin{array}{c}-0.006^{*} \\
(0.003)\end{array}$ & & & $\begin{array}{c}-0.034 * * * \\
(0.003)\end{array}$ & & \\
\hline $30-34$ & $\begin{array}{c}-0.010 * * \\
(0.004)\end{array}$ & & & $\begin{array}{c}-0.044^{* * *} \\
(0.003)\end{array}$ & & \\
\hline $35-39$ & $\begin{array}{c}-0.016^{* * *} \\
(0.004)\end{array}$ & & & $\begin{array}{c}-0.055^{* * *} \\
(0.004)\end{array}$ & & \\
\hline $40-44$ & $\begin{array}{c}-0.026^{* * *} \\
(0.005)\end{array}$ & & & $\begin{array}{c}-0.056^{* * *} \\
(0.004)\end{array}$ & & \\
\hline $45-49$ & $\begin{array}{c}-0.035^{* * *} * \\
(0.007)\end{array}$ & & & $\begin{array}{c}-0.068 * * * \\
(0.006)\end{array}$ & & \\
\hline Rural & $\begin{array}{c}0.005 * * * \\
(0.002)\end{array}$ & & & $\begin{array}{c}-0.007 * * * \\
(0.002)\end{array}$ & & \\
\hline Mother's Education: None & & & & & & \\
\hline Primary & $\begin{array}{c}0.009 * * * \\
(0.002)\end{array}$ & & & $\begin{array}{l}-0.000 \\
(0.002)\end{array}$ & & \\
\hline Secondary & $\begin{array}{l}-0.002 \\
(0.003)\end{array}$ & & & $\begin{array}{c}-0.014^{* * *} \\
(0.002)\end{array}$ & & \\
\hline Tertiary & $\begin{array}{c}-0.016^{* * *} \\
(0.004)\end{array}$ & & & $\begin{array}{c}-0.028 * * * \\
(0.003)\end{array}$ & & \\
\hline Don't Know/Missing & $\begin{array}{l}-0.007 \\
(0.051)\end{array}$ & & & $\begin{array}{c}-0.046 * * \\
(0.023)\end{array}$ & & \\
\hline Toilet in House: No & & & & & & \\
\hline Yes & $\begin{array}{l}-0.002 \\
(0.002)\end{array}$ & & & $\begin{array}{c}-0.005 * * * \\
(0.002)\end{array}$ & & \\
\hline Missing & $\begin{array}{c}-0.016^{*} \\
(0.009)\end{array}$ & & & $\begin{array}{c}-0.017 * * * \\
(0.006)\end{array}$ & & \\
\hline Water in House: No & & & & & & \\
\hline Yes & $\begin{array}{c}-0.008 * * * \\
(0.002)\end{array}$ & & & $\begin{array}{c}0.001 \\
(0.001)\end{array}$ & & \\
\hline Missing & $\begin{array}{c}0.007 \\
(0.009)\end{array}$ & & & $\begin{array}{c}0.016 * * \\
(0.007)\end{array}$ & & \\
\hline Partner's Education: None & & & & & & \\
\hline Primary & $\begin{array}{c}0.011 * * * \\
(0.003)\end{array}$ & & & $\begin{array}{l}0.004^{*} \\
(0.002)\end{array}$ & & \\
\hline Secondary & $\begin{array}{c}0.008 * * * \\
(0.003)\end{array}$ & & & $\begin{array}{l}-0.001 \\
(0.002)\end{array}$ & & \\
\hline Tertiary & $\begin{array}{c}0.001 \\
(0.004)\end{array}$ & & & $\begin{array}{c}-0.008 * * * \\
(0.003)\end{array}$ & & \\
\hline Don't Know/Missing & $\begin{array}{l}0.009^{*} \\
(0.005)\end{array}$ & & & $\begin{array}{c}0.010 * * * \\
(0.004)\end{array}$ & & \\
\hline Marital Status: Never Married & & & & & & \\
\hline Married & $\begin{array}{c}0.025 * * * \\
(0.006)\end{array}$ & & & $\begin{array}{c}0.027 * * * \\
(0.005)\end{array}$ & & \\
\hline Living Together & $\begin{array}{c}0.036 * * * \\
(0.006)\end{array}$ & & & $\begin{array}{c}0.039 * * * \\
(0.005)\end{array}$ & & \\
\hline Widowed & $\begin{array}{c}0.037 * * * \\
(0.009)\end{array}$ & & & $\begin{array}{c}0.035 * * * \\
(0.007)\end{array}$ & & \\
\hline Divorced & $\begin{array}{c}0.033^{* * *} \\
(0.008)\end{array}$ & & & $\begin{array}{c}0.046 * * * \\
(0.006)\end{array}$ & & \\
\hline Not Living Together & $\begin{array}{c}0.047 * * * \\
(0.006)\end{array}$ & & & $\begin{array}{c}0.042 * * * \\
(0.005)\end{array}$ & & \\
\hline Religion: Christian & & & & & & \\
\hline Muslim & $\begin{array}{l}-0.001 \\
(0.003)\end{array}$ & & & $\begin{array}{c}0.004 \\
(0.002)\end{array}$ & & \\
\hline Jewish & $\begin{array}{c}0.025 \\
(0.015)\end{array}$ & & & $\begin{array}{c}0.000 \\
(0.012)\end{array}$ & & \\
\hline Buddhist & $\begin{array}{c}-0.026^{*} \\
(0.014)\end{array}$ & & & $\begin{array}{l}-0.005 \\
(0.010)\end{array}$ & & \\
\hline
\end{tabular}




\begin{tabular}{|c|c|c|c|c|c|c|}
\hline \multirow[b]{2}{*}{ Variables } & \multicolumn{3}{|c|}{ Fever } & \multicolumn{3}{|c|}{ Diarrhoea } \\
\hline & OLS Full Sample & Sibling IV FE & IV FE Twins & OLS Full Sample & Sibling IV FE & IV FE Twins \\
\hline Hindu & $\begin{array}{c}-0.049^{* * *} \\
(0.006)\end{array}$ & & & $\begin{array}{c}-0.017^{* * *} \\
(0.005)\end{array}$ & & \\
\hline Sikh & $\begin{array}{l}-0.031 \\
(0.020)\end{array}$ & & & $\begin{array}{c}-0.005 \\
(0.016)\end{array}$ & & \\
\hline Traditional & $\begin{array}{c}0.022^{* *} \\
(0.009)\end{array}$ & & & $\begin{array}{c}0.007 \\
(0.006)\end{array}$ & & \\
\hline Other & $\begin{array}{l}-0.002 \\
(0.007)\end{array}$ & & & $\begin{array}{c}0.011 * * \\
(0.005)\end{array}$ & & \\
\hline None & $\begin{array}{c}0.002 \\
(0.005)\end{array}$ & & & $\begin{array}{c}-0.002 \\
(0.004)\end{array}$ & & \\
\hline Unknown & $\begin{array}{c}-0.039 * * * \\
(0.006)\end{array}$ & & & $\begin{array}{l}-0.003 \\
(0.005)\end{array}$ & & \\
\hline Maternal Tetanus Injection: Yes & & & & & & \\
\hline None & $\begin{array}{c}-0.012 * * * \\
(0.002)\end{array}$ & $\begin{array}{c}-0.012 * * * \\
(0.004)\end{array}$ & & $\begin{array}{c}-0.004^{* *} \\
(0.002)\end{array}$ & $\begin{array}{c}-0.010 * * * \\
(0.003)\end{array}$ & \\
\hline Missing & $\begin{array}{c}-0.015^{* * *} \\
(0.004)\end{array}$ & $\begin{array}{c}-0.029^{* * *} \\
(0.009)\end{array}$ & & $\begin{array}{l}-0.004 \\
(0.003)\end{array}$ & $\begin{array}{l}-0.002 \\
(0.008)\end{array}$ & \\
\hline Wanted Birth: Before & & & & & & \\
\hline Later & $\begin{array}{c}0.037^{* * *} \\
(0.002)\end{array}$ & $\begin{array}{c}0.001 \\
(0.003)\end{array}$ & & $\begin{array}{c}0.022 * * * \\
(0.001)\end{array}$ & $\begin{array}{c}0.001 \\
(0.003)\end{array}$ & \\
\hline No More & $\begin{array}{c}0.034^{* * *} \\
(0.002)\end{array}$ & $\begin{array}{c}0.007 \\
(0.005)\end{array}$ & & $\begin{array}{c}0.027^{* * *} * \\
(0.002)\end{array}$ & $\begin{array}{c}0.009 * * \\
(0.004)\end{array}$ & \\
\hline Don't Know/Missing & $\begin{array}{l}-0.013 \\
(0.024)\end{array}$ & $\begin{array}{l}-0.015 \\
(0.040)\end{array}$ & & $\begin{array}{l}-0.000 \\
(0.018)\end{array}$ & $\begin{array}{l}-0.019 \\
(0.035)\end{array}$ & \\
\hline Antenatal Visit: No & & & & & & \\
\hline Yes & $\begin{array}{c}0.005 \\
(0.004)\end{array}$ & $\begin{array}{c}0.001 \\
(0.008)\end{array}$ & & $\begin{array}{c}-0.013^{* * *} \\
(0.003)\end{array}$ & $\begin{array}{l}-0.007 \\
(0.007)\end{array}$ & \\
\hline Missing & $\begin{array}{c}0.006 \\
(0.006)\end{array}$ & $\begin{array}{l}-0.003 \\
(0.012)\end{array}$ & & $\begin{array}{c}-0.017 * * * \\
(0.004)\end{array}$ & $\begin{array}{c}-0.024^{* *} \\
(0.010)\end{array}$ & \\
\hline Constant & $\begin{array}{c}11.981 * * \\
(4.674)\end{array}$ & $\begin{array}{l}-2.225 \\
(8.796)\end{array}$ & $\begin{array}{c}0.533^{* * *} \\
(0.179)\end{array}$ & $\begin{array}{c}23.662 * * * \\
(3.509)\end{array}$ & $\begin{array}{l}-3.587 \\
(7.843)\end{array}$ & $\begin{array}{c}0.358^{* *} \\
(0.142)\end{array}$ \\
\hline Observations & 480,000 & 223,843 & 10,313 & 494,210 & 229,924 & 10,516 \\
\hline
\end{tabular}

Note: Birth weight coefficients are multiplied by 1000. Models using observations with birth weight data are shown. Where they are not part of the fixed effect, the models include controls for year of birth fixed effects, survey year fixed effects, country specific year of birth trends, country specific wealth index quintile and country fixed effects, which are not shown in the table. Standard errors in the OLS model are adjusted for clustering at the household level. 
Table A16 Effects of Birth Weight on Anaemia - Full Table

\begin{tabular}{|c|c|c|}
\hline \multirow[b]{2}{*}{ Variables } & \multicolumn{2}{|c|}{ Anaemia } \\
\hline & OLS Full Sample & Sibling IV FE \\
\hline Birth Weight & $\begin{array}{c}-0.076^{* * *} \\
(0.014)\end{array}$ & $\begin{array}{l}-0.120 \\
(0.078)\end{array}$ \\
\hline Birth Weight Squared & $\begin{array}{c}0.011 * * * \\
(0.002)\end{array}$ & $\begin{array}{c}0.017 \\
(0.012)\end{array}$ \\
\hline \multicolumn{3}{|l|}{ Wealth Index: Lowest } \\
\hline Lower & $\begin{array}{l}-0.006 \\
(0.024)\end{array}$ & \\
\hline Middle & $\begin{array}{l}-0.006 \\
(0.024)\end{array}$ & \\
\hline Rich & $\begin{array}{l}-0.045^{*} \\
(0.025)\end{array}$ & \\
\hline Richest & $\begin{array}{l}-0.147^{* * *} \\
(0.028)\end{array}$ & \\
\hline Months Since Birth & $\begin{array}{l}-0.009 * * * \\
(0.001)\end{array}$ & $\begin{array}{c}0.019 \\
(0.016)\end{array}$ \\
\hline \multicolumn{3}{|l|}{ Multiple Birth: Singleton } \\
\hline First of Multiple & $\begin{array}{l}0.023^{*} \\
(0.013)\end{array}$ & $\begin{array}{c}0.094^{* * *} \\
(0.030)\end{array}$ \\
\hline Second of Multiple & $\begin{array}{l}0.025 * * \\
(0.012)\end{array}$ & $\begin{array}{c}0.025 \\
(0.030)\end{array}$ \\
\hline Third of Multiple & $\begin{array}{l}0.230 * * \\
(0.091)\end{array}$ & $\begin{array}{c}0.142 \\
(0.124)\end{array}$ \\
\hline \multicolumn{3}{|l|}{ Fourth of Multiple } \\
\hline \multicolumn{3}{|l|}{ Month of Birth: January } \\
\hline February & $\begin{array}{c}0.003 \\
(0.007)\end{array}$ & $\begin{array}{c}0.026 \\
(0.022)\end{array}$ \\
\hline March & $\begin{array}{l}-0.002 \\
(0.007)\end{array}$ & $\begin{array}{c}0.057 \\
(0.035)\end{array}$ \\
\hline April & $\begin{array}{l}-0.001 \\
(0.008)\end{array}$ & $\begin{array}{c}0.066 \\
(0.050)\end{array}$ \\
\hline May & $\begin{array}{l}-0.003 \\
(0.008)\end{array}$ & $\begin{array}{c}0.104 \\
(0.065)\end{array}$ \\
\hline June & $\begin{array}{l}-0.002 \\
(0.008)\end{array}$ & $\begin{array}{c}0.115 \\
(0.081)\end{array}$ \\
\hline July & $\begin{array}{l}-0.014 \\
(0.009)\end{array}$ & $\begin{array}{c}0.126 \\
(0.097)\end{array}$ \\
\hline August & $\begin{array}{c}-0.020 * * \\
(0.010)\end{array}$ & $\begin{array}{c}0.175 \\
(0.112)\end{array}$ \\
\hline September & $\begin{array}{c}-0.031 * * * \\
(0.010)\end{array}$ & $\begin{array}{c}0.186 \\
(0.128)\end{array}$ \\
\hline October & $\begin{array}{c}-0.023 * * \\
(0.011)\end{array}$ & $\begin{array}{c}0.226 \\
(0.144)\end{array}$ \\
\hline November & $\begin{array}{c}-0.024^{* *} \\
(0.012)\end{array}$ & $\begin{array}{c}0.221 \\
(0.160)\end{array}$ \\
\hline December & $\begin{array}{l}-0.023^{*} \\
(0.013)\end{array}$ & $\begin{array}{c}0.242 \\
(0.176)\end{array}$ \\
\hline Female & $\begin{array}{c}-0.028^{* * *} \\
(0.003)\end{array}$ & $\begin{array}{c}-0.025 * * * \\
(0.006)\end{array}$ \\
\hline Place of Birth: Own Home & & \\
\hline Other Home & $\begin{array}{l}-0.010 \\
(0.012)\end{array}$ & $\begin{array}{l}-0.059 \\
(0.036)\end{array}$ \\
\hline Government Hospital & $\begin{array}{l}-0.015^{* * *} \\
(0.006)\end{array}$ & $\begin{array}{l}-0.015 \\
(0.019)\end{array}$ \\
\hline Government Clinic & $\begin{array}{l}-0.007 \\
(0.006)\end{array}$ & $\begin{array}{l}-0.015 \\
(0.020)\end{array}$ \\
\hline Private Hospital or Clinic & $\begin{array}{l}-0.019 * * * \\
(0.007)\end{array}$ & $\begin{array}{l}-0.016 \\
(0.023)\end{array}$ \\
\hline Other & $\begin{array}{l}-0.030 \\
(0.019)\end{array}$ & $\begin{array}{l}-0.035 \\
(0.055)\end{array}$ \\
\hline Missing & $\begin{array}{c}0.009 \\
(0.039)\end{array}$ & $\begin{array}{c}0.243 \\
(0.149)\end{array}$ \\
\hline Birth Interval: 1st & & \\
\hline 1-11 Months & $\begin{array}{c}0.042^{* *} \\
(0.020)\end{array}$ & $\begin{array}{c}0.010 \\
(0.036)\end{array}$ \\
\hline 12-17 Months & $\begin{array}{c}0.037 * * * \\
(0.009)\end{array}$ & $\begin{array}{c}0.023 \\
(0.015)\end{array}$ \\
\hline 18-23 Months & $\begin{array}{l}0.037 * * * \\
(0.008)\end{array}$ & $\begin{array}{l}0.025^{*} \\
(0.013)\end{array}$ \\
\hline $24+$ Months & $\begin{array}{l}0.020^{* * *} \\
(0.007)\end{array}$ & $\begin{array}{c}0.030^{* * *} \\
(0.010)\end{array}$ \\
\hline $\begin{array}{l}\text { Birth History: 1st } \\
2\end{array}$ & 0.000 & \\
\hline
\end{tabular}


Anaemia

\begin{tabular}{|c|c|c|}
\hline Variables & OLS Full Sample & Sibling IV FE \\
\hline & $(0.007)$ & \\
\hline 3 & 0.004 & \\
\hline & $(0.009)$ & \\
\hline 4 & 0.012 & \\
\hline & $(0.010)$ & \\
\hline 5 & $0.024^{* *}$ & \\
\hline & $(0.010)$ & \\
\hline Birth Order: 1st & & \\
\hline 2 & 0.015 & $-0.129 * * *$ \\
\hline & $(0.014)$ & $(0.040)$ \\
\hline 3 & 0.008 & $-0.172^{* * *}$ \\
\hline & $(0.017)$ & $(0.049)$ \\
\hline 4 & 0.039 & -0.097 \\
\hline & $(0.046)$ & $(0.079)$ \\
\hline 5 & 0.157 & -0.262 \\
\hline & $(0.148)$ & $(0.210)$ \\
\hline Mother's Age: 15-19 & & \\
\hline $20-24$ & $\begin{array}{c}-0.025 * * * \\
(0.007)\end{array}$ & \\
\hline $25-29$ & $\begin{array}{c}-0.043^{* * *} \\
(0.008)\end{array}$ & \\
\hline $30-34$ & $\begin{array}{c}-0.055^{* * *} \\
(0.009)\end{array}$ & \\
\hline $35-39$ & $\begin{array}{c}-0.060 * * * \\
(0.010)\end{array}$ & \\
\hline $40-44$ & $\begin{array}{c}-0.075^{* * *} \\
(0.011)\end{array}$ & \\
\hline $45-49$ & $\begin{array}{c}-0.104^{* * *} \\
(0.016)\end{array}$ & \\
\hline Rural & $\begin{array}{c}0.002 \\
(0.005)\end{array}$ & \\
\hline Mother's Education: None & & \\
\hline Primary & $\begin{array}{c}-0.022 * * * \\
(0.005)\end{array}$ & \\
\hline Secondary & $\begin{array}{c}-0.031 * * * \\
(0.006)\end{array}$ & \\
\hline Tertiary & $\begin{array}{c}-0.059^{* * *} \\
(0.009)\end{array}$ & \\
\hline Don't Know/Missing & & \\
\hline Toilet in House: No & & \\
\hline Yes & $\begin{array}{l}-0.001 \\
(0.006)\end{array}$ & \\
\hline Missing & $\begin{array}{c}0.012 \\
(0.019)\end{array}$ & \\
\hline Water in House: No & & \\
\hline Yes & $\begin{array}{c}0.001 \\
(0.004)\end{array}$ & \\
\hline Missing & $\begin{array}{c}-0.043^{* *} \\
(0.020)\end{array}$ & \\
\hline Partner's Education: None & & \\
\hline Primary & $\begin{array}{c}-0.016 * * * \\
(0.005)\end{array}$ & \\
\hline Secondary & $\begin{array}{c}-0.024 * * * \\
(0.006)\end{array}$ & \\
\hline Tertiary & $\begin{array}{c}-0.045 * * * \\
(0.008)\end{array}$ & \\
\hline Don't Know/Missing & $\begin{array}{c}-0.023^{* *} \\
(0.010)\end{array}$ & \\
\hline Marital Status: Never Married & & \\
\hline Married & $\begin{array}{c}-0.031^{* *} \\
(0.013)\end{array}$ & \\
\hline Living Together & $\begin{array}{l}-0.012 \\
(0.013)\end{array}$ & \\
\hline Widowed & $\begin{array}{c}-0.031 * \\
(0.018)\end{array}$ & \\
\hline Divorced & $\begin{array}{c}0.003 \\
(0.018)\end{array}$ & \\
\hline Not Living Together & $\begin{array}{c}0.002 \\
(0.015)\end{array}$ & \\
\hline Religion: Christian & & \\
\hline Muslim & $\begin{array}{c}0.044^{* * *} \\
(0.007)\end{array}$ & \\
\hline Jewish & $\begin{array}{c}0.059 * * \\
(0.027)\end{array}$ & \\
\hline Buddhist & $\begin{array}{c}0.034 \\
(0.024)\end{array}$ & \\
\hline
\end{tabular}




\section{Anaemia}

\begin{tabular}{|c|c|c|}
\hline Variables & OLS Full Sample & Sibling IV FE \\
\hline Hindu & $\begin{array}{c}0.073^{* * *} \\
(0.011)\end{array}$ & \\
\hline Sikh & $\begin{array}{c}0.126^{* * *} \\
(0.027)\end{array}$ & \\
\hline Traditional & $\begin{array}{l}0.025^{*} \\
(0.013)\end{array}$ & \\
\hline Other & $\begin{array}{c}0.006 \\
(0.014)\end{array}$ & \\
\hline None & $\begin{array}{c}0.004 \\
(0.013)\end{array}$ & \\
\hline Unknown & $\begin{array}{c}-0.065^{* * *} \\
(0.021)\end{array}$ & \\
\hline Maternal Tetanus Injection: Yes & & \\
\hline None & $\begin{array}{c}0.001 \\
(0.005)\end{array}$ & $\begin{array}{l}-0.020 \\
(0.012)\end{array}$ \\
\hline Missing & $\begin{array}{l}-0.008 \\
(0.009)\end{array}$ & $\begin{array}{l}-0.018 \\
(0.027)\end{array}$ \\
\hline Wanted Birth: Before & & \\
\hline Later & $\begin{array}{c}-0.003 \\
(0.004)\end{array}$ & $\begin{array}{l}-0.002 \\
(0.010)\end{array}$ \\
\hline No More & $\begin{array}{c}0.014^{* *} \\
(0.005)\end{array}$ & $\begin{array}{l}-0.000 \\
(0.015)\end{array}$ \\
\hline Don't Know/Missing & $\begin{array}{l}-0.050 \\
(0.073)\end{array}$ & $\begin{array}{l}-0.039 \\
(0.138)\end{array}$ \\
\hline Antenatal Visit: No & & \\
\hline Yes & $\begin{array}{l}-0.011 \\
(0.010)\end{array}$ & $\begin{array}{l}-0.022 \\
(0.025)\end{array}$ \\
\hline Missing & $\begin{array}{l}-0.016 \\
(0.015)\end{array}$ & $\begin{array}{c}0.043 \\
(0.042)\end{array}$ \\
\hline Constant & $\begin{array}{c}134.044^{* * *} \\
(12.892)\end{array}$ & $\begin{array}{c}18.161 \\
(20.211)\end{array}$ \\
\hline Observations & 104,845 & 48,267 \\
\hline
\end{tabular}

Note: Birth weight coefficients are multiplied by 1000. Models using observations with birth weight data are shown. Where they are not part of the fixed effect, the models include controls for year of birth fixed effects, survey year fixed effects, country specific year of birth trends, country specific wealth index quintile and country fixed effects, which are not shown in the table. Standard errors in the OLS model are adjusted for clustering at the household level. 